\title{
Depression screening and psychological intervention in pregnancy care and their relationship with complications during pregnancy
}

\author{
$\mathrm{PhD}$ Thesis
}

Emőke Adrienn Hompoth

Supervisor:

Annamária Töreki, $\mathrm{PhD}$

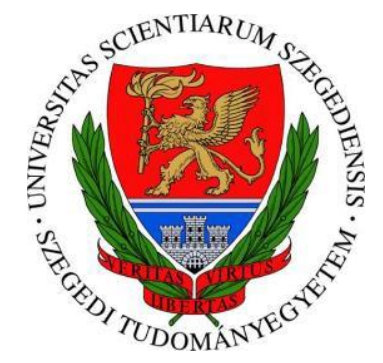

Doctoral School of Clinical Medicine

Department of Emergency Medicine

University of Szeged, Hungary

2020 
List of publications providing the basis and related to the topic of the thesis

I. Hompoth EA, Pető Z, Fürészné Balogh V, Töreki A. Associations Between Depression Symptoms, Psychological Intervention and Perinatal Complications. J Clin Psychol Med Settings. 2020;27(1): 199-205.

IF: $1.477(2018)$

II. Hompoth EA, Gálosi N, Becsei L, Töreki A. Pszichológiai szürés a várandósgondozásban: eredmények Békéscsaba körzetéből [Psychological screening in the pregnancy care: results from the area of Békéscsaba]. Orv Hetil. 2020;161(10): 380-7.

IF: $0.564(2018)$

III. Hompoth EA, Töreki A, Baloghné Fürész V, Németh G. A hangulati állapot alakulásának kockázati tényezői a perinatalis időszakban | The risk factors of mood changing during the perinatal period. Orv Hetil. 2017;158: 139-46.

IF: 0.322 (2017) 
Table of content

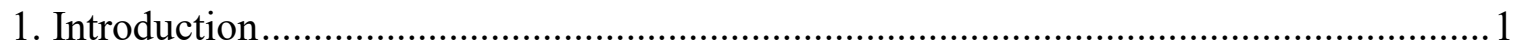

1.1 Changes during pregnancy and their impact on women's lives............................. 1

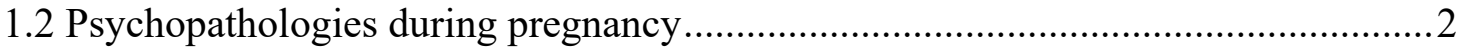

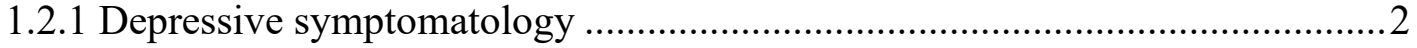

1.2.2 Prevalence of antenatal and postnatal depression ..........................................

1.2.3 Risk and protective factors of antenatal and postnatal depression ...................4

1.2.4 Untreated or undertreated depression and complications................................ 4

1.2.5 Previous studies about psychological interventions .....................................5

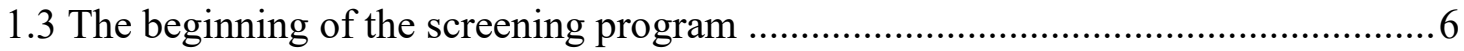

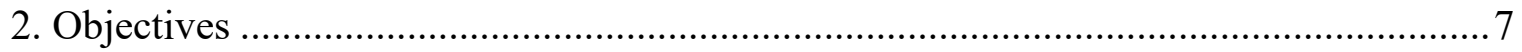

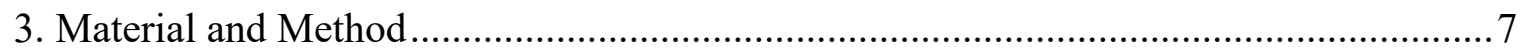

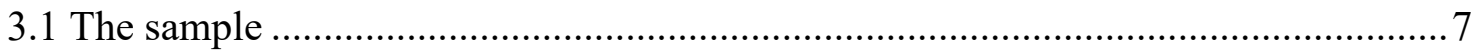

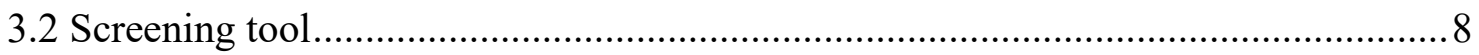

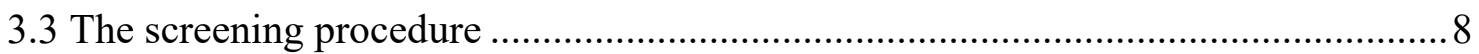

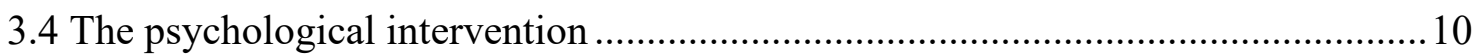

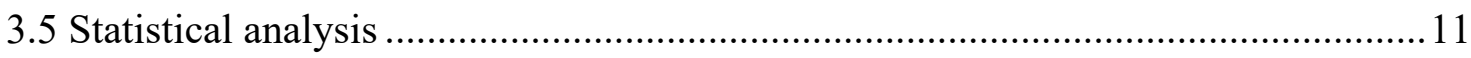

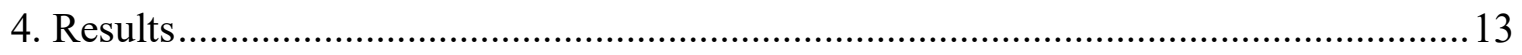

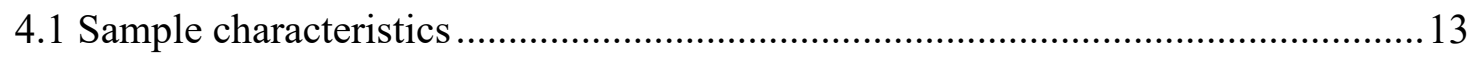

4.2 Assessment of depressive scores and pathologic rate ........................................ 15

4.3 Relation between the antepartum and the postpartum EPDS scores...................... 17

4.4 Features of the intervention, participation rate, EPDS scores ............................... 19

4.5 EPDS scores and pre- and peripartum complications ........................................20

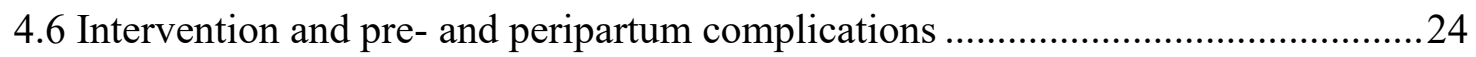

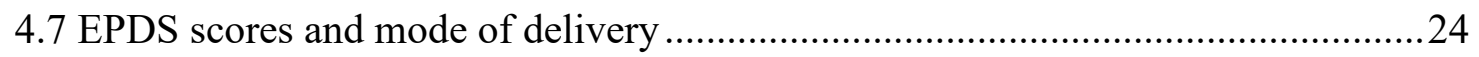

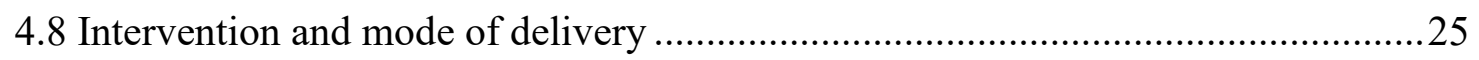

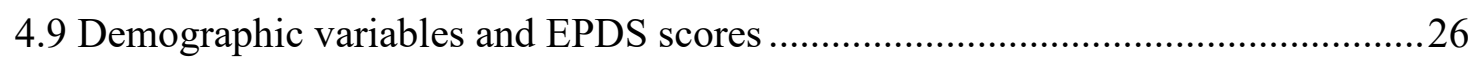

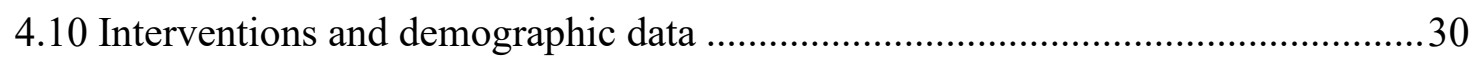

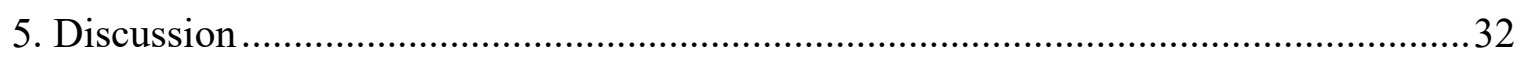

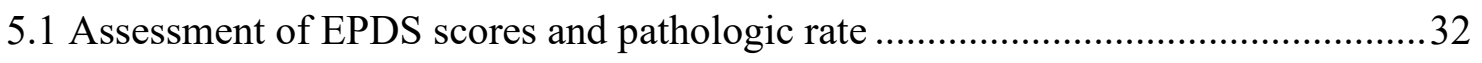

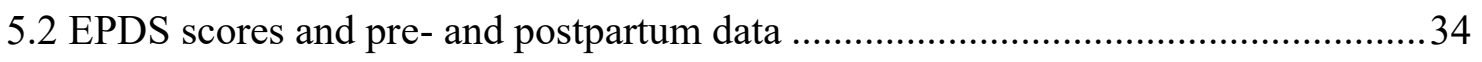

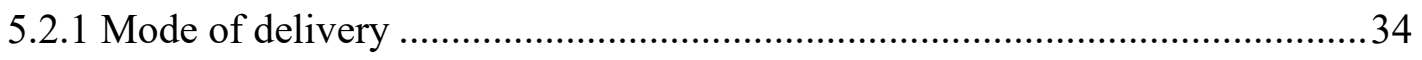

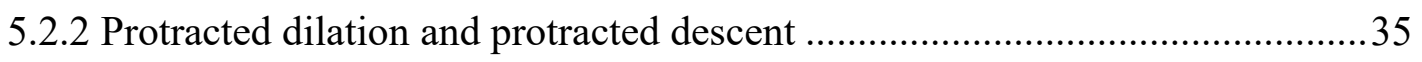

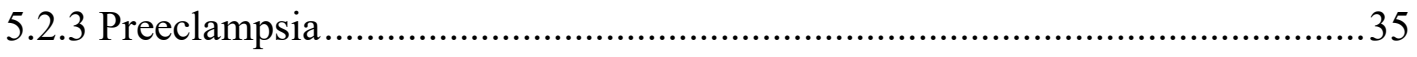


5.2.4 Intrauterine growth restriction

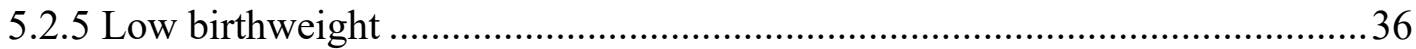

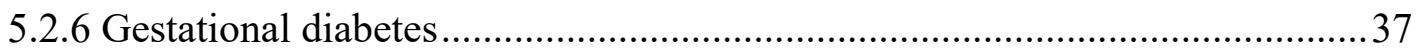

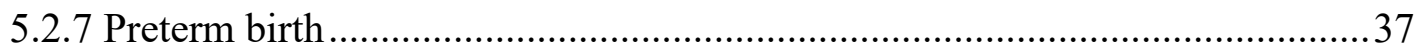

5.3 Relation between the antepartum and the postpartum EPDS scores........................38

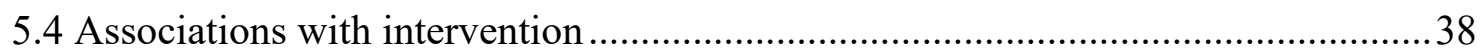

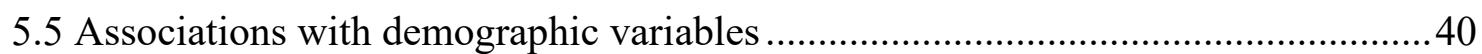

5.6 Other approaches, further research possibilities ................................................... 41

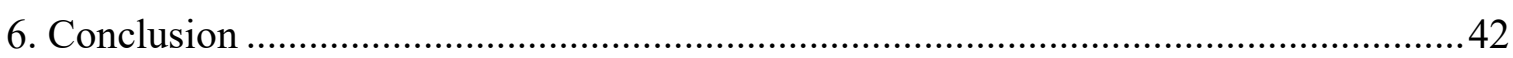

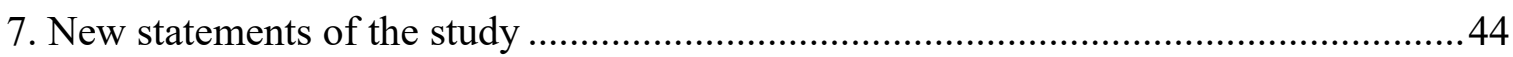

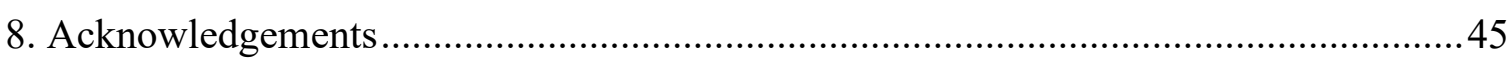

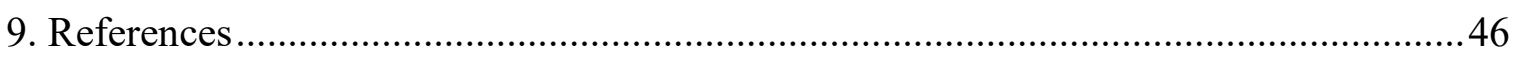

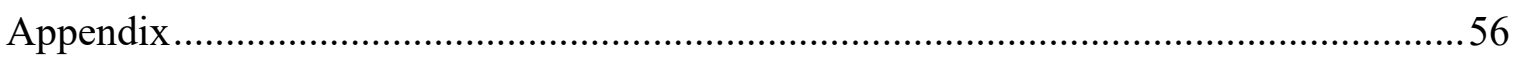

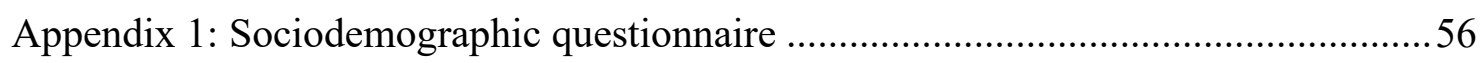

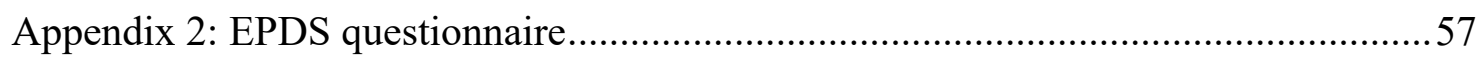

Publications providing the basis and related to the topic of the thesis ..............................59 


\section{Depression screening and psychological intervention in pregnancy care and their impact on complications during pregnancy}

\section{Introduction}

Pregnancy is a milestone in women's life: usually it is desired by women to have at least one child to experience the feeling of being a mother and to extend as a family. However, during this time women can have countless questions and pregnancy can cause psychological difficulties too, thus women can feel overwhelmed and become depressed or stressed out. Most of the times these feelings are in a normal range and do not cause further problems, as women can cope with them, but sometimes these feelings and insecurity can be so intense that psychopathology arise. In these cases, it is important that women should be provided more attention and special treatment. To do so, we need a tool to identify the affected women and a qualified staff to help the women deal with their symptoms.

In Szeged, a fully operational program exists aiming these tasks: perinatal nurses screen out the affected women by using a screening tool and psychologists help them overcome the difficulties. In this thesis, I will describe this program and present the statistical results on the pre- and peripartum complications.

\subsection{Changes during pregnancy and their impact on women's lives}

During pregnancy women's lives are impacted by many changes concerning their lifestyle, priorities, financial status, their roles in the family etc. Pregnant women have to face various hardships. In the first trimester, morning sickness, anhedonia [1] and the fear from spontaneous abortion can happen to women [2]. The second trimester is usually more relaxed, normally the morning sickness is gone, women can feel the motion of the fetus which helps to form the bond between them. In the third trimester, women can be anxious and fearful when thinking about childbearing and the pain triggered by it, besides, the increased size of the belly can make it very difficult to do the everyday tasks or even to sleep [3]. In the postpartum period, many women are concerned about their children and their role as a mother: Do they feed their children well? Do their children grow at a normal pace? Also, they can become anxious about the possibility of their worsening financial status. anxiety can occur concerning the worsening of their existential status [4]. 
The above-mentioned difficulties can become so overwhelming that psychopathological symptoms can appear, which can affect the development of the fetus and lead to being vulnerable to some diseases later [5].

\subsection{Psychopathologies during pregnancy}

There are some disorders, which arise quite often during pregnancy and after delivery. By their main characteristics they can be sorted into two groups: anxiety disorders and mood disorders. According to the sources of special literature, the prevalence of anxiety disorders among pregnant women are $4-39 \%$ [6] and $16 \%$ in the postpartum period [7]. In a Hungarian sample $14.6 \%$ of women showed anxiety symptoms in the first trimester, and $4.2 \%$ of them had serious anxiety [8]. During pregnancy the following anxiety disorders can develop: panic disorder, generalized anxiety disorder, obsessive-compulsive disorder, agora-, social- and specific phobias and posttraumatic stress disorder [6].

Mood disorders are classified as maternity blues, depression and postpartum psychosis [9]. Maternity blues is such a common condition, it can almost be regarded as normal [10], as its prevalence is $50-80 \%$ [11]. The symptoms usually begin a few days after delivery, they are at the peak on the fifth day, and last up to ten days. The symptoms can be weeping, mood lability, irritability, fatigue and anxiety. If the symptoms last longer than ten days, it might be a sign of early onset depression, thus the patient should be evaluated to rule out its possibility $[12,13]$. Although the two have similar characteristics, maternity blues should not be confused with the more serious, protracted perinatal depression [10]. The most serious phenomenon is the postpartum psychosis, which occurs in $0.1-0.2 \%$ of women, mostly on the first week after childbirth. It needs immediate medical treatment, mostly hospitalization, as it can have additional symptoms including hallucinations, delusions, apathy, thus can be a threat both to the mother and her child [14].

\subsubsection{Depressive symptomatology}

The criteria of depression according to the DSM-IV diagnostic system are the following: a) depressed mood or loss of interest in everyday activities, lasting at least for two consecutive weeks, b) mood worsening compared to the pre-episode status, c) clinically significant impairment or distress in social, occupational, or educational functioning (or normal functioning, but it requires considerably increased effort), d) specific symptoms, 
from which at least five are present nearly every day for most of the day. These symptoms are the following: 1) depressive mood or irritability, which can be a subjective feeling, like feeling herself sad or empty; or it can be observed by others, like seeing her cry, 2) decreased interest or feeling of pleasure (anhedonia) concerning most of the activities, 3) significant change in weight (5\%) or appetite, 4 ) sleep changes (insomnia or increased need of sleep), 5) changes in psychomotor activity (agitation or retardation), 6) exhaustion, fatigue, decreased energy, 7) excessive feeling of worthlessness or guilt, or not appropriate for the situation, 8) hardship in thinking, concentrating, or making decisions, 9) recurring thoughts of death, suicidal ideations, having suicidal plans [15].

\subsubsection{Prevalence of antenatal and postnatal depression}

Gaynes et al. [16] wrote in their meta-analysis that $11 \%$ of pregnant women experience minor or major depression in the first trimester, $8.5 \%$ in the second and third trimester and $9.7 \%$ in the postpartum period. From the depressed women $18 \%$ seeks psychological help in the antepartum period and $40 \%$ in the postpartum period $[17,18]$.

In Hungary, only a few studies have focused on antenatal and postnatal depression, thus no accurate information is available about its prevalence in the entire population [19]. As part of the Hungarostudy, which was a comprehensive and representative study, Kopp et al. [20] aimed to measure the incidence of depressive symptoms in the Hungarian society. According to the findings, the prevalence of depression among women increased between 1988 and 1995 from $25.8 \%$ to $33.3 \%$ and the prevalence of serious depression increased from 3\% to 7.7\% [20]. Further increase was observed between 2002 and 2006 regarding the prevalence of serious depressive symptoms: from $10.7 \%$ to $14.2 \%$ [21]. It is important to note that these findings were the results of all the women, not just the pregnant or the postpartum women.

There are some Hungarian studies which have studied the antenatal and postnatal depression in smaller areas. Bödecs [19] used the 9-item version of the Beck Depression Inventory (in [19] referring to [20]) and observed that $17.9 \%$ of women had depressive symptoms in the antenatal phase, from them 1\% showed serious symptoms in Szombathely. Töreki et al. [24] used the validated [25,26] Edinburgh Postnatal Depression Scale [27] and found that $9.3 \%, 12.8 \%, 9.3 \%$ and $17.5 \%$ of women showed depressive symptoms at a pathological level in the first, second, third trimester and postpartum phase in Békéscsaba in 2014. Five years later the following pathologic rate appeared: $15.31 \%, 14.29 \%$ and 
$11.87 \%$ during pregnancy, and 12.68\% after childbirth [28]. In Szeged, with the same screening method, another pathological rate came into sight in $2014: 12 \%, 6 \%, 6.4 \%$ and $8.2 \%$ in the first, second, third trimester and postpartum phase [24]. Two years later, studying a broader spectrum, similar pathological rate appeared: $10.8 \%$ in the first trimester, $6.9 \%$ and $6.5 \%$ in the second and third trimester and $7.8 \%$ in the postpartum period [29].

\subsubsection{Risk and protective factors of antenatal and postnatal depression}

There are some factors which were connected to depression in the antenatal and postnatal period, including non-planned pregnancy [28-32], young age [19,28,29,32,33] or being older than 34 years old [29], being single or widowed [28-30,33], anxiety disorders [6] and psychological abuse coming from the husband [34]. As reported by Leigh and Milgrom [35] antepartum depression was a strong predictor for postpartum depression.

Protective factors seem to be primiparity [29,30], family support, patient attitude of the family and friends [3] and even epidural analgesia can have beneficial effect on postpartum depression [36], probably because of its impact on easing pain and the feeling of fatigue. Pain during childbirth has already been linked to postpartum mood disorders like maternity blues and EPDS scores [37].

\subsubsection{Untreated or undertreated depression and complications}

Many studies have found that pre- and postpartum depression is associated with pre- and peripartum complications. According to Chung et al. [38], depression in the late stage of pregnancy increased the risk of epidural analgesia, caesarean sections and instrumental vaginal deliveries, moreover, increased risk was observed for preeclampsia [39], and gestational diabetes [40]. It was also found, that women with perinatal depression were less likely to attend to pregnancy care, they were more likely to take drugs, smoke or consume alcohol and they didn't gain enough weight as they were more malnourished [41].

Not only is the mother affected by perinatal depression; but it can also have some effect on the fetus, the newborn and even on the adult descendants as well. Beforehand, it has been found that perinatal depression is related to premature birth [42] and, paradoxically, with prolonged pregnancy [43]. Besides, it is associated with intrauterine growth restriction [44] and low birthweight $[29,45]$. Maternal depression in the late stage of pregnancy also 
increased the probability of the necessity for the admission to neonatal care unit after childbirth [38].

Perinatal depression can affect the mother-infant bond, relationship as well: RighettiVeltema et al. [46] observed that depressed mothers smiled less and used less vocal and visual communication and corporal interactions. Moreover, as stated by HübnerLiebermann et al. [47], among these mothers, obsessive thoughts or impulses about harming the child were not rare.

Maternal depression and the probable complications mentioned above can have further effects: according to earlier studies depressed mothers' children had feeding and sleeping problems [48], and showed decreased cognitive and fine motor development [49]. Hays et al. [50] found that adolescents from mothers, who suffered from postpartum depression, had lower IQ compared to adolescents of non-depressed mothers. Furthermore, reported by Pawlby et al. [51], maternal antepartum depression increased the probability by 4.7 of the descendants being depressed when they were sixteen years old.

As we can see, maternal pre- and postpartum depression can have negative effects on both the mother and her child in the short and in the long run. Thus, providing intervention and treatment seems to be essential.

\subsubsection{Previous studies about psychological interventions}

According to Hübner-Liebermann et al. [47] treatment of perinatal depression can occur on different levels: the base of it is psychoeducation with the inclusion of relatives, psychotherapy and psychopharmacology.

There is a debate over psychopharmacological treatment, whether the use of it is acceptable or not, because certain ingredients of all antidepressants cross the placenta and it can be detected in breastmilk as well, according to studies [52]. Pregnant women and nursing mothers usually worry about the side effects of these medications. Most studies have been conducted on tricyclic antidepressants and selective serotonin reuptake inhibitors. As stated by the results some of these can be used at small risk, while others showed teratogenous effect, but even in the first case we must take into consideration the side effects. This makes previous consultation and follow up even more important. It is usually suggested using only one type of medication at once, because combining them could lead to unexpected side effects, and start taking it at a low dose and increasing the dosage if needed is also recommended. It is crucial to talk about breastfeeding prior medical treatment, because 
some drugs should be avoided if somebody wants to breastfeed her baby. It is also important to help women in decision-making, because depression can alter their judgmental skills [47,52-54]. Taking into consideration that antidepressants might have teratogenous effect and untreated depression is also a risk factor for unwanted complications, it is essential that doctors help women think over the risks of the sudden discontinuation of the medical treatment over the potential risks of continuing the treatment [55].

Psychological interventions and their effects have also been studied: Milgrom et al. [56] provided phone interventions weekly in the antenatal period, focusing on enhancing problem solving skills, feeling of competence and decreasing risk factors. The results have shown that women who took part in this intervention, have significantly fewer depressive and anxiety symptoms in the postpartum phase compared to women who have not taken part in it.

According to Dennis and Hodnett's review [57], both psychosocial and psychological interventions helped preventing or treating postpartum depression including frequent home visits by nurses, supportive talks on the phone and interpersonal therapies. In the focus of the last one was women's role changes, losing relationships, debates with partner or other family members and grief after previous perinatal losses or after the loss of a significant person [58].

Cognitive behavior approach also seemed to be effective as reported by O'Mahen et al., [59]: using this method they could help women in managing social support and reducing excessive self-sacrifice and automatic negative thoughts. The cost-effective music therapy helped reducing stress, depressive symptoms and anxiety [60], while psychoeducation with relaxation techniques helped reducing severe fear of childbirth, thus women tended to choose vaginal delivery instead of elective cesarean section [61].

\subsection{The beginning of the screening program}

As the prevalence of pre- and postpartum depression is high, it has many risk factors and many complications can be connected to both in the mother's and her descendant's lives, it is important to have a pre- and postpartum screening program to identify the women who are more likely to have these outcomes. Of course, there are some concerns about these programs, for example, stigma of mental illness can be a barrier in the way of an effective program and women who are screened out can underestimate themselves [62]. However, ignoring mental illness will not help overcome it: it is better to identify depression and 
distress with a screening program and offer interventions, than to refuse their existence and allow them to affect women's lives and lead to long term problems [63].

To start the screening program, a short, easily administrable questionnaire was needed. The Edinburgh Postnatal Depression Scale (EPDS) [25-27] was chosen for this purpose, as it is the most widely used tool to measure perinatal depression [64]. The EPDS was validated in Hungary on antepartum and postpartum samples between 2010 and 2011 by Töreki et al. $[25,26]$. The screening procedure started on April 2011 and it has become part of pregnancy care since.

For the last couple of years this program has been introduced in Cegléd, Békéscsaba and Vác too. Due to our information in Békéscsaba the program is fully operational; in Vác perinatal nurses screen women only in the first trimester; and in Cegléd women are screened only if nurses feel the necessity of it.

\section{Objectives}

Our aim was to observe if depressive scores are related to pre- and peripartum complications on the Hungarian sample as well, just like in the literature. Although we did not find any source in the literature that had studied the connection between depressive scores and protracted cervical dilation and protracted descent, we think there might be an association between them, thus we added these outcomes to the list of complications. Besides we wanted to assess pathological rate in our sample, investigate how depressive scores varied during pregnancy and after delivery, and how demographic variables were connected to the depressive scores. We also wanted to study how psychological intervention was related to pre- and peripartum complications, depressive scores and demographic data.

\section{Material and Method}

\subsection{The sample}

Those women participated in the screening program, who attended to the pregnancy care of Szeged and its agglomeration. The participation in the screening was voluntary, the only excluding criteria was if somebody did not speak the Hungarian language fluently or who was underage. Although women could decide freely if they wanted to take part in the 
screening, the program still became part of pregnancy care: in the beginning the participation rate was around $30 \%$, but approximately two years ago about $90 \%$ of women filled in the screening tool at least once during pregnancy or in the postpartum phase. Between April 2011 and May 20174593 women participated in the screening program.

For one and a half year I have collected the obstetric data for 2118 women. Using their data, we excluded 26 women, who had twins, because twin pregnancies had already been associated with some obstetric outcomes like low birthweight [65], gestational diabetes [66] and preterm birth [67]. Besides we excluded 50 women who had procured or spontaneous abortion, or who had stillbirth, thus, in the end 2042 women were in the sample. We carried out the statistical analyses on the data of these women.

\subsection{Screening tool}

We used a sociodemographic questionnaire (Appendix 1) and the EPDS questionnaire (Appendix 2), which is a short screening tool: it has ten items, which are about the mood status of the previous week. For each question there are four possible answers, which can be scored from 0 to 3 points. In all, the whole questionnaire can be scored from 0 to 30 points. The $10^{\text {th }}$ question is also mentionable, as it measures suicidal tendency: women have to check how often they think about harming themselves [68].

The used cut-off scores for the likelihood of minor and major depression are 6/7 and 8/9 points in the antepartum period and $7 / 8$ and $12 / 13$ points in the postpartum phase $[25,26]$. In all cases, or if a woman showed any suicidal ideation, she was suggested to visit the psychologist of the Obstetric Clinic in Szeged. It is important to note that consultation with the psychologist was optional, anybody could decide not to do so; what is essential that from now on women know where they can ask for help if they feel the need of it [68]. It is also mentionable that this tool is a screening tool, not a diagnostic one. The terms "depression" or "depressed" are only used for the better understanding. We do not want to imply that these women were diagnosed by us as having a clinical disorder [68].

\subsection{The screening procedure}

In Hungary, a special group of health care workers is present in pregnancy care: perinatal nurses, who, to our knowledge, cannot be found in other countries. Perinatal nurses meet pregnant women in their first trimester, then follow up the whole pregnancy and even after the child is born [69]. 
Perinatal nurses take part in the primary care, their main tasks are preservation and enhancement of women's and their fetuses' health, early recognition of symptoms, disorders and complications, directing affected women to the right clinic and giving specific life management suggestions, including enhancing living conditions. They have an intimate relationship with pregnant women and help them prepare for the changes in their bodies during pregnancy, and to prepare for the childbirth and lactation psychosomatically. Perinatal nurses also have a part in positive family planning. They do family visits, during which they observe the environment, the conditions and potential threatening factors. They educate women, their spouses and their families what the most important tasks are after the child is born, how they can feed the newborn (lactation or other possibilities) and how to pick up, hold, clothe, bath, so take care of the baby. Perinatal nurses even have a role in perceiving if the baby is in threat in any way. They also have to pay attention to the new mother's mood status looking for signs of postpartum depression [69].

As perinatal nurses have a close relationship with pregnant and postpartum women, they were included in the screening program. They had a training how to fill in and evaluate the questionnaire at the beginning of the screening program and have got consultation sessions ever since.

When women met perinatal nurses for the first time, the nurses explained the aim of the screening, they collected the informed consent, the demographic data and the first EPDS questionnaire. Then three more times, so once in the second trimester, once in the third trimester and once in the postpartum phase, the nurses collected the EPDS questionnaire again. Not all women filled in all four EPDS questionnaires, as some women moved to Szeged in the second or third trimester, or even after childbirth; other women moved away during their pregnancies; some were hospitalized, therefore did not visit the perinatal nurse at that time and so on.

The perinatal nurses evaluated the questionnaires and advised women with pathological scores to contact the psychologist. Then the nurses collected the questionnaires and sent them to the psychologist of the Obstetric Clinic, who then registered the data into the patient record system.

In many cases women had their first perinatal nurse visit after the genetic ultrasound evaluation on the $12^{\text {th }}$ week, thus these women had their first EPDS tests on the $13-14^{\text {th }}$ week. While many of them had other EPDS scores from the second trimester, we categorized EPDS tests from weeks 13 and 14 to be in the first trimester. EPDS tests from 
week 15 to 30 were listed to the second trimester and data from week 31 or higher were enrolled to the third trimester.

The original study procedure was approved by the Regional Human Biomedical Research Ethics Committee of University of Szeged ed (100/2010 and 89/2011) and was carried out according to the Declaration of Helsinki and the Oviedo Convention. Since then the Hungarian Ministry of Human Resources [70] suggested perinatal nurses to pay attention to women's psychological state and depressive symptoms as well and use the EPDS questionnaire as a screening tool. In Szeged, the depression screening became part of pregnancy care.

\subsection{The psychological intervention}

All in all, 188 women participated in psychological intervention as part of the screening program. We collected their obstetric data and after excluding women with twins and women who had procured or spontaneous abortion or stillbirth, we had our intervention group with 150 women. Everybody else was in the non-intervention group [68].

During these interventions we, as health psychologists, studied the depressive symptoms more deeply: when their onset was, whether their intensity changed over time, how they affected women's everyday lives, whether women turned to anybody for support or help, etc. We did not predetermine the sessions, neither the focus nor the number of occasions: we focused on any problem women had relating their pregnancies and offered as many consultations as needed. Of course, if a woman seemed to need other kinds of help, like long therapy with a clinical psychologist or even medication, we helped finding the right professional and provided referral note to the Department of Psychiatry at University of Szeged [68].

With the interventions, our goals were to help women to increase and maintain healthy functioning and reduce depressive and anxiety symptoms. We used supportive techniques, reinforcement, psychoeducation, crisis intervention, reducing anxiety, hopelessness and depressive symptoms, relaxation techniques, assistance in coping with losses, enhancing coping skills and sense of control, relationship counseling and cognitive behavioral elements. We also offered help in enhancing communication skills, for example, how to ask their doctors or nurses for information or help. In the case of serious psychopathology or suicidal thoughts, women were directed to the Department of Psychiatry for further medical examination [68]. 


\subsection{Statistical analysis}

For statistical analysis we used the IBM SPSS Statistics version 22. The significance level was set to 0.05 . We created groups based on the EPDS scores, the different types of preand peripartum complications, mode of delivery, attendance at the interventions and demographic data [68].

Using the women's obstetric data, seven complication groups were created: 1) preterm birth (birth before the $36^{\text {th }}$ week), 2) protracted cervical dilation, 3) protracted descent, 4) preeclampsia, 5) gestational diabetes mellitus (GDM),6) intrauterine growth restriction (IUGR - diagnosis was given by the obstetrician) and 7) low birthweight (under 2500 grams). In the control group were the women, who did not have any of these complications Mode of delivery was divided into two groups: cesarean section (with emergency and elective cesarean section) and vaginal birth. Considering the intervention, the following way to create groups was made: women who attended the interventions constituted the intervention group and everybody else was in the non-intervention group [68].

To enhance the power of the analyses, we supplemented the missing data of the EPDS scores of the 2042 women, which is a statistically permissible method. To do so we calculated the median value of the EPDS scores for all measuring occasions separately for the following groups: 1) preterm birth (birth before the $36^{\text {th }}$ week), 2) protracted cervical dilation, 3) protracted descent, 4) preeclampsia, 5) GDM, 6) IUGR (diagnosis given by the obstetrician), 7) low birthweight (under 2500 grams), 8) women who had at least two of the above-mentioned complications and 9) women who had none of the above-mentioned complications. We used this method, because previous studies had found connections between most of these complications and depression; thus, calculating only one median value per measuring occasion could have distorted the results [68]. We supplemented 183 women's data in the first trimester, 405 and 647 women's data in the second and third trimester, and 904 women's data in the postpartum phase.

We used non-parametric tests in the statistical analyses because these methods do not require a normal distribution, thus they are more reliable when the variables are not normally distributed. Also, these tests do not require equal group sizes. These nonparametric tests transform the data (the EPDS scores) in their computations, and their results are mean ranks (instead of EPDS score means). These results are a little harder to interpret, as they cannot be directly compared to the EPDS scores, although higher mean ranks refer to more depression symptoms, just like higher EPDS scores [68]. 
We used Friedman's test to analyze if EPDS mean ranks stay stable or change over time, as pregnancy proceeds and after the child is born. Mann-Whitney $\mathrm{U}$ tests with Bonferroni corrections were used to explore if EPDS mean ranks were connected to the following preand peripartum complications: preeclampsia, GDM, IUGR, preterm birth, low birthweight, protracted cervical dilation and protracted descent. Mann-Whitney $U$ test was used to see if there was any connection between the EPDS mean ranks and mode of delivery [68].

We used Kruskal-Wallis test with pairwise comparisons to analyze whether there was any difference in the EPDS mean ranks between women who started the intervention in different trimesters or did not attend at all. The following grouping was used: 0 - did not ask for psychological intervention, 1 - came in the first trimester, 2 - came in the second trimester, 3 - came in the third trimester and 4 - came in the postpartum period [68].

We used Pearson's Chi-square tests to analyze whether there was any connection between intervention and the following pre- and peripartum complications: preeclampsia, GDM, IUGR, preterm birth, low birthweight, protracted cervical dilation and protracted descent. We used the same method to determine whether there was a relationship between mode of delivery and intervention [68].

Pearson Correlation was used to analyze whether there was a relationship between EPDS scores of all measuring occasions. Using Mann-Whitney U tests and Kurskal-Wallis test with Bonferroni correction we determined whether EPDS mean ranks were connected to demographic variable such as age, marital status, number of children and planning of pregnancy. We used Pearson Chi-square tests to analyze whether intervention was connected to marital status, parity and planned pregnancy.

We used the non-supplemented EPDS scores for three analyses. In the first one we wanted to explore pathological rate. To do so we created "depressive" and "non-depressive" groups based on women's EPDS scores and the cut-off scores. Then we conducted the Frequencies analysis on these groups in all trimesters and in the postpartum phase [68]. We also explored how many women had pathological scores at least once during the whole antepartum phase. Then, in the third analysis we used Wilcoxon signed-rank test to explore if the EPDS mean ranks changed after the consultations compared to the beforeintervention state [68]. 


\section{Results}

\subsection{Sample characteristics}

The age of the responding women from the screening program were 18-47 years, the mean age was $30.63(\mathrm{SD}=5.040)$. From the responding women $3448(83.1 \%)$ were in a relationship, engaged or married; 2348 women (56.6\%) primiparas and 502 women $(12.2 \%)$ did not plan her pregnancy (Table 1$)$.

Table 1: Demographic data of all women, who took part in the screening program from its beginning.

\begin{tabular}{|c|c|c|c|c|c|}
\hline & & $\mathrm{N}$ & Range & Mean & SD \\
\hline & Age & 4347 & $18-47$ & 30.63 & 5.040 \\
\hline & & & & & \\
\hline Marital & $\begin{array}{l}\text { In a relationship } \\
\text { / engaged } \\
\text { / married }\end{array}$ & & & & \\
\hline status & $\begin{array}{l}\text { Single } \\
\text { / divorced } \\
\text { / widowed }\end{array}$ & & & & \\
\hline Number of & None & & & & \\
\hline children & At least one & & & & \\
\hline & Planned & & & & \\
\hline 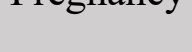 & Unplanned & & & & \\
\hline
\end{tabular}

The demographic data of our actual sample with 2042 women, whose data were used in the statistical analyses, were the following: the responding women's age were 18-44 years, the mean age of the sample was $30.43(\mathrm{SD}=4.840)$. From the responding women 1527 $(82.4 \%)$ were in a relationship, engaged or married; 1048 women $(56.3 \%)$ were primiparas and 218 women (11.8\%) did not plan their pregnancy (Table 2). 
Table 2: Demographic data of the sample of women whose obstetric data were collected.

\begin{tabular}{|c|c|c|c|c|c|}
\hline & & $\mathrm{N}$ & Range & Mean & SD \\
\hline & Age & 1992 & $18-44$ & 30.43 & 4.840 \\
\hline & & & & & \\
\hline Marital & $\begin{array}{l}\text { In a relationship } \\
\text { / engaged } \\
\text { / married }\end{array}$ & & & & \\
\hline status & $\begin{array}{l}\text { Single } \\
\text { / divorced } \\
\text { / widowed }\end{array}$ & & & & \\
\hline Number of & None & & & & \\
\hline children & At least one & & & & \\
\hline & Planned & & & & \\
\hline 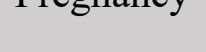 & Unplanned & & & & \\
\hline
\end{tabular}

We analyzed the demographic characteristics separately for the intervention and nonintervention groups, too. In the nonintervention group, the responding women's ages ranged from 18 to 44 years $($ mean $=30.46 \mathrm{SD}=4.797)$. In this group, 1428 women $(83 \%)$ were in a relationship, engaged or married; 963 women (55.8\%) did not have any children yet, and 184 women $(10.8 \%)$ had not planned their pregnancy. In the intervention group, the responding women's ages ranged from 18 to 43 years (mean $=30.11 \mathrm{SD}=5.386)$. In this group, 99 women (74.4\%) were in a relationship, engaged or married; 85 women (63.4\%) did not have any children yet, and 34 women $(25.4 \%)$ had not planned their pregnancy. To sum up, women in the intervention group were less likely to be in a relationship, more likely to be having their first child, and almost two-and-a-half times more likely to be having an unplanned pregnancy (Table 3 ). 
Table 3: Demographic data of women in the intervention and non-intervention groups

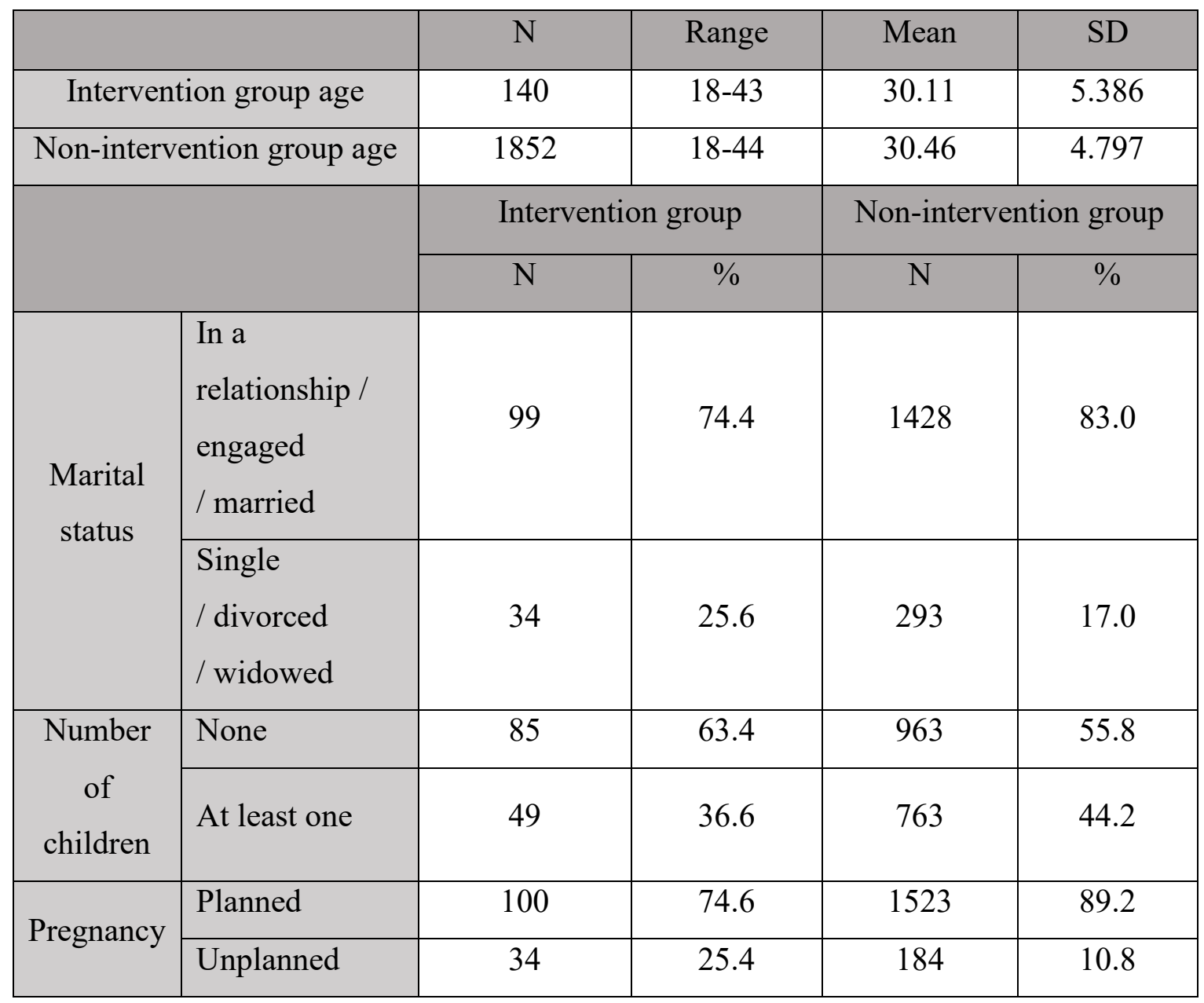

The EPDS questionnaires were obtained around week 10.59 in the first trimester, week 22.44 and 34.43 in the second and third trimester and week 4.81 after childbirth.

\subsection{Assessment of depressive scores and pathologic rate}

According to the Friedman's test on the data of the 2042 women, the EPDS mean ranks changed over time as pregnancy went on and after the child was born: the highest mean rank was found in the first trimester (mean rank $=2.93$ ), then in the second trimester (mean rank $=2.43)$, followed by the postpartum phase (mean rank $=2.38)$, then the third trimester (mean rank $=2.26$ ). There was a statistically significant difference in the EPDS scores between the measuring occasions: $\chi^{2}(3)=392.191, p<0.001$. Dunn-Bonferroni post hoc tests were carried out and the results showed that there were significant differences between 
all mean scores (all $p<0.038$ ), except for the second trimester and postpartum period $(p=0.948)($ Figure 1).

Figure 1: The EPDS mean ranks of the four measuring occasions $(\mathrm{N}=2042)$.

\section{EPDS mean ranks}

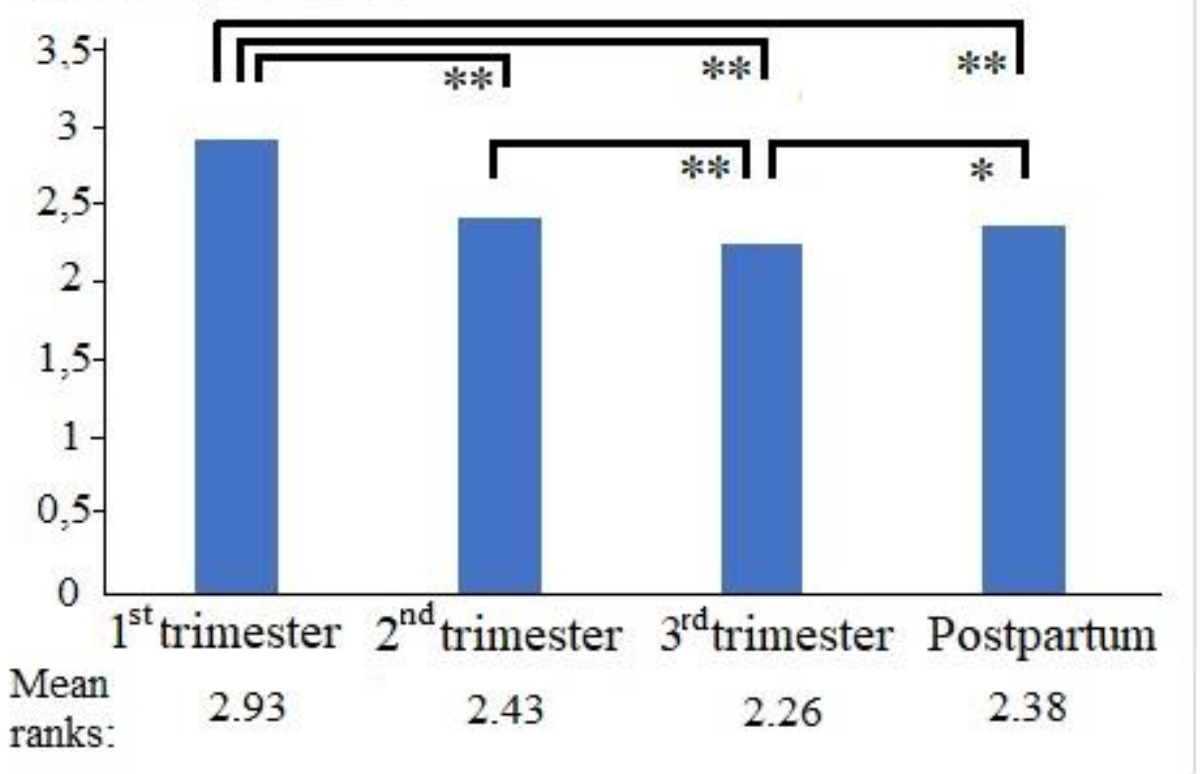

\footnotetext{
* means $p=0.038$

$* *$ means $p<0.001$
}

The Frequencies analysis on depressive and non-depressive groups revealed that $16.8 \%$ of the respondents were depressed in the first trimester (unsupplemented sample size: 1859), $12.2 \%$ and $10.5 \%$ in the second and third trimester (unsupplemented sample sizes: 1637 and 1395) and 7.7\% in the postpartum phase (unsupplemented sample size: 1138) (Figure 2). When the whole antepartum phase was in focus, $24 \%$ (unsupplemented sample size: 2028) of women had pathologic number of depressive scores at least once during their pregnancies. 
Figure 2: Pathologic rate of the sample.

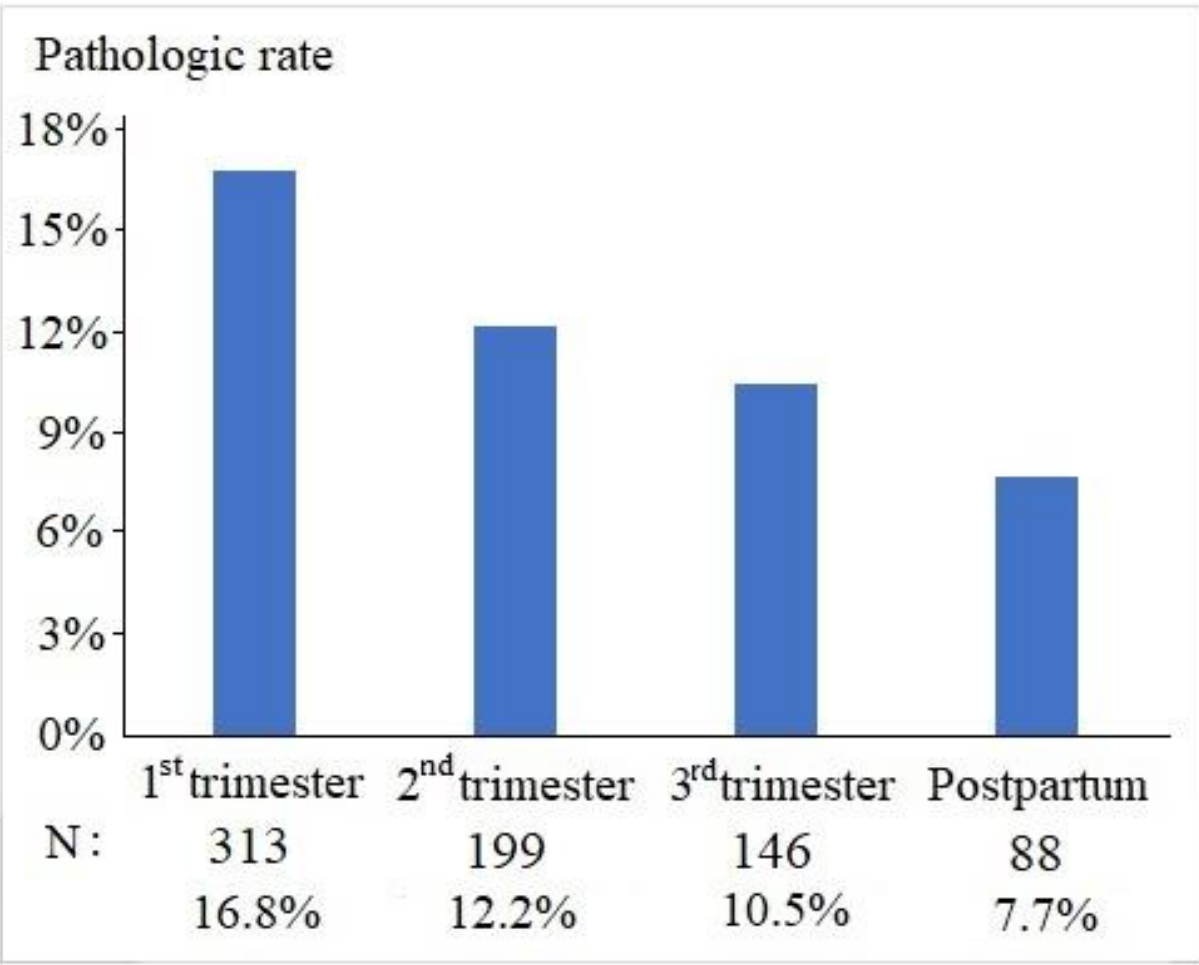

\subsection{Relation between the antepartum and the postpartum EPDS scores}

According to the Pearson Correlation the EPDS scores of all trimesters and the postpartum phase correlated significantly, positively with each other, with weak and moderate correlation (all $p<0.001,0.261<\mathrm{r}<0.464$ ) (Table 4).

Table 4: The EPDS scores significantly correlated with each other in all measuring occasions $(\mathrm{N}=2042)$.

\begin{tabular}{|c|c|c|c|c|c|}
\hline & & $1^{\text {st }}$ trimester & $2^{\text {nd }}$ trimester & $3^{\text {rd }}$ trimester & Postpartum \\
\hline \multirow{2}{*}{$1^{\text {st }}$ trimester } & $\mathrm{r}$ & 1 & 0.434 & 0.305 & 0.262 \\
\hline & $p$ & & $<0.001^{* *}$ & $<0.001 * *$ & $<0.001 * *$ \\
\hline \multirow{2}{*}{$2^{\text {nd }}$ trimester } & $\mathrm{r}$ & 0.434 & 1 & 0.463 & 0.306 \\
\hline & $p$ & $<0.001 * *$ & & $<0.001 * *$ & $<0.001 * *$ \\
\hline \multirow{2}{*}{$3^{\text {rd }}$ trimester } & $\mathrm{r}$ & 0.305 & 0.463 & 1 & 0.324 \\
\hline & $p$ & $<0.001 * *$ & $<0.001 * *$ & & $<0.001 * *$ \\
\hline \multirow{2}{*}{ Postpartum } & $r$ & 0.262 & 0.306 & 0.324 & 1 \\
\hline & $p$ & $<0.001 * *$ & $<0.001^{* *}$ & $<0.001 * *$ & \\
\hline
\end{tabular}

$* *$ means $p<0.001$ 
We used the same method separately on the intervention and non-intervention groups and interesting results were found: in the non-intervention group the tendency was the same, namely all EPDS scores correlated with each other significantly, positively, with weak and moderate correlation (all $p<0.001,0.246<\mathrm{r}<0.482$ ); but in the intervention group only the second and third trimester's EPDS scores correlated with each other significantly, $\mathrm{r}(150)=0.240, p=0.003$, all other $p>0.105$ (Table 5).

Table 5: The EPDS scores significantly correlated with each other in all measuring occasions in the non-intervention group, but not in the intervention group.

\begin{tabular}{|c|c|c|c|c|c|c|}
\hline & & & $\begin{array}{l}1^{\text {st }} \\
\text { trimester }\end{array}$ & $\begin{array}{l}2^{\text {nd }} \\
\text { trimester }\end{array}$ & $\begin{array}{l}3^{\text {rd }} \\
\text { trimester }\end{array}$ & Postpartum \\
\hline \multirow{8}{*}{$\begin{array}{c}\text { Non- } \\
\text { intervention } \\
\text { group } \\
(\mathrm{N}=1892)\end{array}$} & \multirow{2}{*}{$\begin{array}{c}1^{\text {st }} \\
\text { trimester }\end{array}$} & $\mathrm{r}$ & \multirow[t]{2}{*}{1} & 0.444 & 0.331 & 0.247 \\
\hline & & $p$ & & $<0.001 * *$ & $<0.001 * *$ & $<0.001 * *$ \\
\hline & \multirow{2}{*}{$\begin{array}{c}2^{\text {nd }} \\
\text { trimester }\end{array}$} & $\mathrm{r}$ & 0.444 & \multirow[t]{2}{*}{1} & 0.481 & 0.314 \\
\hline & & $p$ & $<0.001 * *$ & & $<0.001 * *$ & $<0.001 * *$ \\
\hline & \multirow{2}{*}{$\begin{array}{c}3^{\text {rd }} \\
\text { trimester }\end{array}$} & $\mathrm{r}$ & 0.331 & 0.481 & \multirow[t]{2}{*}{1} & 0.346 \\
\hline & & $p$ & $<0.001 * *$ & $<0.001 * *$ & & $<0.001 * *$ \\
\hline & \multirow{2}{*}{ Postpartum } & $\mathrm{r}$ & 0.247 & 0.314 & 0.346 & \multirow[t]{2}{*}{1} \\
\hline & & $p$ & $<0.001 * *$ & $<0.001 * *$ & $<0.001 * *$ & \\
\hline \multirow{8}{*}{$\begin{array}{c}\text { Intervention } \\
\text { group } \\
(\mathrm{N}=150)\end{array}$} & \multirow{2}{*}{$\begin{array}{c}1^{\text {st }} \\
\text { trimester }\end{array}$} & $\mathrm{r}$ & \multirow[t]{2}{*}{1} & 0.100 & -0.032 & 0.114 \\
\hline & & $\bar{p}$ & & 0.221 & 0.702 & 0.166 \\
\hline & \multirow{2}{*}{$\begin{array}{c}2^{\text {nd }} \\
\text { trimester }\end{array}$} & $\mathrm{r}$ & 0.100 & \multirow[t]{2}{*}{1} & 0.240 & 0.114 \\
\hline & & $p$ & 0.221 & & $0.003 *$ & 0.166 \\
\hline & \multirow{2}{*}{$\begin{array}{c}3^{\text {rd }} \\
\text { trimester }\end{array}$} & $\mathrm{r}$ & -0.032 & 0.240 & \multirow[t]{2}{*}{1} & 0.133 \\
\hline & & $\bar{p}$ & 0.702 & $0.003 *$ & & 0.106 \\
\hline & \multirow{2}{*}{ Postpartum } & $\mathrm{r}$ & 0.114 & 0.114 & 0.133 & \multirow[t]{2}{*}{1} \\
\hline & & $p$ & 0.166 & 0.166 & 0.106 & \\
\hline
\end{tabular}




\subsection{Features of the intervention, participation rate, EPDS scores}

According to the data of the intervention group (with 150 women) the number of sessions varied from one to twenty, the mean was $3.4(\mathrm{SD}=3.9)$. The problems that were the focus of the interventions also varied. These were the following: stress, low mood, panic symptoms, irritability, anxiety, exhaustion, relationship difficulties, conflicts with own mother or mother-in-law, feelings of being a bad mother, fear of delivery and the future, uncertainty about wanting the fetus, obsessive thoughts, previous abortion or stillbirth, posttraumatic stress symptoms from previous cesarean section, preterm birth and unplanned pregnancy. In some cases, women learned about their pregnancy in the second trimester, it could also cause a complication.

From the sample 1561 (76.44\%) women did not need intervention, but 37 of them came anyway, because they felt they needed to. According to the EPDS scores, $481(23.56 \%)$ women were offered consultation, but only 113 (23.5\%) of them attended (Table 6).

Table 6: The rate of women who took part in the intervention, whether it was recommended to them or not.

\begin{tabular}{|c|c|c|c|}
\hline & $\begin{array}{l}\text { Attended to the } \\
\text { intervention } \\
(\mathrm{N}=150)\end{array}$ & $\begin{array}{l}\text { Did not attend to } \\
\text { the intervention } \\
\qquad(\mathrm{N}=1892)\end{array}$ & Total \\
\hline $\begin{array}{l}\text { EPDS score over } \\
\text { the cut-off value }\end{array}$ & $\begin{array}{l}\mathrm{N}=113 \\
(\mathbf{2 3 . 5 \% )}\end{array}$ & $\begin{array}{l}\mathrm{N}=368 \\
(\mathbf{7 6 . 5 \% )}\end{array}$ & $\begin{array}{l}\mathrm{N}=481 \\
(\mathbf{1 0 0 \%})\end{array}$ \\
\hline $\begin{array}{l}\text { EPDS score under } \\
\text { the cut-off value }\end{array}$ & $\begin{array}{l}\mathrm{N}=37 \\
(2.4 \%)\end{array}$ & $\begin{array}{l}N=1524 \\
(97.6 \%)\end{array}$ & $\begin{array}{c}\mathrm{N}=1561 \\
(100 \%)\end{array}$ \\
\hline
\end{tabular}

According to the Wilcoxon signed-rank test the EPDS mean ranks significantly decreased after the consultations compared to the before-intervention state, from 38.75 to $25.57, Z=$ $6.518, p<0.001$ (Table 7).

Table 7: The EPDS mean ranks before and after the intervention $(\mathrm{N}=78)$

\begin{tabular}{|c|c|c|c|}
\hline & Before intervention & After intervention & $p$ \\
\hline Mean rank & 38.75 & 25.57 & $<0.001$ \\
\hline
\end{tabular}


The Kruskal-Wallis test revealed that there were significant differences in the EPDS mean ranks in all four measuring occasions between women who started the intervention in different trimesters or did not attend it at all (all $p<0.001$ ). In all cases the women had the lowest mean ranks who did not come to the intervention. The pairwise comparisons are presented in Figure 3.

Figure 3: Pairwise comparisons (with Bonferroni correction) of the EPDS mean ranks of women who started to attend the interventions in different trimesters or did not attend at all.

** means $p<0.001$

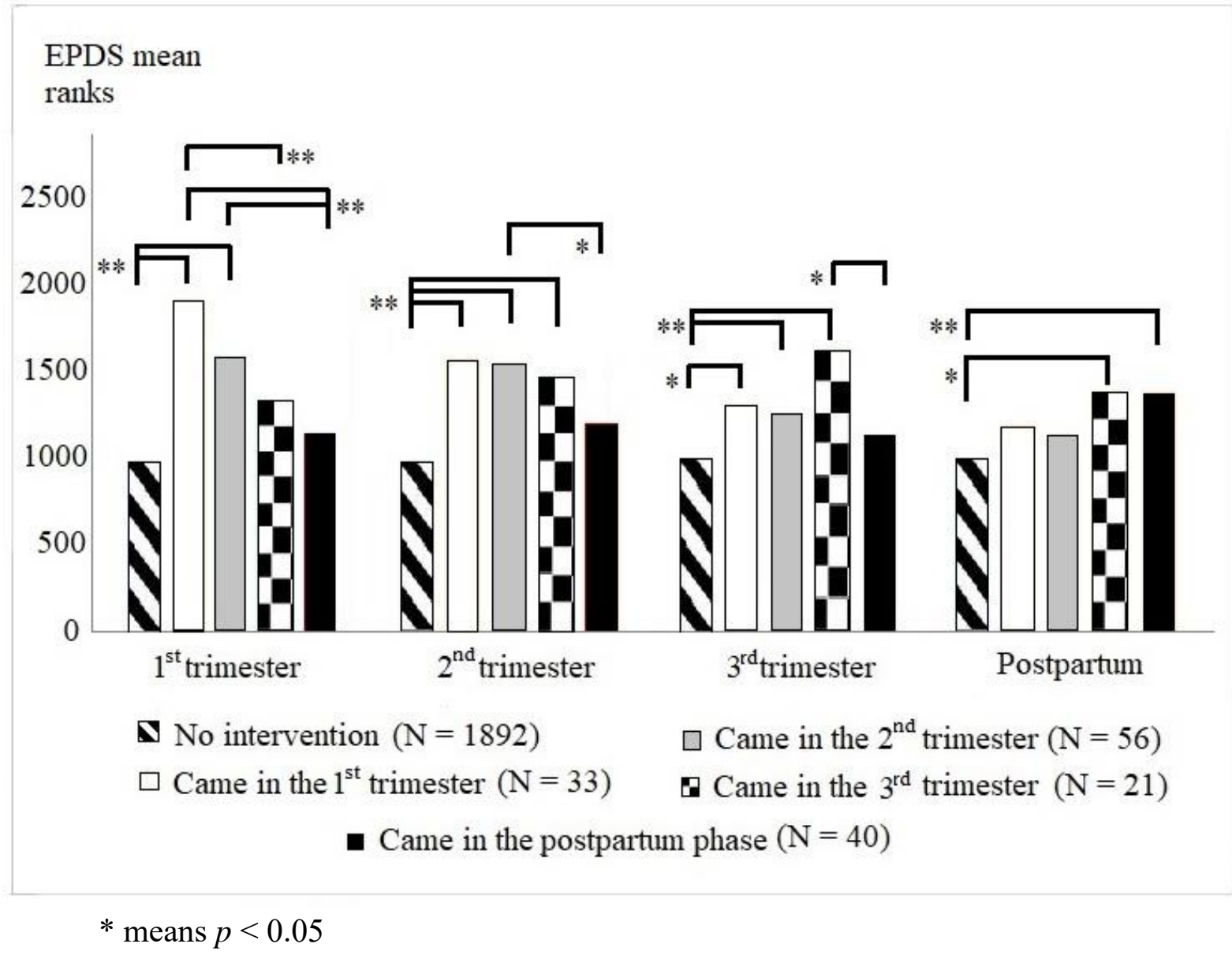

\subsection{EPDS scores and pre- and peripartum complications}

The Mann-Whitney U tests with Bonferroni corrections showed that some of the pre- and peripartum complications are connected to the EPDS mean ranks. 
Statistically significant relationship was found between EPDS mean ranks of the postpartum phase and protracted cervical dilation: the mean rank of women, who had protracted dilation, was higher after childbirth $(U=67835.5, p<0.001)$ (Table 8).

Table 8: EPDS mean ranks in the postpartum phase were connected to protracted cervical dilation.

\begin{tabular}{|c|c|c|c|c|}
\hline & \multicolumn{5}{c|}{ EPDS mean ranks } \\
& \multirow{2}{*}{$1^{\text {st }}$ trimester } & $2^{\text {nd }}$ trimester & $3^{\text {rd }}$ trimester & $\begin{array}{c}\text { Postpartum } \\
\text { phase }\end{array}$ \\
\hline Protracted cervical dilation $(\mathrm{N}=129)$ & 833.07 & 834.74 & 825.2 & $\mathbf{8 0 6 . 5 4}$ \\
No complication $(\mathrm{N}=1523)$ & 825.94 & 825.8 & 841.79 & $\mathbf{1 0 6 2 . 1 4}$ \\
$p$ & 0.870 & 0.835 & 0.693 & $\mathbf{0 . 0 0 0} *$ \\
\hline
\end{tabular}

The relationship is significant if $\mathrm{p} \leq 0.007$ (Bonferroni correction).

* means significant

Tendency relationship was found with protracted descent grouping in the second trimester $(U=30435, p=0.043)$ and statistically significant relationships in the third trimester and postpartum period $(U=24141.5, p<0.001$ and $U=23994.5, p<0.001)$. In all three cases the women's mean ranks were higher who had this complication (Table 9).

Table 9: EPDS mean ranks were connected to protracted descent.

\begin{tabular}{|c|c|c|c|c|}
\hline & \multicolumn{4}{|c|}{ EPDS mean ranks } \\
\hline & $1^{\text {st }}$ trimester & $2^{\text {nd }}$ trimester & $3^{\text {rd }}$ trimester & $\begin{array}{c}\text { Postpartum } \\
\text { phase }\end{array}$ \\
\hline Protracted descent $(\mathrm{N}=48)$ & 856.44 & 913.44 & 1044.55 & 1047.61 \\
\hline No complication $(\mathrm{N}=1523)$ & 783.78 & 781.98 & $\mathbf{7 7 7 . 8 5}$ & 777.75 \\
\hline$p$ & 0.271 & $0.043^{t}$ & $0.000 *$ & $0.000 *$ \\
\hline
\end{tabular}

The relationship is significant if $\mathrm{p} \leq 0.007$ (Bonferroni correction).

* means significant

${ }^{\mathrm{t}}$ means tendency relationship. 
With the preeclampsia grouping variable, we found statistically significant connection in the postpartum phase: the women, who had preeclampsia in their pregnancies, had higher mean rank after their delivery, compared to women who did not have preeclampsia, $U=28341.5, p<0.001$ (Table 10).

Table 10: EPDS mean ranks were connected to preeclampsia.

\begin{tabular}{|c|c|c|c|c|}
\hline & \multicolumn{4}{|c|}{ EPDS mean ranks } \\
\hline & $1^{\text {st }}$ trimester & $2^{\text {nd }}$ trimester & $3^{\text {rd }}$ trimester & $\begin{array}{c}\text { Postpartum } \\
\text { phase }\end{array}$ \\
\hline Preeclampsia $(\mathrm{N}=52)$ & 817.08 & 837.52 & 698.97 & 1004.47 \\
\hline No complication $(\mathrm{N}=1523)$ & 787.01 & 786.31 & 791.04 & 780.61 \\
\hline$p$ & 0.636 & 0.414 & 0.135 & $0.000 *$ \\
\hline
\end{tabular}

The relationship is significant if $\mathrm{p} \leq 0.007$ (Bonferroni correction).

* means significant

We have found tendency relationship between IUGR and EPDS mean ranks in the second and third trimester: the mean rank of women, whose fetus growth was restricted, tended to be higher compared to women who did not have an IUGR fetus, $U=15249.5, p=0.018$ and $U=16047.5, p=0.042$ (Table 11).

Table 11: EPDS mean ranks were connected to IUGR.

\begin{tabular}{|c|c|c|c|c|}
\hline \multicolumn{5}{|c|}{ EPDS mean ranks } \\
phese \\
\hline 1UGR $(\mathrm{N}=27)$ & 797.91 & $\mathbf{9 7 2 . 2 0}$ & $\mathbf{9 4 2 . 6 5}$ & 846.83 \\
No complication $(\mathrm{N}=1523)$ & 775.10 & $\mathbf{7 7 2 . 0 1}$ & $\mathbf{7 7 2 . 5 4}$ & 774.24 \\
$p$ & 0.791 & $\mathbf{0 . 0 1 8}^{\text {st }}$ & $\mathbf{0 . 0 4 2}^{\mathbf{t}}$ & 0.366 \\
\hline
\end{tabular}

The relationship is significant if $\mathrm{p} \leq 0.007$ (Bonferroni correction).

${ }^{\mathrm{t}}$ means tendency relationship. 
Statistically significant relationship was found between low birthweight and EPDS mean ranks in the second trimester, $U=56185.5, p<0.001$ and further tendency relationships in the third trimester and postpartum period, $U=62948, p=0.040$ and $U=63842, p=0.057$ (Table 12). In all cases the women had higher mean ranks, whose newborn had low birthweight.

Table 12: EPDS mean ranks were connected to low birthweight.

\begin{tabular}{|c|c|c|c|c|}
\hline & \multicolumn{5}{|c|}{ EPDS mean ranks } \\
& \multirow{2}{*}{$1^{\text {st }}$ trimester } & $2^{\text {nd }}$ trimester & $3^{\text {rd }}$ trimester & $\begin{array}{c}\text { Postpartum } \\
\text { phase }\end{array}$ \\
\hline Low birthweight $(\mathrm{N}=94)$ & 861.01 & $\mathbf{9 7 2 . 7 8}$ & $\mathbf{9 0 0 . 8 4}$ & $\mathbf{8 9 1 . 3 3}$ \\
No complication $(\mathrm{N}=1523)$ & 805.79 & $\mathbf{7 9 8 . 8 9}$ & $\mathbf{8 0 3 . 3 3}$ & $\mathbf{8 0 3 . 9 2}$ \\
$p$ & 0.262 & $\mathbf{0 . 0 0 0} *$ & $\mathbf{0 . 0 4 0}^{\mathbf{t}}$ & $\mathbf{0 . 0 5 7}^{\mathbf{t}}$ \\
\hline
\end{tabular}

The relationship is significant if $\mathrm{p} \leq 0.007$ (Bonferroni correction).

* means significant

${ }^{\mathrm{t}}$ means tendency relationship.

Between EPDS mean ranks and premature birth or GDM no connection was found, all $p>0.117$ (Table 13 and Table 14).

Table 13: EPDS mean ranks were not connected to premature birth.

\begin{tabular}{|c|c|c|c|c|}
\hline & \multicolumn{4}{|c|}{ EPDS mean ranks } \\
\hline & $1^{\text {st }}$ trimester & $2^{\text {nd }}$ trimester & $3^{\text {rd }}$ trimester & $\begin{array}{c}\text { Postpartum } \\
\text { phase }\end{array}$ \\
\hline Premature birth $(\mathrm{N}=143)$ & 835.40 & 812.82 & 891.23 & 843.04 \\
\hline No complication $(\mathrm{N}=1523)$ & 833.32 & 835.44 & 828.08 & 832.60 \\
\hline$p$ & 0.960 & 0.583 & 0.118 & 0.788 \\
\hline
\end{tabular}

The relationship is significant if $\mathrm{p} \leq 0.007$ (Bonferroni correction). 
Table 14: EPDS mean ranks were not connected to GDM.

\begin{tabular}{|c|c|c|c|c|}
\hline \multicolumn{5}{|c|}{ EPDS mean ranks } \\
\multicolumn{2}{|c}{} \\
\multicolumn{2}{|c}{$1^{\text {st }}$ trimester } & $2^{\text {nd }}$ trimester & $3^{\text {rd }}$ trimester & $\begin{array}{c}\text { Postpartum } \\
\text { phase }\end{array}$ \\
\hline GDM $(\mathrm{N}=181)$ & 829.24 & 861.46 & 823.73 & 804.85 \\
$p$ & 855.24 & 851.44 & 855.92 & 858.16 \\
\hline No complication $(\mathrm{N}=1523)$ & 0.501 & 0.791 & 0.386 & 0.136 \\
\hline
\end{tabular}

The relationship is significant if $\mathrm{p} \leq 0.007$ (Bonferroni correction).

\subsection{Intervention and pre- and peripartum complications}

The Pearson's Chi-square tests revealed no significant differences between the intervention and non-intervention groups in the following pre- and peripartum complications: preeclampsia, GDM, IUGR, premature birth, low birthweight, protracted cervical dilation and protracted descent (all $p>0.150$ ).

\subsection{EPDS scores and mode of delivery}

According to the Mann-Whitney $U$ test there was a connection between the EPDS mean ranks and mode of delivery. It was found that the women, who had a cesarean section had significantly higher mean ranks in the postpartum period compared to women who had vaginal birth, $U=467991, p=0.007$. No significant connection was found during the other measuring occasions, all $p>0.184$ (Table 15). 
Table 15: The EPDS mean ranks of women who had cesarean section or vaginal delivery in all measuring occasions.

\begin{tabular}{|c|c|c|c|}
\hline & $\begin{array}{l}\text { EPDS mean ranks } \\
\text { in the vaginal birth } \\
\text { group }(\mathrm{N}=1214)\end{array}$ & $\begin{array}{l}\text { EPDS mean ranks } \\
\text { in the cesarean } \\
\text { section group } \\
(\mathrm{N}=826)\end{array}$ & $p$ \\
\hline $1^{\text {st }}$ trimester & 1014.84 & 1028.81 & 0.596 \\
\hline $2^{\text {nd }}$ trimester & 1006.52 & 1041.04 & 0.185 \\
\hline $3^{\text {rd }}$ trimester & 1012.69 & 1031.98 & 0.452 \\
\hline Postpartum & 993.00 & 1060.92 & $0.007^{*}$ \\
\hline
\end{tabular}

* means $p<0.05$

\subsection{Intervention and mode of delivery}

The Pearson's Chi-square tests showed a relationship between intervention and mode of delivery. The result showed that the women who began the intervention during their pregnancies were significantly less likely to have a cesarean section compared to women who did not participate in the intervention $(30.9 \%$ vs $40.69 \%), \chi^{2}(1)=4.137, p=0.042$ (Table 16).

Table 16: The association between starting the intervention during pregnancy and mode of delivery.

\begin{tabular}{|c|c|c|c|}
\hline & $\begin{array}{c}\text { Non-intervention } \\
\text { group during } \\
\text { pregnancy }\end{array}$ & $\begin{array}{c}\text { Intervention group } \\
\text { during pregnancy }\end{array}$ & $p$ \\
\hline Vaginal birth & 1121 & 76 & \\
$(\mathrm{~N}=1197)$ & $(59.31 \%)$ & $(69.09 \%)$ & \multirow{2}{*}{$0.042^{*}$} \\
\hline $\begin{array}{c}\text { Cesarean section } \\
(\mathrm{N}=803)\end{array}$ & $\begin{array}{c}769 \\
\mathbf{( 4 0 . 6 9 \% )}\end{array}$ & $\mathbf{( 3 0 . 9 1 \% )}$ & \\
\hline Total (N) & 1890 & 110 & \\
\hline
\end{tabular}

* means $p<0.05$ 
There was also a significant relationship in the postpartum phase: the women who had cesarean section were significantly more likely to ask for psychological consultation than the women who had vaginal birth $(2.9 \%$ vs $1.5 \%), \chi^{2}(1)=4.576, p=0.032$ (Table 17).

Table 17: The association between mode of delivery and starting the intervention in the postpartum phase.

\begin{tabular}{|c|c|c|c|}
\hline \multirow{7}{*}{ Vaginal birth } & $\begin{array}{c}\text { Non-intervention } \\
\text { group in the } \\
\text { postpartum phase } \\
(\mathrm{N}=1890)\end{array}$ & $\begin{array}{c}\text { Intervention group } \\
\text { in the postpartum } \\
\text { phase } \\
(\mathrm{N}=40)\end{array}$ & Total (N) \\
\hline Cesarean section & $\begin{array}{c}1121 \\
(98.5 \%)\end{array}$ & $\begin{array}{c}17 \\
(1.5 \%)\end{array}$ & $(100 \%)$ \\
\hline$p$ & $(97.1 \%)$ & 23 & 792 \\
& & $0.032 *$ & $(100 \%)$ \\
\hline
\end{tabular}

* means $p<0.05$

\subsection{Demographic variables and EPDS scores}

The Mann-Whitney U tests revealed significant relationships between the EPDS mean ranks and demographical variables (marital status, number of children and planning of pregnancy).

Our results have shown that the women who did not plan their pregnancies had significantly higher mean ranks in all trimesters and tended to have higher mean rank in the postpartum phase compared to the women who planned their pregnancies: in the first trimester $U=134727.5, p<0.001$, in the second trimester $U=147653, p<0.001$, in the third trimester $U=144896.5, p<0.001$ and in the postpartum phase $U=161046.5, p=0.022$ (Table 18). 
Table 18: EPDS mean ranks of women who had planned $(\mathrm{N}=1623)$ or unplanned $(\mathrm{N}=218)$ pregnancies in all measuring occasions.

\begin{tabular}{|c|c|c|c|}
\hline & & EPDS mean ranks & $p$ \\
\hline $1^{\text {st }}$ trimester & $\begin{array}{c}\text { Unplanned } \\
\text { pregnancy } \\
\text { Planned pregnancy }\end{array}$ & $\begin{array}{l}1114.48 \\
895.01\end{array}$ & $<0.001 * *$ \\
\hline $2^{\text {nd }}$ trimester & $\begin{array}{c}\text { Unplanned } \\
\text { pregnancy } \\
\text { Planned pregnancy }\end{array}$ & $\begin{array}{l}1055.19 \\
902.98\end{array}$ & $<0.001 * *$ \\
\hline $3^{\text {rd }}$ trimester & $\begin{array}{c}\text { Unplanned } \\
\text { pregnancy } \\
\text { Planned pregnancy }\end{array}$ & $\begin{array}{l}1067.84 \\
901.28\end{array}$ & $<0.001 * *$ \\
\hline Postpartum & $\begin{array}{c}\text { Unplanned } \\
\text { pregnancy } \\
\text { Planned pregnancy }\end{array}$ & $\begin{array}{l}993.75 \\
911.23\end{array}$ & $0.022 *$ \\
\hline
\end{tabular}

When marital status was in focus we found that single, divorced or widowed women had higher mean ranks in all measuring occasions compared to women who were in a relationship or married, but the differences were significant only in the first and second trimester, $U=223396.5, p=0.003$ and $U=223011, p=0.002$ (Table 19). 
Table 19: EPDS mean ranks of women who were single/divorced/widowed $(\mathrm{N}=327)$ or in a relationship/engaged/married $(\mathrm{N}=1527)$ in all measuring occasions.

\begin{tabular}{|c|c|c|c|}
\hline & & EPDS mean ranks & $p$ \\
\hline \multirow{2}{*}{$1^{\text {st }}$ trimester } & $\mathrm{S} / \mathrm{D} / \mathrm{W}$ & 1007.83 & \multirow{2}{*}{$0.003 *$} \\
\hline & $\mathrm{Ir} / \mathrm{E} / \mathrm{M}$ & 910.30 & \\
\hline \multirow{2}{*}{$2^{\text {nd }}$ trimester } & $\mathrm{S} / \mathrm{D} / \mathrm{W}$ & 1009.01 & \multirow{2}{*}{$0.002 *$} \\
\hline & $\mathrm{Ir} / \mathrm{E} / \mathrm{M}$ & 910.05 & \\
\hline \multirow{2}{*}{$3^{\text {rd }}$ trimester } & $\mathrm{S} / \mathrm{D} / \mathrm{W}$ & 933.84 & \multirow{2}{*}{0.807} \\
\hline & $\mathrm{Ir} / \mathrm{E} / \mathrm{M}$ & 926.14 & \\
\hline \multirow{2}{*}{ Postpartum } & $\mathrm{S} / \mathrm{D} / \mathrm{W}$ & 934.63 & \multirow{2}{*}{0.778} \\
\hline & $\mathrm{Ir} / \mathrm{E} / \mathrm{M}$ & 925.97 & \\
\hline
\end{tabular}

$\mathrm{S} / \mathrm{D} / \mathrm{W}$ means single/divorced/widowed. Ir/E/M means in a relationship/engaged /married.

* means $p<0.05$

With the variable number of children, the results were not this straight forward: during pregnancy the women had higher mean ranks who had already had at least one child, but in the postpartum period women with no children had higher mean rank. The difference was significant only in the postpartum phase, $U=392145.5, p=0.002$ (Table 20).

Table 20: EPDS mean ranks of women who had at least one child $(\mathrm{N}=812)$ or no child at all $(\mathrm{N}=1048)$ in all measuring occasions.

\begin{tabular}{|cc|c|c|}
\hline & \multicolumn{2}{|c|}{ EPDS mean ranks } & $p$ \\
\hline \multirow{2}{*}{$1^{\text {st }}$ trimester } & No child & 914.22 & 0.134 \\
& At least one child & 951.52 & 0.176 \\
\hline \multirow{2}{*}{$2^{\text {nd }}$ trimester } & No child & 915.95 & 0.124 \\
& At least one child & 949.28 & $0.002^{*}$ \\
\hline \multirow{2}{*}{$3^{\text {rd }}$ trimester } & No child & 914.20 & \multirow{2}{*}{ At least one child } \\
\hline \multirow{2}{*}{ Postpartum } & No child & 951.54 & \\
& At least one child & 862.32 & \\
\hline
\end{tabular}

$*$ means $p<0.05$ 
When age was in focus the Kruskal-Wallis test with Bonferroni correction showed that the youngest group (women under 21) had the highest mean ranks and groups 26-30 and 3135 years old had the lowest mean ranks in most of the cases. The difference between groups was significant in all trimesters $(p<0.005)$, but not in the postpartum phase $(p=0.926)$ (Table 21). The differences of the EPDS mean ranks between the age groups in all trimesters are presented in Figure 4.

Table 21: EPDS mean ranks of women in different age groups in all measuring occasions.

\begin{tabular}{|c|c|c|c|c|}
\hline & Age & $\mathrm{N}$ & $\begin{array}{c}\text { EPDS mea } \\
\text { ranks }\end{array}$ & $p$ \\
\hline \multirow{5}{*}{$1^{\text {st }}$ trimester } & $\leq 20$ & 56 & 1211.02 & \multirow{5}{*}{$0.004 *$} \\
\hline & $21-25$ & 525 & 1070.89 & \\
\hline & $26-30$ & 668 & 973.62 & \\
\hline & $31-35$ & 721 & 967.59 & \\
\hline & $36 \leq$ & 295 & 1014.70 & \\
\hline \multirow{5}{*}{$2^{\text {nd }}$ trimester } & $\leq 20$ & 56 & 1250.29 & \multirow{5}{*}{$0.001^{*}$} \\
\hline & $21-25$ & 525 & 1070.06 & \\
\hline & $26-30$ & 668 & 994.39 & \\
\hline & $31-35$ & 721 & 954.91 & \\
\hline & $36 \leq$ & 295 & 991.91 & \\
\hline \multirow{5}{*}{$3^{\text {rd }}$ trimester } & $\leq 20$ & 56 & 1261.58 & \multirow{5}{*}{$0.001^{*}$} \\
\hline & $21-25$ & 525 & 1015.33 & \\
\hline & $26-30$ & 668 & 972.10 & \\
\hline & $31-35$ & 721 & 970.15 & \\
\hline & $36 \leq$ & 295 & 1049.74 & \\
\hline \multirow{5}{*}{ Postpartum } & $\leq 20$ & 56 & 1000.26 & \multirow{5}{*}{0.926} \\
\hline & $21-25$ & 525 & 1015.27 & \\
\hline & $26-30$ & 668 & 996.62 & \\
\hline & $31-35$ & 721 & 999.27 & \\
\hline & $36 \leq$ & 295 & 972.69 & \\
\hline
\end{tabular}

* means $p<0.05$ 
Figure 4: Pairwise comparisons (with Bonferroni correction) of the EPDS mean ranks between the age groups in all trimesters.

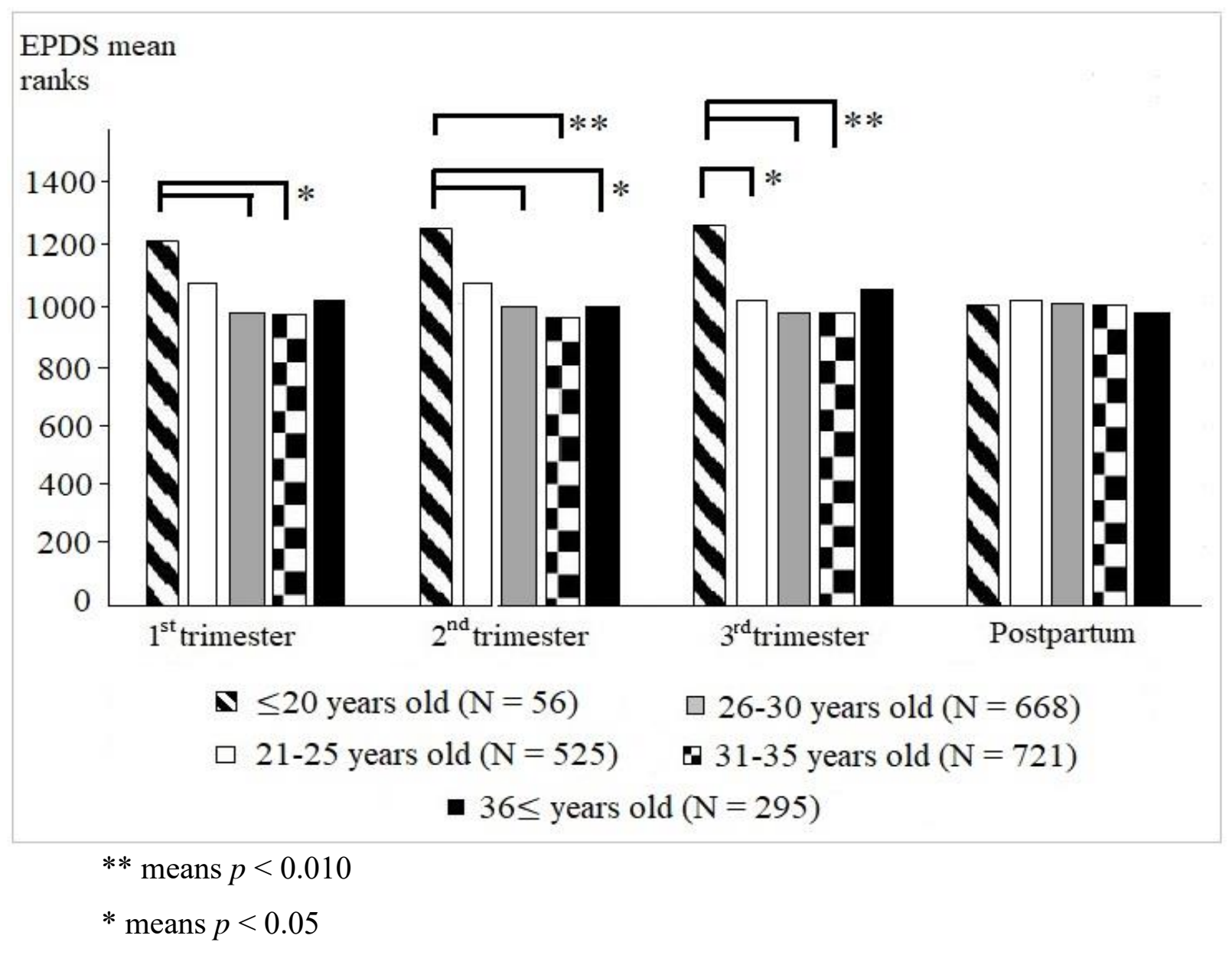

\subsection{Interventions and demographic data}

The Pearson Chi-square tests revealed significant relationships between intervention and some of the following demographic variables: marital status, parity, planned pregnancy. According to the results, the women who were single or divorced or widowed were significantly more likely to ask for intervention (10.4\%) compared to those, who were in a relationship or married $(6.5 \%), \chi^{2}(1)=6.197, p=0.013$ (Table 22). 
Table 22: The association between marital status and intervention.

\begin{tabular}{|c|c|c|c|c|c|}
\hline & & $\begin{array}{c}\text { Non-intervention } \\
\text { group } \\
(\mathrm{N}=1721)\end{array}$ & $\begin{array}{c}\text { Intervention } \\
\text { group } \\
(\mathrm{N}=133)\end{array}$ & Total $(\mathrm{N})$ & $p$ \\
\hline \multirow{2}{*}{$\begin{array}{l}\text { Marital } \\
\text { status }\end{array}$} & $\begin{array}{c}\text { Single / divorced / } \\
\text { widowed. }\end{array}$ & $\begin{array}{c}293 \\
(89.6 \%)\end{array}$ & $\begin{array}{c}34 \\
(\mathbf{1 0 . 4 \%})\end{array}$ & $\begin{array}{c}327 \\
(100 \%)\end{array}$ & \multirow{2}{*}{$0.013 *$} \\
\hline & $\begin{array}{l}\text { In a relationship / } \\
\text { engaged / married. }\end{array}$ & $\begin{array}{c}1428 \\
(93.5 \%)\end{array}$ & $\begin{array}{c}99 \\
(6.5 \%)\end{array}$ & $\begin{array}{c}1527 \\
(100 \%)\end{array}$ & \\
\hline
\end{tabular}

* means $p<0.05$

When pregnancy was in focus: the women whose pregnancy had been unplanned were more likely to ask for psychological consultation (15.6\%) compared to those who had planned it $(6.2 \%), \chi^{2}(1)=25.349, p<0.001$ (Table 23).

Table 23: The association between planned or unplanned pregnancy and intervention.

\begin{tabular}{|c|c|c|c|c|}
\hline & $\begin{array}{c}\text { Non-intervention } \\
\text { group } \\
(\mathrm{N}=1707)\end{array}$ & $\begin{array}{c}\text { Intervention } \\
\text { group } \\
(\mathrm{N}=134)\end{array}$ & Total $(\mathrm{N})$ & $p$ \\
\hline Unplanned pregnancy & $\begin{array}{c}184 \\
(84.4 \%)\end{array}$ & $\begin{array}{c}34 \\
(\mathbf{1 5 . 6 \% )}\end{array}$ & $\begin{array}{c}218 \\
(100 \%)\end{array}$ & \multirow{2}{*}{$<0.001 * *$} \\
\hline Planned pregnancy & $\begin{array}{c}1523 \\
(93.8 \%)\end{array}$ & $\begin{array}{c}100 \\
(\mathbf{6 . 2 \%})\end{array}$ & $\begin{array}{c}1623 \\
(100 \%)\end{array}$ & \\
\hline
\end{tabular}

However, when parity was considered, only tendency difference was obtained between the women who came to the consultations and did not have any children yet (8.1\%) and those who had at least one child $(6 \%), \chi^{2}(1)=2.950, p=0.086$ (Table 24). 
Table 24: The association between number of children and intervention.

\begin{tabular}{|c|c|c|c|c|}
\hline & $\begin{array}{l}\text { Non-intervention } \\
\text { group }(\mathrm{N}=1726)\end{array}$ & $\begin{array}{l}\text { nterventior } \\
\text { group } \\
(\mathrm{N}=134)\end{array}$ & Total $(\mathrm{N})$ & $p$ \\
\hline No child & $\begin{array}{c}963 \\
(91.9 \%)\end{array}$ & $\begin{array}{c}85 \\
(\mathbf{8 . 1 \%})\end{array}$ & $\begin{array}{c}1048 \\
(100 \%)\end{array}$ & \multirow{2}{*}{$0.086^{\mathrm{t}}$} \\
\hline At least one child & $\begin{array}{c}763 \\
(94 \%)\end{array}$ & $\begin{array}{c}49 \\
(6 \%)\end{array}$ & $\begin{array}{c}812 \\
(100 \%)\end{array}$ & \\
\hline
\end{tabular}

\section{Discussion}

\subsection{Assessment of EPDS scores and pathologic rate}

According to our results, the first trimester seems to be the most sensitive in the aspect of depression: it represented the highest EPDS mean rank with 2.93 points and the highest pathological rate (16.8\%). In our opinion, it can be explained by the fact that having a child is great responsibility and sometimes this can be overwhelming, even if the pregnancy was planned. When the pregnancy was unplanned women had to decide during a quite short period of time whether they wanted to keep the fetus or not, which could be distressing. Besides women could be afraid of miscarriage, which can affect every fifth pregnancy [71]. Other facts could also disturb this period, like morning sickness, existential anxiety, stress during medical examinations and so on.

In the second trimester both the EPDS mean rank and the pathological rate decreased $(2.43$ points and $12.2 \%$ ). This might have been, because the decision on keeping the fetus was made and women could start to bond with their fetus, as they could feel its movements, their abdomen was not too big yet to make movement and sleeping harder than usual. Besides after the ultrasound examination on the $12^{\text {th }}$ week women could become more relaxed if they found out that everything was fine with the fetus.

In our sample the third trimester seemed to be the most relaxed time during this time (mean rank $=2.26$, pathological rate $=10.5 \%$ ). It can be the result of the fact that the main plans and tasks have been done: many women said during the interventions that weeks before their delivery they had already finished the clean-up, rearranging the house, they had had 
the baby-furniture and the equipment to be able to take care of the newborn. Besides, by this time they could focus more on the relationship with their fetus, because they could feel its kicking and other movements; these positive feelings might help women cope with their difficulties, like the still growing abdomen, which could make moving and sleeping more and more difficult. In addition, many women were not afraid yet of the childbearing around the $34^{\text {th }}$ week, when the EPDS questionnaires were taken. Also, lots of women had already attended to the psychological intervention, which could also be in the background of the lower EPDS mean rank and pathological rate.

After delivery the mean ranks grew a little (2.38 points), but the pathological rate decreased (7.7\%). In our opinion, the reason is that women had to face a lot of new challenges such as setting up the daily routine, taking care of the baby and so on, which could be a little overwhelming at first, but most of the women could cope with it. Actually, a lot of women said during the interventions, that they could not wait for their baby to be born, because afterwards, when they had their newborn in their arms, they had more direct clues on what they were doing wrong or right. Besides several women asked for psychological intervention before the last screening appointment, which also could be part of the lowered pathological rate.

Of course, it can also happen that women who felt a lot worse after delivery did not want to take part in the screening anymore and their missing EPDS questionnaires have a distorting effect on our results showing only slightly higher mean ranks and decreased pathological rate.

The pathological rate in our sample $(16.8 \%, 12.2 \%, 10.5 \%$ and $7.7 \%)$ differed in some ways from the ones in the meta-analysis of Gaynes et al. [16] (11\% in the first trimester, $8.5 \%$ in the second and third trimester and $9.7 \%$ in the postpartum period). Thus, it seems in the literature that depressed mood is the most common in the first trimester, then the prevalence decreases during later phases of the pregnancy, afterwards it increases after delivery. In our sample the prevalence is higher in all trimesters, but it decreases gradually, and it is lower in the postpartum phase compared to the meta-analysis [16]. In the background of this variation can be the cultural difference between studies or the used screening tool (none of the studies in the meta-analysis used the Hungarian version of the EPDS). It is also plausible that the screening program is in the background of these diversions. First, lots of women who needed and asked for help got adequate psychological support. Besides the screening program went on for years, which might have sensitized 
people to depressive symptoms in the healthcare system and in women's milieu too, thus women could have got more support from everywhere.

The pathological rate differed from some previous studies too, which were conducted in the area: in Szeged $10.8 \%, 6.9 \%, 6.5 \%$ and $7.8 \%$ [29] and $12 \%, 6 \%, 6.4 \%$ and $8.2 \%$ [24]; in Békéscsaba 9.3\%, 12.8\%, 9.3\% and 17.5\% [24] and 15.31\%, 14.29\%, 11.87\% and $12.68 \%$ [28] of women showed pathologic number of depressive symptoms in the first, second, third trimester and postpartum phase. These differences can be linked to the different sample size and demographic data.

When the antenatal phase was in focus, we found that $24 \%$ of women were depressed at least once from the three trimesters, according to the screening tool. This is somewhat more than $17.9 \%$, which was found in Bödecs's [19] study. We used different measuring tool on a bigger sample, which can explain the distinct results.

\subsection{EPDS scores and pre- and postpartum data}

\subsubsection{Mode of delivery}

Some studies found that the circumstances of the delivery can have an adverse effect on postpartum mood: some have found that delivering by cesarean section can increase the risk of postpartum depression [72-75]. We had similar results, namely cesarean section was connected to increased depressive scores in the postpartum period. This can be explained by various factors:

- after the cesarean section mothers usually cannot see their newborn as soon as women who had vaginal birth [75]

- their spouse cannot be in the delivery room, thus cannot support her [75]

- emergency cesarean section can be an unexpected and shocking experience for both the woman and her spouse [75]

- newborns are more likely to have neonatal problems when delivered by cesarean section [75]

- the cesarean section can increase the likelihood of intensified pain and infections in the postpartum period [75]

- besides during the interventions, after cesarean section, many women said that they thought that they were bad mother, who could not even bear her own child. They 
also mentioned the feeling of lack of control during the childbearing, which could also contribute to the higher EPDS scores.

There are also studies that have not found such difference in the depressive scores of the postpartum phase [76,77]. Between antenatal depression and cesarean section no connection was found in our sample, however, others have found that depression in late pregnancy is associated with higher risk of cesarean section [38].

\subsubsection{Protracted dilation and protracted descent}

To our knowledge no previous studies have analyzed if protracted dilation or protracted descent have any effect on mood in the postpartum phase. Our results suggested that women had higher depressive scores after delivery if any of these complications occurred during childbirth. In our opinion, it is possible that these difficulties made this event a more painful memory, when (as some women said later) they felt less self-confident and had decreased feeling of competence, some women were even truly afraid that they would not be able to deliver their child.

Tendency relationships are also important to mention, because - although they are not significant associations - they imply which connections should be further studied with stronger study settings. As protracted descent tendency and significant relationship were found in the second and third trimester too, thus it seems as if women who had protracted descent had higher depressive scores before delivery. This can be explained by depressive symptoms: a lot of energy is needed to give birth to the child, so if a woman feels fatigued, tired or exhausted [52], it's harder to make such an effort. Another depressive symptom can be hardship in thinking and concentrating [52], which can make cooperation with the medical staff more difficult. Besides feeling worthless, powerless or incapable [52] can also hinder the process.

\subsubsection{Preeclampsia}

Women who had preeclampsia during their pregnancies, were more likely to have higher depressive scores after delivery. Some previous studies have found similar results, although according to them, preeclampsia is not an independent risk factor for higher postpartum depressive scores. It has more to do with the consequences of this complication 
such as birth weight, mode of delivery, if admission to the neonatal intensive care unit is necessary and how long women or their newborns are hospitalized [78-80]. We did not find association between preeclampsia and antenatal depression, however other studies did so [39].

\subsubsection{Intrauterine growth restriction}

Earlier was found that depressive symptoms in the second and third trimester were associated with increased likelihood of having an IUGR fetus [44,81,82]. In our sample tendency relationships were found between higher depressive mean ranks and IUGR in the second and third trimester. As reported by Diego et al. [81] this might be mediated by the elevated cortisol level, either by directly reaching and affecting the fetus or it might change the placental environment. For example, the elevated cortisol level might cause decreased uterine artery blood flow, which might result in placental hypoxia, thus the fetus lacks oxygen and nutrients, which can lead to fetal growth restriction $[81,83]$. In our opinion, a reversed connection is also plausible: women's depressive scores could have also increased after getting the IUGR diagnosis, because they were stressed out with the possible consequences of it: women could have been afraid, that their child would have a serious disease, or even pass away before, during or after delivery. Although Grote et al. [44] found no significant association between antenatal depression and IUGR in their meta-analysis, they did find that if a woman was experiencing antenatal depression in a developing country, she was twice as likely to have an IUGR fetus compared to depressed pregnant women in Europe or in the USA.

\subsubsection{Low birthweight}

The results revealed that in our sample low birthweight was significantly associated with higher EPDS mean ranks in the second trimester. Besides, tendency associations were found between low birthweight and higher EPDS mean ranks in the third trimester and after delivery.

Some studies have found that antenatal depression is a significant risk factor for low birthweight [29,44,45,81,84], furthermore, according to Nasreen et al. [85] mothers with depressive symptoms were twice as likely to have a low birthweight infant compared to the women who did not have these symptoms. As stated by Diego et al. [81] low birthweight 
after antenatal depression can also be mediated by the increased maternal cortisol level. Besides antenatal depression and anxiety, low birthweight was associated with maternal malnutrition and poor economic status, furthermore negative connection was found between low birthweight and antepartum consultation, perinatal psychological support or family support, but the association with antenatal depression was independent of the effects of these factors [85]. Although a research in Pakistan has not found such a connection between depression and low birthweight [86].

\subsubsection{Gestational diabetes}

Nowadays diabetes mellitus counts as an endemic disease that does not spare pregnant women: earlier studies showed that the prevalence of GDM in Hungary was between 3.0$6.4 \%$ before the $21^{\text {th }}$ century [ 80 in reference to 81,82 ] and $9.29 \%$ in Tolna county between 2000 and 2007 [87]. In our sample $8.86 \%$ of women had GDM. Earlier it was found that women with GDM had higher state anxiety in the second trimester, as GDM is an additional complicating diagnosis [90], thus we hypothesized that GDM might also have an association with depressive symptoms. However, in our study no relationship was found between GDM and depressive scores, although in the study of Hinkle et al. [40] there was an association between them both in the antepartum and the postpartum phase. Behind this relationship might stand inflammation: according to the review of Robakis et al. [91], there is an overlap between the inflammatory profile of GDM and depression, which should be further analyzed to have a clearer picture of this association.

\subsubsection{Preterm birth}

We did not find significant relationship between preterm birth and depressive scores, while other studies did find that antenatal depression was associated to preterm birth $[42,44,81,82]$, with elevated cortisol level as a moderating factor [81,92].

Many of these complications can have long term effects on the descendant, for example preterm birth was associated with increased childhood mortality and diminished reproductivity in adulthood [93]. Complications can also influence health care charges: as birth weight and gestational age at birth decreased, the charges for hospitalization increased [94]. 
It is also important to mention that women who are socioeconomically disadvantaged are in double threat: they have an increased risk to become depressed and have a perinatal complication. Furthermore, they are less likely to be accurately diagnosed and usually they have less chance to have access to accurate mental health services [44].

\subsection{Relation between the antepartum and the postpartum EPDS scores}

Leigh and Milgrom [35] found earlier that antepartum depression is a strong predictor for postpartum depression. Our results showed weak to moderate positive correlations between the EPDS scores of the measuring occasions implying that depressive scores were quite stable: women who had higher depressive scores in the earlier measuring occasions were more likely to have higher scores later as well and vice versa.

We also ran this analysis separately on the intervention and non-intervention groups to see if anything changes. The results showed the same tendency in the non-intervention group, namely all EPDS scores correlated with each other significantly, positively, with weak and moderate correlation. Although when the intervention group was in focus, only the EPDS scores of the second and third trimester correlated significantly, which implies that the depressive scores varied more in this group.

\subsection{Associations with intervention}

After the correlation analysis we examined how different the EPDS scores of the intervention and non-intervention groups were from each other, what was in the background of this variability. At first, we analyzed the difference between the before intervention and after intervention EPDS ranks and found significant decrease. Previous studies also found that intervention could help reducing depressive symptoms [60]. This is especially meaningful, because according to van Schaik et al. [95], most women preferred psychotherapy to antidepressant medication, especially among postpartum women [96].

We analyzed if there was a difference in the EPDS mean ranks between women who started the intervention in different trimesters or did not attend it at all. The results showed that the lowest EPDS ranks were in the non-intervention group implying that they had some problems, some symptoms too, but in most cases, they could cope with them. In almost all intervention groups, those EPDS mean ranks were the highest when women started the intervention. In our opinion, this implies that all women could cope with some of their 
problems along the way, but when they felt the most overwhelmed, they asked for help. This looks promising, because not every problem needs professional support, as we could see in the non-intervention group, but when there was a need, some women had confidence, strength and determination to ask for help. After women attended the interventions, their EPDS mean ranks tended to decrease in all the following measuring occasions [68]. Milgrom et al. [56] found that the women who attended antenatal psychological interventions had lower depressive scores in the postpartum phase compared to women, who did not attend it. In our sample this was not the case, however, the EPDS mean ranks of the groups starting the intervention in the first and second trimester, did not differ significantly from the EPDS mean ranks of the non-intervention group. This implies that the sooner started antenatal psychological interventions could help in a much more intensive way preventing postpartum depression [68], which was concluded in Dennis and Hodnett's [57] review too.

The overall highest EPDS mean rank was in the first trimester of the first-trimesterintervention-group. We think that mostly the women attended the intervention so early, whose pregnancy was unplanned, and they did not know whether they wanted to keep the fetus or not. It is quite hard and stressful to decide over a new life, which could increase depressive symptoms.

In the literature, about $6.5 \%$ of the identified depressed women asked for professional help [97], in our sample $23.5 \%$ did. This difference may be due to the fact that in Hungary women usually have a good relationship with their perinatal nurses, they trust them and during the screening program these perinatal nurses suggested women exhibiting possible depressive symptoms should seek professional help. However, still less than one quarter of the women with high EPDS scores contacted the psychologist. This might be- as women in the intervention group often mentioned - because, in Hungary there is still a stigma against seeking psychotherapy. Most people are still afraid that others would think they are incompetent or even mentally challenged if they ask for psychological help [68]. It is not helpful, either, that extreme and violent psychotic symptoms and behavior are associated with postpartum depression in the media, which makes women confuse the two conditions; therefore, they refuse to ask for help as they do not want to be associated with such intense acts, aberrant behavior. Public education focusing on the differences between the two conditions might help to reverse this negative tendency [68,98].

When pre- and peripartum complications and intervention were in focus no significant relationship was found. This can be promising, because EPDS ranks were higher in all the 
intervention groups in some cases significantly higher) compared to the non-intervention group and, as we presented earlier, some of the complications were associated with higher EPDS ranks. The fact that the statistical analysis revealed no associations with the complications (although women had higher EPDS mean ranks in the intervention groups) might mean that psychological intervention can provide some kind of protective factor against these negative outcomes, but of course, to come to such conclusion further and deeper studies are needed [68].

When mode of delivery and intervention was in focus an interesting result appeared: the women who started the interventions during their pregnancies were significantly less likely to have cesarean section compared to women in the non-intervention group. Laursen, Johansen and Hedegaard [99] found earlier that women with fear of the actual delivery were more likely to have a protracted labor and an emergency cesarean section During the interventions some women talked about their fears of giving birth, which became the focus for some of the following consultations. In our opinion, it is possible, that these psychoeducational consultations might lead to less stressful deliveries with less cesarean sections, but of course, further studies are needed to determine the consultations' contribution [68].

It is also important to mention that psychological intervention is not available for, or desired by everybody; in these cases, professionals should consider pharmacological treatment for antenatal depression in hope of preventing or avoiding some of the possible perinatal complications and postpartum depression [44].

\subsection{Associations with demographic variables}

When EPDS mean ranks and demographic data were in focus, our results were similar to previous findings. Just like previously [28-33] more or more severe depressive symptoms, thus higher depressive scores were related to unplanned pregnancy and being single or widowed, which can be understood, because raising a child is great responsibility, it has it costs and it can be even harder if the mother-to-be is single or without family support. Even if "unplanned" does not necessarily mean "unwelcome", women still have to cope with the ramifications of this event, which will have effect on the rest of their lives [98]. On the other hand, deciding on abortion can cause feeling of guilt, because a life is taken away. Although these associations were only significant in the antepartum period, which might imply that (as their pregnancies progressed) women learned how to cope with their 
difficulties, like where or who to ask for support. That is important, because as Singh and Mahapatra [100] reported, unplanned pregnancy was significantly associated with risk behavior and inadequate prenatal care.

Younger or older age were also associated to higher depressive scores [19,28,29,32,33]; in the present analysis 26-35 years old seems to be the ideal age to be pregnant, if depressive scores are in focus. Being younger might be a risk factor, because usually more time is needed for financial stability, besides unplanned pregnancy rate is higher in the 16-19 years old group than in the elder groups [101]. While being older might evoke questions whether they will have enough energy to raise a/another child or they could be afraid of the higher rates of complications [102].

In earlier studies primiparity was found to be a protective factor [29,30]. In our sample primiparas had lower EPDS mean ranks during pregnancy; while in the postpartum period they had the higher EPDS mean ranks, and only this difference was significant. This change in the tendency could be because multipara women had to take care of their other children, thus it could be harder to concentrate on the positive aspects of their pregnancies, like their relationship with their fetus [29]. Besides, if there was a complication during the previous pregnancy it could have caused further distress [29]. However, in the postpartum

period the tendency can change: multipara women are still busier, but they have already had experience how to take care of a newborn, how to set up a new routine in their life, and so on. Primipara women lack this experience, which can make this time more difficult for them.

According to our results, the women were more likely to come to the interventions, whose pregnancy were unplanned and who were widowed or single. This seems to be understandable, because these groups had the higher EPDS ranks, so they must have felt more overwhelmed with their difficulties.

\subsection{Other approaches, further research possibilities}

When we talk about depression, we mostly think of a single condition that has several symptoms which can be interchanged and are equally good indicators. Thus, we sum up the severity of these symptoms, and the sum-score reveals the severity of the disorder [103]. Several researchers started to analyze the EPDS questionnaire with a different approach: they searched for latent factors among the questions of the screening tool. In our study [104] we used confirmatory factor analysis, a model confirmatory approach to analyze 
these previously found factors (including the ones found earlier on a smaller Hungarian sample by some of our authors $[25,26])$ on our big Hungarian sample. In our sample we had the data of 2967 pregnant women, whose gestational age was between 12 and 30 weeks, and 714 women's after delivery EPDS scores. We also created our six own theory-driven models on which questions might constitute the different factors. Our first model (M1) included "anhedonia" factor (EPDS items 1, 2), "anxiety" factor (items 3, 4, 5) and "low mood" factor (items 8,9). Our second and third model were similar, but we used the "hopelessness" factor (items 6, 10) instead of "low mood" (M2), or both (M3). We also created another "anxiety" factor without item 3 (guilt), because we thought it might not fit in well enough. Thus, our fourth model (M4) included "anhedonia" (items 1, 2), "anxiety" (items 4, 5), "low mood" (items 8, 9), and a fourth, "suicidal risk" factor (items 3, 6 and 10 as in guilt, helplessness, and self-harm thoughts). The fifth model was like M4, but we removed the "suicidal risk" factor (M5: the "anhedonia" factor, the "anxiety" factor with two items and "low mood"). Finally, our sixth model was like M5, but we replaced the "low mood" factor with the "suicidal risk" factor (M6).

According to our results, our best fitting model was M5 in the antepartum period and M6 (closely followed by M5) in the postpartum phase. Only few of the previously found models fit a little better in some aspects, but our best model showed the best overall fit with the data [104].

To our knowledge, ours was the first of these studies, that conducted confirmatory factor analysis model approach to examine all previously published factors on one big sample. To our knowledge, we were also the first ones who reexamined previously found factors in the same population area, but on a bigger sample [104].

It would be productive and promising if further research could analyze whether the mentioned factors are associated with pre- and peripartum complications, mode of delivery, demographic data or psychological intervention.

\section{Conclusion}

Our first objective was to assess the relationship between pre- and peripartum complications, demographic data and EPDS scores. Our results were the following:

- significantly higher EPDS mean ranks were associated with

- cesarean section (in the postpartum phase)

$\circ$ protracted dilation (in the postpartum phase) 
- protracted descent (in the third trimester and postpartum phase)

○ low birthweight (in the second trimester)

- tendency relationships were found between higher EPDS mean ranks and

- IUGR (in the second and third trimester)

○ low birthweight (in the third trimester and postpartum period)

$\circ$ protracted descent (in the second trimester)

- no relationship was found between higher EPDS mean ranks and

○ premature birth

○ GDM.

With demographic data the following results were found:

- significantly higher EPDS mean ranks were associated with

○ unplanned pregnancy (in all trimesters)

$\circ$ being single, divorced or widowed (in the first and second trimester)

○ having the first child (in the postpartum phase)

$\circ$ being younger than 21 years old or older than 35 years old (in all trimesters)

- tendency relationship was found between higher EPDS mean rank and

$\circ$ unplanned pregnancy (in the postpartum phase)

Our second objective was to assess the pathological rate in our South-Hungarian sample and explore how EPDS scores varied during the pre- and postpartum phase. According to our results the first trimester seemed to be the most problematic phase with the highest pathological rate; after this time the pathological rate decreased in all the measuring occasions, which result differs from the ones in the literature. The pathological rate in the postpartum phase is lower compared to the results of previous studies.

We also found that EPDS scores are quite stable: antenatal and postnatal depressive scores correlated with each other positively, with weak or moderate correlation.

These findings, namely the stability of depressive scores over time, and their association to pre- and peripartum complications and mode of delivery, emphasize the importance of the pre- and postpartum depression screening program. As from now on we can identify women with higher EPDS scores, who are more likely to have some of the aforementioned complications. 
Our third objective was to explore how psychological intervention was related to pre- and peripartum complications, mode of delivery, EPDS scores and demographic data. According to our findings the after-intervention scores were significantly lower compared to the before-intervention scores, which implied the suitability of the used approaches. Besides we found, that the EPDS scores of women who came to the interventions, were the highest when they started the psychological sessions. According to our explanation this might mean that women could cope with their difficulties for a while, but when problems got overwhelming, some women wanted to seek for support. From our sample only $23.5 \%$ of women, to whom the intervention was offered, asked for support. This shed light on the importance of (psycho)education: it is essential to educate people to ask for professional help without feeling ashamed, when they are experiencing overwhelming hard times in their lives.

When demographic data were in focus: the women came to the interventions more likely, who were single, divorced or widowed, or who carried unplanned pregnancy. As these women tend to have higher depressive scores, in our explanation it is understandable that they are more likely to ask for help.

When pre- and peripartum complications were in focus, no significant difference was found between the intervention and non-intervention groups. This can be promising, because women in the intervention group had higher depressive scores, thus more complications could be excepted in this group based on the EPDS score and pre- and peripartum complications findings. Besides, women who attended interventions during the antenatal phase were less likely to have cesarean section compared to women in the non-intervention group, which might imply that psychological support can be a protective factor against this operative delivery.

These findings emphasize the importance of the psychological intervention, as part of the pre- and postpartum depression screening program, to provide professional assistance to anybody who feels the need for support when having problems during this certain period of her life.

\section{New statements of the study}

Our study results showed significant relationships between pre- and peripartum complications, mode of delivery and EPDS scores; besides the results implied the effectiveness of psychological interventions in reducing depressive scores and the rate of 
cesarean sections. All these emphasize the importance of the pre- and postpartum depression screening procedure and providing psychological support to women who need it.

It would be desirable this screening program should become a routine procedure in Hungary. This way we could conduct more and more detailed studies to find more specific relationships between depressive scores, psychological interventions and pre- and peripartum data. Besides, this way psychological support could become more available for every pregnant and postpartum woman who struggles with various difficulties during this time.

\section{Acknowledgements}

I would like to express my gratitude to my supervisor, Dr. Töreki Annamária, for her support, motivation and patience during the research and the writing of this thesis.

We would like to say thank you to all the perinatal nurses who have obtained the questionnaire from the participating women. Without their essential help, this study could not exist. In addition, we would like to thank all the employees of the University of Szeged Department of Obstetrics and Gynecology who have contributed to the study in any way. 


\section{References}

1. Belső N. Társadalom, kultúra, női szerepek. In: C. Molnár E, Füredi J, Papp Z (eds.). Szülészet-nőgyógyászati pszichológia és pszichiátria. Budapest: Medicina Kiadó Rt.; 2006. p. 47-53.

2. Dornelles LMN, MacCallum F, Lopes R de CS, Piccinini CA, Passos EP. 'Living each week as unique': Maternal fears in assisted reproductive technology pregnancies. Midwifery. 2014;30(3): e115-20.

3. Belső N. A perinatális időszak pszichés zavarai. In: C. Molnár E, Füredi J, Papp Z (eds.). Szülészet-nőgyógyászati pszichológia és pszichiátria. Budapest: Medicina Kiadó Rt.; 2006. p. 81-93.

4. Martini J, Asselmann E, Einsle F, Strehle J, Wittchen H-U. A prospectivelongitudinal study on the association of anxiety disorders prior to pregnancy and pregnancy- and child-related fears. J Anxiety Disord. 2016;40: 58-66.

5. Barker DJ. Fetal origins of coronary heart disease. BMJ. 1995;311(6998): 171-4.

6. Goodman JH, Chenausky KL, Freeman MP. Anxiety Disorders During Pregnancy: A Systematic Review. J Clin Psychiatry. 2014;75(10): 1153-84.

7. Vesga-López O, Blanco C, Keyes K, Olfson M, Grant BF, Hasin DS. Psychiatric disorders in pregnant and postpartum women in the United States. Arch Gen Psychiatry. 2008;65(7): 805-15.

8. Bödecs T, Horváth B, Szilágyi E, Diffelné Németh M, Sándor J. Associations of trait anxiety, depression, self-esteem and social capital with health behaviour in early pregnancy. [A szorongás, a depresszió, az önértékelés és a társadalmi tőke összefüggései a várandósok egészségmagatartásával]. Mentálhig És Pszichoszomatika. 2010;11: 17-30.

9. Ross LE, Murray BJ, Steiner M. Sleep and perinatal mood disorders: a critical review. J Psychiatry Neurosci. 2005;30(4): 247-56.

10. Pitt B. „Maternity blues”. Br J Psychiatry J Ment Sci. 1973;122(569): 431-3.

11. Henshaw C. Mood disturbance in the early puerperium: a review. Arch Womens Ment Health. 2003;6(2): 33-42.

12. Beck CT. Postpartum depression: it isn't just the blues. Am J Nurs. 2006;106(5): 4050; quiz 50-1.

13. Kennerley H, Gath D. Maternity blues. I. Detection and measurement by questionnaire. Br J Psychiatry J Ment Sci. 1989;155: 356-62. 
14. Doucet S, Jones I, Letourneau N, Dennis C-L, Blackmore ER. Interventions for the prevention and treatment of postpartum psychosis: a systematic review. Arch Womens Ment Health. 2011;14(2): 89-98.

15. American Psychiatric Association, ed. Diagnostic and statistical manual of mental disorders: DSM-IV. 4. ed., 7. print. Washington, DC; 1998.

16. Gaynes BN, Gavin N, Meltzer-Brody S, Lohr KN, Swinson T, Gartlehner G, et al. Perinatal depression: prevalence, screening accuracy, and screening outcomes. Evid Rep Technol Assess (Summ). 2005;(119): 1-8.

17. Marcus SM. Depression during pregnancy: rates, risks and consequences--Motherisk Update 2008. Can J Clin Pharmacol J Can Pharmacol Clin. 2009;16(1): e15-22.

18. McGarry J, Kim H, Sheng X, Egger M, Baksh L. Postpartum depression and helpseeking behavior. J Midwifery Womens Health. 2009;54(1): 50-6.

19. Bödecs T. Negative effects and possible mechanisms of antenatal depression, anxiety and self-esteem on neonatal outcomes. PhD Thesis. [A várandósság alatti depresszió, szorongás és önértékelés neonatális kimenetelekre gyakorolt negatív hatásainak vizsgálata, és a lehetséges mechanizmusok feltárása. PhD-tézis.] [Internet]. [Pécsi Tudományegyetem, Egészségtudományi Kar]; 2010. Available: ttp://ltsp.etk.pte.hu/portal/wp/File/Doktoriiskola/Tezisfuzetek/Ertekezes_BodecsTa mas.pdf

20. Kopp M, Szedmák S, Lőke J, Skrabski Á. The prevalence of depressive symptoms and its relevance in the health care in the Hungarian population. [A depressziós tünetegyüttes gyakorisága és egészségügyi jelentősége a magyar lakosság körében.]. Lege Artis Med. 1997;7(3): 136-44.

21. Kopp M, Skrabski Á. Men's and women's health conditions in Hungary. [Nők és férfak egészségi állapota Magyarországon]. In: Nagy I, Pongrácz T, szerkesztő. Role changes A report of men's and women's situation 2009 [Szerepváltozások Jelentés nők és férfak helyzetéről 2009]. Budapest: TÁRKI - Szociális és Munkaügyi Minisztérium; 2009. p. 117-136.

22. Rózsa S, Szádóczky E, Füredi J. Psychometric properties of the Hungarian version of the shortened Beck Depression Inventory. Psychiatr Hung. 2001;16: 384-402.

23. Kopp M, Czakó L, Skrabski Á. Suggested methodology for comparative mental health researches [Összehasonlító mentálhigiénés vizsgálatokhoz ajánlott módszertan]. Végeken. 1990;1(2): 4-24. 
24. Töreki A, Baloghné Fürész V, Szenti Z, Szeberényi Z, Becsei L, Pál A. The psychological screening process in the maternal care system. [A pszichológiai szürés megjelenése a várandósgondozásban.]. Magy Nőorvosok Lapja. 2014;77(6): 12-5.

25. Töreki A, Andó B, Keresztúri A, Sikovanyecz J, Dudas R, Janka Z, et al. The Edinburgh Postnatal Depression Scale: translation and antepartum validation for a Hungarian sample. Midwifery. 2013;29: 308-15.

26. Töreki A, Andó B, Dudas RB, Dweik D, Janka Z, Kozinszky Z, et al. Validation of the Edinburgh Postnatal Depression Scale as a screening tool for postpartum depression in a clinical sample in Hungary. Midwifery. 2014;30: 911-8.

27. Cox JL, Holden JM, Sagovsky R. Detection of postnatal depression. Development of the 10-item Edinburgh Postnatal Depression Scale. Br J Psychiatry J Ment Sci. 1987;150: 782-6.

28. Hompoth EA, Gálosi N, Becsei L, Töreki A. Pszichológiai szürés a várandósgondozásban: eredmények Békéscsaba körzetéből [Psychological screening in the pregnancy care: results from the area of Békéscsaba]. Orv Hetil. 2020;161(10): 380-7.

29. Hompoth EA, Töreki A, Baloghné Fürész V, Németh G. A hangulati állapot alakulásának kockázati tényezői a perinatalis időszakban | The risk factors of mood changing during the perinatal period. Orv Hetil. 2017;158: 139-46.

30. Dudas R, Csatordai S, Devosa I, Töreki A, Andó B, Barabás K, et al. Obstetric and psychosocial risk factors for depressive symptoms during pregnancy. Psychiatry Res. 2012;200: 323-8.

31. Kozinszky Z, Dudas RB, Csatordai S, Devosa I, Tóth É, Szabó D, et al. Social dynamics of postpartum depression: a population-based screening in South-Eastern Hungary. Soc Psychiatry Psychiatr Epidemiol. 2011;46(5): 413-23.

32. Töreki A. Psychosocial risk factors and screening options for perinatal psychopathologies. PhD Thesis [A perinatális pszichopatológiák kialakulását elősegítő pszichoszociális faktorok és szürési lehetőségeik. PhD-tézis.]. Department of Obstetrics and Gynaecology, Albert Szent-Györgyi Medical Center, University of Szeged, Szeged Szegedi Tudományegyetem, SzentGyörgyi Albert Klinikai Központ, Szülészeti és Nőgyógyászati Klinika, Szeged; 2012.

33. Lee A, Keung Lam S, Mun Lau SM S, Chong C, Chui A, Fong D. Prevalence, course, and risk factors for antenatal anxiety and depression. Obstet Gynecol. 2007;110: $1102-12$. 
34. Ludermir A, Lewis G, Alves Valongueiro S, Araújo T, Araya R. Violence against women by their intimate partner during pregnancy and postnatal depression: A prospective cohort study. Lancet. 2010;376: 903-10.

35. Leigh B, Milgrom J. Risk factor for antenatal depression, postnatal depression and parenting stress. BMC Psychiatry. 2008;8: 24-35.

36. Ding T, Wang D-X, Qu Y, Chen Q, Zhu S-N. Epidural labor analgesia is associated with a decreased risk of postpartum depression: a prospective cohort study. Anesth Analg. 2014;119(2): 383-92.

37. Boudou M, Teissèdre F, Walburg V, Chabrol H. Relation entre l'intensité de la douleur de l'accouchement et celle du postpartum blues [Association between the intensity of childbirth pain and the intensity of postpartum blues]. L'Encephale. 2007;33(5): 805-10.

38. Chung TK, Lau TK, Yip AS, Chiu HF, Lee DT. Antepartum depressive symptomatology is associated with adverse obstetric and neonatal outcomes. Psychosom Med. 2001;63(5): 830-4.

39. Cripe SM, Frederick IO, Qiu C, Williams MA. Risk of Preterm Delivery and Hypertensive Disorders of Pregnancy in Relation to Maternal Comorbid Mood and Migraine Disorders during Pregnancy. Paediatr Perinat Epidemiol. 2011;25(2): 11623.

40. Hinkle SN, Buck Louis GM, Rawal S, Zhu Y, Albert PS, Zhang C. A longitudinal study of depression and gestational diabetes in pregnancy and the postpartum period. Diabetologia. 2016;59(12): 2594-602.

41. Zuckerman B, Amaro H, Bauchner H, Cabral H. Depressive symptoms during pregnancy: relationship to poor health behaviors. Am J Obstet Gynecol. 1989;160(5 Pt 1): 1107-11.

42. Jesse DE, Seaver W, Wallace DC. Maternal psychosocial risks predict preterm birth in a group of women from Appalachia. Midwifery. 2003;19(3): 191-202.

43. Qiao Y, Wang J, Li J, Wang J. Effects of depressive and anxiety symptoms during pregnancy on pregnant, obstetric and neonatal outcomes: A follow-up study. J Obstet Gynaecol. 2012;32(3): 237-40.

44. Grote NK, Bridge JA, Gavin AR, Melville JL, Iyengar S, Katon WJ. A meta-analysis of depression during pregnancy and the risk of preterm birth, low birth weight, and intrauterine growth restriction. Arch Gen Psychiatry. 2010;67(10): 1012-24. 
45. Rahman A, Bunn J, Lovel H, Creed F. Association between antenatal depression and low birthweight in a developing country. Acta Psychiatr Scand. 2007;115(6): 4816.

46. Righetti-Veltema M, Conne-Perréard E, Bousquet A, Manzano J. Postpartum depression and mother-infant relationship at 3 months old. J Affect Disord. 2002;70(3): 291-306.

47. Hübner-Liebermann B, Hausner H, Wittmann M. Recognizing and Treating Peripartum Depression. Dtsch Arztebl Int. 2012;109(24): 419-24.

48. Field T. Postpartum depression effects on early interactions, parenting, and safety practices: A review. Infant Behav Dev. 2010;33(1): 1-6.

49. Koutra K, Chatzi L, Bagkeris M, Vassilaki M, Bitsios P, Kogevinas M. Antenatal and postnatal maternal mental health as determinants of infant neurodevelopment at 18 months of age in a mother-child cohort (Rhea Study) in Crete, Greece. Soc Psychiatry Psychiatr Epidemiol. 2013;48(8): 1335-45.

50. Hay DF, Pawlby S, Waters CS, Sharp D. Antepartum and postpartum exposure to maternal depression: different effects on different adolescent outcomes. J Child Psychol Psychiatry. 2008;49(10): 1079-88.

51. Pawlby S, Hay D, Sharp D, Waters C, O'Keane V. Antenatal depression predicts depression in adolescent offspring: Prospective longitudinal community-based study. J Affect Disord. 2008;113: 236-43.

52. American College of Obstetricians and Gynaecologists (ACOG). Use of psychiatric medications during pregnancy and lactation Clinical Practice Guidelines [Internet]. Vol. ACOG practice bulletin; Iss. 92. Washington (DC); 2008 [Cite 2018. June 30.]. Available: $\quad$ https://www.guidelinecentral.com/summaries/use-of-psychiatricmedications-during-pregnancy-and-lactation/

53. Berle JO, Spigset O. Antidepressant use during breastfeeding. Curr Womens Health Rev. 2011;7: 28-34.

54. Bader A, Frisch U, Wirz-Justice A, Riecher-Rössler A. Schwangerschaftsdepression und deren Behandlung. Nervenarzt. 2010;81(3): 267-76.

55. Wen SW, Walker M. The use of selective serotonin reuptake inhibitors in pregnancy. J Obstet Gynaecol Can JOGC J Obstet Gynecol Can JOGC. 2004;26(9): 819-22.

56. Milgrom J, Schembri C, Ericksen J, Ross J, Gemmill AW. Towards parenthood: an antenatal intervention to reduce depression, anxiety and parenting difficulties. J Affect Disord. 2011;130(3): 385-94. 
57. Dennis C-L, Hodnett E. Psychosocial and psychological interventions for treating postpartum depression. Cochrane Database Syst Rev. 2007;(4): CD006116.

58. O'Hara MW, Stuart S, Gorman LL, Wenzel A. Efficacy of interpersonal psychotherapy for postpartum depression. Arch Gen Psychiatry. 2000;57(11): 103945.

59. O’Mahen H, Fedock G, Henshaw E, Himle JA, Forman J, Flynn HA. Modifying CBT for Perinatal Depression: What Do Women Want?: A Qualitative Study. Cogn Behav Pract. 2012;19(2): 359-71.

60. Chang M-Y, Chen C-H, Huang K-F. Effects of music therapy on psychological health of women during pregnancy. J Clin Nurs. 2008;17(19): 2580-7.

61. Saisto T, Toivanen R, Salmela-Aro K, Halmesmäki E. Therapeutic group psychoeducation and relaxation in treating fear of childbirth. Acta Obstet Gynecol Scand. 2006;85(11): 1315-9.

62. Tabb KM, Choi S, Pineros-Leano M, Meline B, McDonald HG, Kester R, et al. Perinatal depression screening in a Women, Infants, and Children (WIC) program: perception of feasibility and acceptability among a multidisciplinary staff. Gen Hosp Psychiatry. 2015;37(4): 305-9.

63. Buist AE, Milgrom J, Barnett BEW, Pope S, Condon JT, Ellwood DA, et al. To screen or not to screen - that is the question in perinatal depression. Med J Aust. 200;177(7): 101-5.

64. Boyd RC, Le HN, Somberg R. Review of screening instruments for postpartum depression. Arch Women's Ment Health. 2005;8(3): 141-53.

65. Liu YC, Blair E. Predicted Birthweight for Singletons and Twins. Twin Res. 2003;5(6): 529-37.

66. Rauh-Hain JA, Rana S, Tamez H, Wang A, Cohen B, Cohen A, et al. Risk for developing gestational diabetes in women with twin pregnancies. J Matern Fetal Neonatal Med. 2009;22(4): 293-9.

67. Martin JA, Hamilton BE, Sutton P, Ventura SJ, Menacker F, Kirmeyer S, et al. Births: Final Data for 2006. Natl Vital Stat Rep. 2009;57(7):1-104.

68. Hompoth EA, Pető Z, Fürészné Balogh V, Töreki A. Associations Between Depression Symptoms, Psychological Intervention and Perinatal Complications. J Clin Psychol Med Settings. 2020;27(1): 199-205.

69. Hungarian Ministry of Human Resources. Professional protocol of the Hungarian Ministry of Human Resources about the roles of perinatal nurses in pregnancy care 
[Az Egészségügyi Minisztérium szakmai protokollja a védőnő feladatairól a várandós gondozásban]. Sanit Gaz Egészségügyi Közlöny. 2008;58(3): 1616-31.

70. Hungarian Ministry of Human Resources. Professional protocol of the Hungarian Ministry of Human Resources about the mother-baby-father unit treatment of mental disorders during the pre- peri- and postnatal phase $[\mathrm{Az}$ Emberi Eröforrások Minisztériuma szakmai irányelve a pre-, peri- és posztnatális mentális zavarok babamama-papa egységében történő kezeléséről]. Sanit Gaz Egészségügyi Közlöny. 2017;66(4): 1120-67.

71. García-Enguídanos A, Calle ME, Valero J, Luna S, Domínguez-Rojas V. Risk factors in miscarriage: a review. Eur J Obstet Gynecol Reprod Biol. 2002;102(2): $111-9$.

72. Xie R, Lei J, Wang S, Xie H, Walker M, Wen SW. Cesarean section and postpartum depression in a cohort of Chinese women with a high cesarean delivery rate. $\mathbf{J}$ Womens Health 2002. 2011;20(12): 1881-6.

73. Yang S-N, Shen L-J, Ping T, Wang Y-C, Chien C-W. The delivery mode and seasonal variation are associated with the development of postpartum depression. $\mathrm{J}$ Affect Disord. 2011;132(1-2): 158-64.

74. Fisher J, Astbury J, Smith A. Adverse psychological impact of operative obstetric interventions: a prospective longitudinal study. Aust N Z J Psychiatry. 1997;31(5): 728-38.

75. Kovácsné Török Z. Psychiatric disorders associated to childbirth, especially postpartum depression. $\mathrm{PhD}$ thesis. [Szüléshez társuló pszichiátriai zavarok, különös tekintettel a gyermekágyi lehangoltság kérdéskörére. $\mathrm{PhD}$ tézis.]. Debreceni Egyetem; 2009.

76. Goker A, Yanikkerem E, Demet MM, Dikayak S, Yildirim Y, Koyuncu FM. Postpartum depression: is mode of delivery a risk factor? ISRN Obstet Gynecol. 2012;2012: 616759 .

77. Lucic M. Incidence of Postpartum Depression After Cesarean Section Versus Normal Delivery [Thesis]. Pacific University School of Physician Assistant Studies; 2013.

78. Hoedjes M, Berks D, Vogel I, Franx A, Bangma M, Darlington A-SE, et al. Postpartum depression after mild and severe preeclampsia. J Womens Health 2002. 2011;20(10): 1535-42. 
79. Abedian Z, Soltani N, Mokhber N, Esmaily H. Depression and anxiety in pregnancy and postpartum in women with mild and severe preeclampsia. Iran J Nurs Midwifery Res. 2015;20(4): 454-9.

80. Vigod SN, Villegas L, Dennis C-L, Ross LE. Prevalence and risk factors for postpartum depression among women with preterm and low-birth-weight infants: a systematic review. BJOG Int J Obstet Gynaecol. 2010;117(5): 540-50.

81. Diego MA, Field T, Hernandez-Reif M, Schanberg S, Kuhn C, Gonzalez-Quintero VH. Prenatal Depression Restricts Fetal Growth. Early Hum Dev. 2009;85(1): 6570.

82. Sabri Y, Nabel H. The impact of anxiety and depression during pregnancy on fetal growth and the birth outcome. 2015;36(95).

83. Dugoff L, Lynch AM, Cioffi-Ragan D, Hobbins JC, Schultz LK, Malone FD, et al. First trimester uterine artery Doppler abnormalities predict subsequent intrauterine growth restriction. Am J Obstet Gynecol. 2005;193(3 Pt 2): 1208-12.

84. Accortt EE, Cheadle ACD, Dunkel Schetter C. Prenatal depression and adverse birth outcomes: an updated systematic review. Matern Child Health J. 2015;19(6): 130637.

85. Nasreen HE, Kabir ZN, Forsell Y, Edhborg M. Low birth weight in offspring of women with depressive and anxiety symptoms during pregnancy: results from a population based study in Bangladesh. BMC Public Health. 2010;10: 515-24.

86. Husain N, Munshi T, Jafri F, Husain M, Parveen A, Saeed Q, et al. Antenatal Depression is Not Associated with Low-Birth Weight: A Study from Urban Pakistan. Front Psychiatry. 2014;5: 175-80.

87. Kun A. A gestatios diabetesz mellitus szürése, és a szürés során mért C-peptid szint szülészeti jelentősége. [PhD Thesis]: Pécsi Tudományegyetem; 2011.

88. Földesi I. A GDM szürése és diagnosztikája. Diabetol Hung. 2005;13(2): 32-8.

89. Pátkay J, Varga Szabó L, Medve L. Gestatios diabetes szürés Dunaújvárosban. Tíz év eredményei, tapasztalatai. Magy Belorv Arch. 1995;48: 169-71.

90. Daniells S, Grenyer BFS, Davis WS, Coleman KJ, Burgess J-AP, Moses RG. Gestational Diabetes Mellitus: Is a diagnosis associated with an increase in maternal anxiety and stress in the short and intermediate term? Diabetes Care. 2003;26(2): $385-9$. 
91. Robakis TK, Aasly L, Williams KE, Clark C, Rasgon NL. Roles of Inflammation and Depression in the Development of Gestational Diabetes. Curr Behav Neurosci Rep. 2017;4(4): 369-83.

92. Sandman CA, Glynn L, Schetter CD, Wadhwa P, Garite T, Chicz-DeMet A, et al. Elevated maternal cortisol early in pregnancy predicts third trimester levels of placental corticotropin releasing hormone $(\mathrm{CRH})$ : priming the placental clock. Peptides. 2006;27(6): 1457-63.

93. Swamy GK, Ostbye T, Skjaerven R. Association of preterm birth with long-term survival, reproduction, and next-generation preterm birth. JAMA. 2008;299(12): 429-36.

94. Cuevas KD, Silver DR, Brooten D, Youngblut JM, Bobo CM. Hospital Charges at Birth and Frequency of Rehospitalizations and Acute Care Visits over the First Year of Life. Am J Nurs. 2005;105(7): 56-65.

95. Schaik D, F.J. Klijn A, Hout H, Van Marwijk H, T.F. Beekman A, de Haan M, et al. Patients' preferences in the treatment of depressive disorder in primary care. Gen Hosp Psychiatry. 2004;26(3): 184-9.

96. Whitton A, Warner R, Appleby L. The pathway to care in post-natal depression: Women's attitudes to post-natal depression and its treatment. Br J Gen Pract J R Coll Gen Pract. 1996;46: 427-8.

97. Goodman JH. Women's attitudes, preferences, and perceived barriers to treatment for perinatal depression. Birth Berkeley Calif. 2009;36(1): 60-9.

98. Beck CT. Predictors of postpartum depression: an update. Nurs Res. 2001;50(5): $275-85$.

99. Laursen M, Johansen C, Hedegaard M. Fear of childbirth and risk for birth complications in nulliparous women in the Danish National Birth Cohort. BJOG Int J Obstet Gynaecol. 2009;116(10): 1350-5.

100. Singh A, Singh A, Mahapatra B. The consequences of unintended pregnancy for maternal and child health in rural India: evidence from prospective data. Matern Child Health J. 2013;17(3): 493-500.

101. Wellings K, Jones KG, Mercer CH, Tanton C, Clifton S, Datta J, et al. The prevalence of unplanned pregnancy and associated factors in Britain: findings from the third National Survey of Sexual Attitudes and Lifestyles (Natsal-3). Lancet. 2013;382(9907): 1807-16. 
102. Yaniv SS, Levy A, Wiznitzer A, Holcberg G, Mazor M, Sheiner E. A significant linear association exists between advanced maternal age and adverse perinatal outcome. Arch Gynecol Obstet. 2011;283(4): 755-9.

103. Fried EI, Nesse RM. Depression sum-scores don't add up: why analyzing specific depression symptoms is essential. BMC Med. 2015;13: 72-89.

104. Kozinszky Z, Töreki A, Hompoth EA, Dudas RB, Németh GL. A more rational, theory-driven approach to analysing the factor structure of the Edinburgh Postnatal Depression Scale. PSYCHIATRY Res. 2017;250: 234-43. 


\section{Appendix}

Appendix 1: Sociodemographic questionnaire

\section{Szocio-demográfiai adatlap a pszichológiai szürővizsgálathoz}

Kismama életkora:

Családi állapota:

Terhességi kor:

Gyermekek száma:

Jelenleg áll-e pszichiátriai kezelés alatt: nem igen

Betegség megnevezése:

Korábban állt-e pszichiátriai kezelés alatt: nem igen

Betegség megnevezése:

Tervezett terhesség?: igen nem

Miután válaszolt a kérdésekre, kérem töltse ki a túloldalon található EPDS kérdőívet!

Dr. Töreki Annamária

pszichológus 


\section{Appendix 2: EPDS questionnaire}

\section{Edinburgh Postnatal Depression Scale (EPDS)}

Mivel Ön várandós, vagy mostanában született gyermeke, azt szeretnénk megtudni, hogyan érzi magát. Kérem, jelölje be azokat a válaszokat, amelyek a legközelebb állnak ahhoz, ahogy Ön érezte magát az elmúlt 7 napban (és nem csak jelenleg).

$\underline{\text { Tehát az elmúlt } 7 \text { napban... }}$

1. Képes voltam nevetni és a dolgok mulatságos oldalát nézni.

Ugyanolyan gyakran, mint korábban

Talán kicsit ritkábban

Egyértelműen ritkábban

Egyáltalán nem

2. Örömmel vártam bizonyos dolgokat.

Ugyanúgy, mint régen

Talán kicsit ritkábban

Egyértelmúen ritkábban

Egyáltalán nem

3. Feleslegesen hibáztattam magam, amikor a dolgok rosszul mentek.

Többnyire igen

Elég gyakran

Nem túl gyakran

Soha

4. Minden különösebb ok nélkül szorongóvá, aggodalmassá váltam.

Soha

Kivételes esetekben

Több alkalommal

Nagyon gyakran

5. Minden különösebb ok nélkül félelem vagy pánik tört rám.

Nagyon gyakran

Több alkalommal

Kivételes esetekben

Soha

6. Összecsaptak fejem fölött a hullámok.

Igen, többnyire nem tudtam megbirkózni a dolgokkal.

Igen, néha nem tudok oly mértékben megbirkózni azokkal, mint korábban.

Nem, többnyire jól elboldogulok azokkal.

Nem, ugyanolyan jól megbirkózom azokkal, mint korábban. 
7. Olyan boldogtalan voltam, hogy problémám volt az alvással.

Többnyire igen

Több alkalommal

Csak ritkán

Soha nem fordult elő

8. Szomorúnak vagy szerencsétlennek éreztem magam.

Többnyire igen

Elég gyakran

Csak ritkán

Soha nem fordult elő

9. Annyira boldogtalannak éreztem magam, hogy sírva fakadtam.

Igen, legtöbbször

Igen, elég gyakran

Csak ritkán

Soha nem fordult elő

10. Eszembe jutott már, hogy kárt teszek magamban.

Elég gyakran

Néha

Szinte soha

Soha 
Publications providing the basis and related to the topic of the thesis

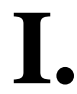




\section{Associations Between Depression Symptoms, Psychological Intervention and Perinatal Complications}

\section{Emőke Adrienn Hompoth, Zoltán Pető, Veronika Fürészné Balogh \& Annamária Töreki} Journal of Clinical Psychology in
Medical Settings

ISSN 1068-9583

J Clin Psychol Med Settings DOI 10.1007/s10880-019-09632-4

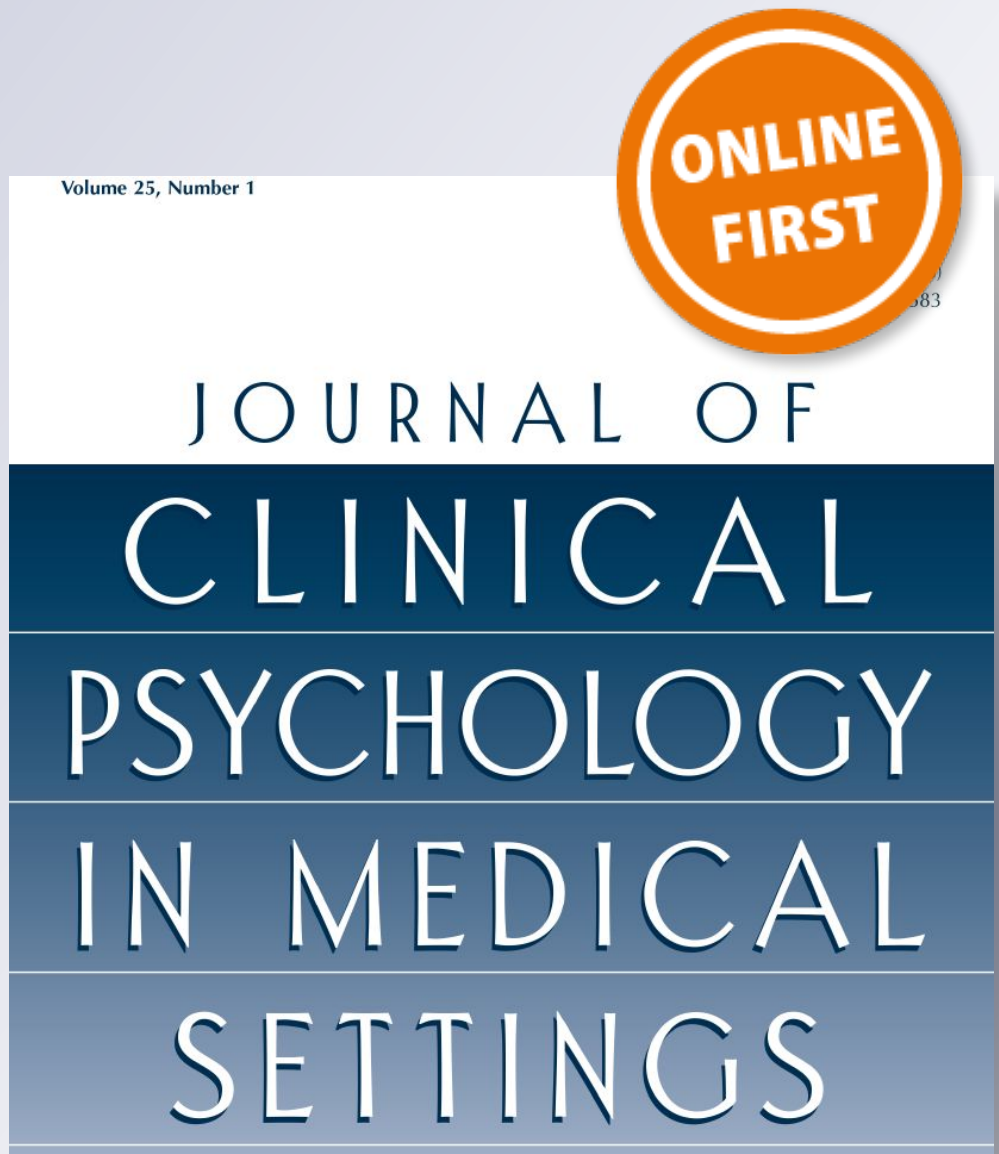

Edited by Ronald T. Brown

Springer

Springer 
Your article is published under the Creative Commons Attribution license which allows users to read, copy, distribute and make derivative works, as long as the author of the original work is cited. You may selfarchive this article on your own website, an institutional repository or funder's repository and make it publicly available immediately. 


\title{
Associations Between Depression Symptoms, Psychological Intervention and Perinatal Complications
}

\author{
Emőke Adrienn Hompoth ${ }^{1,2} \cdot$ Zoltán Petö $^{2} \cdot$ Veronika Fürészné Balogh ${ }^{3} \cdot$ Annamária Töreki $^{2}$
}

(c) The Author(s) 2019

\begin{abstract}
Antenatal and postpartum depression has been associated with maternal, child and family-unit complications. Our aim was to assess the impact of a depression screening and intervention program on perinatal complications. This study included 2042 women. They were screened on the Edinburgh Postnatal Depression Scale (EPDS), three times during pregnancy and once after childbirth. If their EPDS score was above the cut-off score, psychological intervention was offered. Significant relationships were found between depression scores and perinatal complications, such as protracted cervical dilation, protracted descent, preeclampsia, intrauterine growth restriction, low birthweight and cesarean section. Depression scores were higher in the intervention group, compared to the non-intervention group, but decreased after the consultations. The cesarean section rate was significantly lower in the consultation group. A rapid screening process can provide an adequate tool to identify women who are more likely to have such complications due to depression.
\end{abstract}

Keywords Antenatal and postpartum depression screening - Antenatal care · Postnatal care $\cdot$ Psychological intervention . Obstetric complications

\section{Introduction}

Pregnancy and the postpartum period can be very demanding and women need well-functioning cognitive skills-such as time-management skills, a well-functioning memory and decision-making skills - to be able to manage all the challenges that motherhood brings. If these cognitive functions are altered due to postpartum depression, the infant can be adversely affected; therefore, the condition of the mother is considered to be an important healthcare issue (Logsdon, Wisner, \& Pinto-Foltz, 2006).

Untreated depression was shown to be a risk factor for unfavorable pregnancy outcomes (Marcus, 2009) such as increased substance use, underutilization of antenatal

Emőke Adrienn Hompoth

hompothemoke@gmail.com

1 Department of Personality, Clinical and Health Psychology, University of Szeged, Egyetem Street 2, Szeged 6722, Hungary

2 Department of Emergency Medicine, University of Szeged, Szeged, Hungary

3 Department of Obstetrics and Gynecology, University of Szeged, Szeged, Hungary care and inadequate weight gain (Marcus \& Flynn, 2008). Depression is also associated with preterm birth (Jesse, Seaver, \& Wallace, 2003), intrauterine growth restriction (Grote, Bridge, Gavin, Melville, Iyengar, \& Katon, 2010), low birthweight (Rahman, Bunn, Lovel, \& Creed, 2007; Hompoth, Töreki, B. Fürész, \& Németh, 2017) and a higher rate of cesarean section (Chung, Lau, Yip, Chiu, \& Lee, 2001).

Known risk factors for developing depression in the antenatal phase are low self-esteem, antenatal anxiety, low social-support and negative cognitive style, but major life events can lead to depression symptoms, as well (Leigh \& Milgrom, 2008). Postpartum risk factors are antenatal depression and anxiety, childcare stress, low socialsupport, an unsatisfactory marital relationship, unplanned or unwanted pregnancy (Beck, 2001) and cesarean section (Kovácsné Török, 2009). To minimize the potentially harmful effects of the mother's depression on her infant, preventive measures and early identification and provision of treatment are very important (Beck, 2001). Effective management of the depression symptoms can be difficult, since women rarely seek treatment (Logsdon et al., 2006). This might be partly because they often think that these depression symptoms are due to pregnancy-related 
changes (O’Mahen, Flynn, Chermack, \& Marcus, 2009). In addition, women are often afraid of the social stigma associated with postpartum depression (Beck, 2001). According to Flynn, O’Mahen, Massey and Marcus (2006), when pregnant women are informed about depression symptoms by their physicians, they are more likely to seek treatment before their next antenatal follow-up. Those women who had a serious fear of childbirth and attended psychological intervention (psychoeducation and relaxation) were significantly more likely to choose vaginal birth instead of elective cesarean section (Saisto, Toivanen, Salmela-Aro, \& Halmesmäki, 2006). In Hungary, pregnant women do not have the opportunity to choose between vaginal birth and cesarean section. We wanted to investigate whether psychological intervention is connected to lower rates of cesarean section, because we found no reference to this topic in the literature.

The depression screening program in the antenatal and postpartum period in X started on April 2011 and is still fully operational. In our work, the primary aims were to assess the prevalence of depression symptoms during the antenatal and postpartum periods and to determine whether the screening tool scores are related to antenatal and obstetric complications. We also wanted to know how the psychological consultations affected depression scores and obstetric outcomes within the study group. Our hypotheses (H) were as follows:

- $\mathrm{Hl}$ women in the complication groups (specified in the statistical analysis part of this paper) will have higher depression scores compared to women in the control group

- $H 2$ the depression scores of women who had a cesarean section will be higher in the antenatal and postpartum phase compared to women who had a vaginal delivery

- $H 3$ the depression scores will be lower after the interventions compared to the before-intervention state

- $H 4$ women in the intervention group will have a lower complication rate compared to women in the non-intervention group

- H5 The cesarean section rate of women who attended the intervention during their pregnancy will be lower compared to women in the non-intervention group.

\section{Materials and Methods}

\section{Ethical Approval}

The study was approved by the Clinical Research Ethics Committee of the University of Szeged (100/2010) and was carried out according to the Declaration of Helsinki and the Oviedo Convention.

\section{Sample}

Since 2011, 4593 women took part in the depression screening program. The only exclusion criterion was lack of fluency in Hungarian. In the last 3 years, 2118 women's obstetric data were collected from our patient-record system. We excluded 26 women with twins and 50 women with a procured or spontaneous abortion or stillbirth from the study. Thus, 2042 women were included in the study sample.

\section{Screening Tool}

The Edinburgh Postnatal Depression Scale (EPDS)—created by Cox, Holden and Sagovsky (1987) and translated into the Hungarian language and validated by Töreki et al. (2013, 2014) — was used as the screening tool. This is a short, ten-item questionnaire that measures the mood status of the previous week. For each question, women can choose from four answers, which are scored from 0 to 3 points. The 10th question of which measures suicidal tendency: women have to indicate how often they think about harming themselves. We used the validated depression cut-off scores of $6 / 7$ in the antenatal period, and $7 / 8$ in the postpartum phase. This means that until 6 points in the antenatal period, and 7 points in the postpartum phase, the result was in the normal range, but above these figures depression was probable.

It is important to emphasize that the EPDS is a screening tool, not a diagnostic one. We use the terms "depression" or "depressed" only for better understanding; we do not want to imply that we diagnosed these women as having a clinical disorder.

\section{Screening Procedure and Study Design}

Perinatal nurses play a major role in the screening process, as they meet pregnant women regularly in every trimester, and during the postpartum period, as part of pregnancy care. At the first pregnancy care meeting (usually in the first trimester), the perinatal nurse explained the essence and aims of the screening, then she provided women with the written informed consent form, the demographic data sheet and, finally, the EPDS questionnaire. Women filledout the EPDS three more times, once during the second trimester, again during the third trimester, then once more during the postpartum period (between weeks 4 and 6). 
Perinatal nurses sent the questionnaires to the Department of Obstetrics and Gynecology psychologist, who registered the results into the patient-record system. As part of the screening program, psychological consultation was offered and provided, both in the antenatal and the postpartum period, to those women who scored above the cut-off value.

Because each woman in our sample filled out the EPDS questionnaire several times, our study design is Repeated Measures Within-Subject design.

\section{Intervention}

From the 2118 women whose obstetric data were collected, 188 women asked for psychological consultation as part of the screening program. From these 188, we excluded 38 women with twins and women who had a procured or spontaneous abortion or stillbirth. The remaining 150 women constituted the intervention group. The remaining 1892 women made up the non-intervention group.

During the psychological intervention sessions, two health psychologists explored the features of symptoms more deeply, including onset, changes in intensity and their impact on women's everyday lives. The level of support provided by her family, friends and surroundings was assessed, as well. The content and duration of sessions were not strictly predetermined, and the problems most bothering the individual were focused upon. The number of sessions was also adjusted to each woman's needs. The intervention style was person-to-person and each session lasted a nominal $45 \mathrm{~min}$. The main goals of the interventions were to support women in maintaining healthy function and to help them to cope with symptoms.

The methods used by the psychologist were the following: supporting and reinforcement, psychoeducation, relaxation techniques, crisis-intervention, enhancing coping skills and sense of control, reducing anxiety, hopelessness and depression symptoms, providing assistance in coping with various losses, relationship counselling and cognitive-behavioral elements. When psychiatric intervention appeared to, perhaps, be required, women were directed to a medical care specialist in the Department of Psychiatry at University of Szeged.

\section{Statistical Analysis}

We used IBM SPSS Statistics, version 22, for statistical analysis. We set the significance level to 0.05 . We created groups based on the EPDS scores, the complications, modeof-birth and attendance at the interventions.

Using the women's obstetric data, we created seven complication groups: (1) preterm birth (under 36 weeks), (2) protracted cervical dilation, (3) protracted descent, (4) preeclampsia, (5) gestational diabetes mellitus (GDM), (6) intrauterine growth restriction (IUGR) and (7) low birthweight (under $2500 \mathrm{~g}$ ). The control group was made up of women who did not have any of these complications. Mode-of-birth was divided into two groups: cesarean section (with emergency and elective cesarean section) and vaginal birth. Women who attended the interventions constituted the intervention group and everyone else was in the non-intervention group.

To enhance the power of the analyses, we supplemented the missing data of the EPDS scores: we calculated the median value of the scores of the four measuring occasions separately for the following groups: the seven complication groups and (8) women who had two or more of the above-mentioned complications and (9) women who had none of the abovementioned complications. We used this method because previous studies have found connections between depression and most of these complications; thus, calculating only one median value per measuring occasion could have distorted the results. In all, we supplemented 182 scores in the first trimester, 404 and 646 scores in the second and third trimesters, respectively, and 903 scores in the postpartum period.

We used non-parametric tests in the statistical analyses because these methods do not require a normal distribution. These tests transform the data (the EPDS scores) in their computations, and their results are mean ranks (instead of EPDS score means). The results are a little harder to interpret: they cannot be directly compared to the EPDS scores, but these methods are more reliable when the variables are not normally distributed, although higher mean ranks refer to more depression symptoms, just like higher EPDS scores.

We explored pathological rates using Frequencies analysis on depression and non-depression groups in each trimester. Friedman's test was used to analyze whether EPDS mean ranks change over time, as pregnancy proceeds and after the child is born. Mann-Whitney $U$ tests with Bonferroni Corrections were used to analyze whether EPDS mean ranks were connected to perinatal complications. A Mann-Whitney $U$ test was used to determine whether there was any connection between the EPDS mean ranks and mode-of-birth.

A Kruskal-Wallis test with pairwise comparisons was used to analyze whether there was a difference in the EPDS mean ranks between women who started the intervention in different trimesters or did not attend at all. Pearson's $\chi^{2}$ tests were used to determine whether there were any connections between intervention and perinatal complications and modeof-birth. Non-supplemented EPDS scores and a Wilcoxon Signed-Rank test were used to explore whether the EPDS mean ranks changed after the consultations compared to the before-intervention state. 


\section{Results}

\section{Sample Characteristics}

The responding women's ages were 15-44 years, and the mean age of the sample was 30.43 years $(\mathrm{SD}=4.859)$. Some 1527 women $(82.4 \%)$ were in a relationship, engaged or married; 1048 women (56.3\%) did not have any children yet and 218 women $(11.8 \%)$ had not planned their pregnancy.

The EPDS questionnaires were obtained around week $10.59,22.44$ and 34.43 during pregnancy, and week 4.81 after childbirth. According to the scores, $16.8 \%$ of the respondents were depressed in the first trimester, $12.2 \%$ and $10.5 \%$ in the second and third trimester, and $7.7 \%$ in the postpartum phase.

We analyzed the demographic characteristics of the intervention and non-intervention group, too. In the nonintervention group, the responding women's ages ranged between 15 and 44 (mean $=30.45 \mathrm{SD}=4.182)$. Some 1428 women $(83 \%)$ were in a relationship, engaged or married; 963 women $(55.8 \%)$ did not have any children yet, and 184 women (10.8\%) had not planned their pregnancy. In the intervention group, the responding women's ages ranged between 16 and 43 (mean $=30.09 \mathrm{SD}=5.454)$. Some 99 women $(74.4 \%)$ were in a relationship, engaged or married; 85 women $(63.4 \%)$ did not have any children yet, and 34 women (25.4\%) had not planned their pregnancy. As we can see, women in the intervention group were less likely to be in a relationship, more likely to be having their first child, and almost two-and-a-half times more likely to be having an unplanned pregnancy.

\section{Intervention and EPDS Scores, Participation Rate}

According to the EPDS scores, 1561 (76.44\%) women did not need intervention, but 37 of them came anyway, because they felt they needed to. In all, $481(23.56 \%)$ women were offered consultation because their EPDS scores were over the cut-off value, but only 113 (23.5\%) of them attended.

The number of sessions varied from one to twenty, the mean being $3.4(\mathrm{SD}=3.9)$. The problems that were the focus of the interventions also varied: stress, low mood, panic symptoms, anxiety and obsessive thoughts, relationship difficulties and conflicts with family, but women talked about feelings of being a bad mother, fear of birth, previous abortion or stillbirth and posttraumatic stress symptoms from previous cesarean section, too. Unplanned pregnancy and uncertainty about wanting the child were also common topics.

The Wilcoxon Signed-Rank test showed that the EPDS mean rank significantly decreased after the consultations compared to the before-intervention state, from 38.75 to 25.57, $p<.001, N=78$.

According to the Kruskal-Wallis test, there were significant differences in the EPDS mean ranks in all four measuring occasions between women who started the intervention during different trimesters, or did not attend at all (all $p<.001)$. The pairwise comparisons are presented in Fig. 1 .
Fig. 1 Adjusted pairwise comparisons of EPDS mean ranks between intervention and nonintervention groups. $* p<.05$, $* * p<.01$

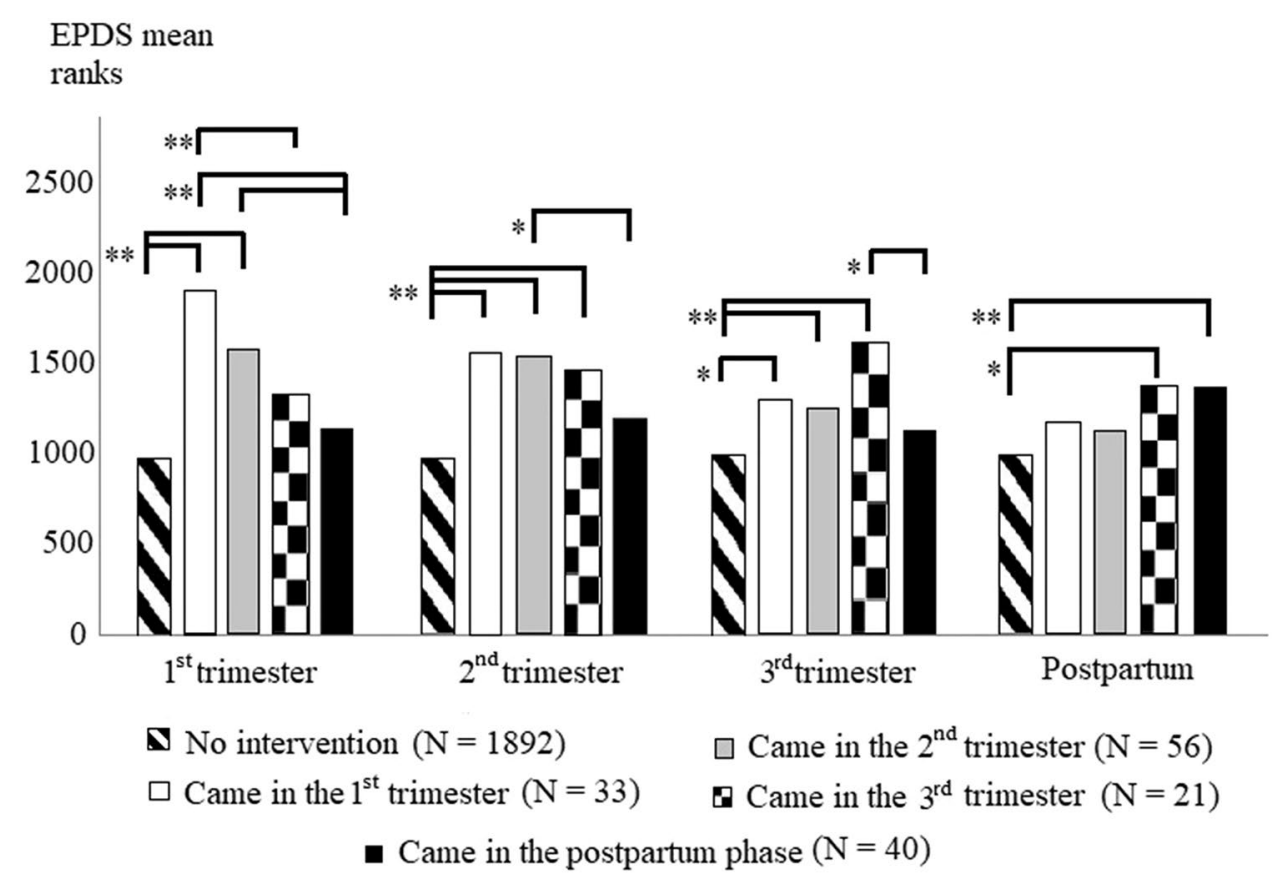


Table 1 EPDS mean ranks are connected to some of the perinatal complications

\begin{tabular}{lcccc}
\hline \multicolumn{5}{l}{ EPDS mean ranks } \\
\cline { 2 - 5 } & 1st trimester & 2nd trimester & 3rd trimester & Postpartum phase \\
\hline Protracted cervical dilation $(N=129)$ & 833.07 & 834.74 & 825.2 & 806.54 \\
No complication $(N=1523)$ & 825.94 & 825.8 & 841.79 & 1062.14 \\
$p$ & .870 & .835 & .693 & $.000^{*}$ \\
Protracted descent $(N=48)$ & 856.44 & 913.44 & 1044.55 & 1047.61 \\
No complication $(N=1523)$ & 783.78 & 781.98 & 777.85 & 777.75 \\
$p$ & .271 & $.043^{\mathrm{t}}$ & $.000^{*}$ & $.000^{*}$ \\
Preeclampsia $(N=52)$ & 817.08 & 837.52 & 698.97 & 1004.47 \\
No complication $(N=1523)$ & 787.01 & 786.31 & 791.04 & 780.61 \\
$p$ & .636 & .414 & .135 & $.000^{*}$ \\
IUGR $(N=27)$ & 797.91 & 972.20 & 942.65 & 846.83 \\
No complication $(N=1523)$ & 775.10 & 772.01 & 772.54 & 774.24 \\
$p$ & .791 & $.018^{\mathrm{t}}$ & $.042^{\mathrm{t}}$ & .366 \\
Low birthweight $(N=94)$ & 861.01 & 972.78 & 900.84 & 891.33 \\
No complication $(N=1523)$ & 805.79 & 798.89 & 803.33 & 803.92 \\
$p$ & .262 & $.000^{*}$ & $.040^{\mathrm{t}}$ & $.057^{\mathrm{t}}$ \\
\hline
\end{tabular}

The relationship is significant if $p \leq .007$ (Bonferroni correction)

*Significant

${ }^{\mathrm{t}}$ Tendency relationship

\section{Perinatal Complications and EPDS Scores}

The Mann-Whitney U tests with Bonferroni Corrections showed that EPDS mean ranks were associated with protracted cervical dilation, protracted descent, preeclampsia, IUGR and low birthweight (Table 1), but not with premature birth and GDM (all $p>.117$ ).

\section{Perinatal Complications and Intervention}

According to the Pearson's $\chi^{2}$ tests, no difference was found between the intervention and non-intervention groups in the following perinatal complications: preeclampsia, GDM, IUGR, premature birth, low birthweight, protracted cervical dilation and protracted descent (all $p>.150$ ).

\section{Mode-of-birth and EPDS scores}

The Mann-Whitney $U$ test showed a connection between the EPDS mean ranks and mode-of-birth: those women who had a cesarean section $(N=826)$ had significantly higher mean ranks (1060.92 points) in the postpartum period compared to women who had a vaginal birth (993 points, $N=1214$ ), $p=.007$. No significant connection was found during pregnancy, all $p>.184$.

\section{Mode-of-birth and intervention}

According to the Pearson's $\chi^{2}$ tests, there was a relationship between intervention and mode-of-birth: women who
Table 2 The association between intervention during pregnancy and mode of birth

\begin{tabular}{llll}
\hline & $\begin{array}{l}\text { Non-intervention } \\
\text { group during preg- } \\
\text { nancy } N\end{array}$ & $\begin{array}{l}\text { Intervention group } \\
\text { during pregnancy } \\
N\end{array}$ & $p$ \\
\hline Vaginal birth & $1121(59.31 \%)$ & $76(69.09 \%)$ & $.042^{*}$ \\
Cesarean section & $769(40.69 \%)$ & $34(30.91 \%)$ & \\
Total & $1890(100 \%)$ & $110(100 \%)$ & \\
\hline
\end{tabular}

${ }^{*} p<.05$

began the intervention during their pregnancies were significantly less likely to have a cesarean section compared to women who did not participate in the intervention (30.9\% vs. $40.69 \%), \chi^{2}(1)=4.137, p=.042$ (Table 2 ).

\section{Discussion}

Our results showed significant and tendency relationships between antenatal EPDS mean ranks and obstetric outcomes, such as protracted cervical dilation, protracted descent, IUGR, low birthweight, preeclampsia and depression scores. Not all complication groups showed higher depression scores compared to the control group; thus, our first hypothesis was partly supported. These outcomes confirm previous results (Marcus \& Flynn, 2008; Grote et al., 2010; Rahman et al., 2007; Hompoth et al., 2017; Chung et al., 2001), but this study highlighted that with a short, 
rapid-screening tool, women at risk of these outcomes can be identified and taken care of. Our second hypothesis was also partly supported, as women had higher EPDS scores after cesarean section compared to women who had a vaginal delivery, but we found no significant difference between these groups during pregnancy. In addition to significant relationships, the tendency associations are important to mention, as well, because they also indicate which connections between EPDS mean ranks and outcomes should be addressed through further investigations.

In the literature, about $6.5 \%$ of the identified depressed women asked for professional help (Goodman, 2009), but in our sample this figure was $23.5 \%$. The reason for this difference might come from the usually good mother and perinatal nurse connection, in Hungary. Women usually have a good relationship with their perinatal nurses; they trust them, and in the screening program these perinatal nurses suggested women exhibiting possible depression symptoms to seek professional help. However, it should be noted that still less than one quarter of women with high EPDS scores contacted the psychologist. This might be (as women in the intervention group often mentioned) because, in Hungary, there is still a stigma against seeking psychotherapy: most people are still afraid that others would think they are mentally challenged if they ask for psychological help. It is not helpful, either, that extreme or violent psychotic symptoms and behavior are associated with postpartum depression in the media, which makes women confuse the two conditions; consequently, they refuse to ask for help as they do not want to be associated with such aberrant behavior. Public education explaining the differences between the two conditions might help to reverse this negative tendency (Beck, 2001).

Our results showed that the EPDS mean ranks were higher in the intervention groups compared to the nonintervention group. This may be due to the phenomenon that most women in the non-intervention group (80.55\%) did not show such pathological depression symptoms during this period, which implies they were better at coping with the situation and its difficulties. It seems, as their pregnancy progressed, they could adapt to the changes and, perhaps, their insecurity decreased. In almost all intervention groups, the EPDS ranks were highest in the trimester when women started the intervention. This might imply that all the women could cope with some of their problems along the way, but reached a point where they felt overwhelmed, and then asked for help. This, too, looks promising, because not every problem needs professional support, as we saw in the non-intervention group, but when there was a need, some women could and did reach out for help. After women attended the interventions, their EPDS ranks tended to decrease in all the subsequent measuring occasions. In addition, the afterintervention EPDS scores were significantly lower compared to the before-intervention scores, which also supports our third hypothesis. According to Milgrom, Schembri, Ericksen, Ross and Gemmill (2011), those women who attended antenatal psychological interventions had lower depression scores in the postpartum phase compared to women who did not attend. In our sample this was not observable, although the mean EPDS ranks of those groups starting the intervention in the first or second trimester did not differ significantly from the EPDS ranks of the non-intervention group. This implies that antenatal psychological interventions started sooner rather than later could help in the prevention of postpartum depression.

Our results showed that women in the intervention group were less likely to give birth to their baby by cesarean section compared to the non-intervention group; thus, our fifth hypothesis was supported. According to Laursen, Johansen and Hedegaard (2009), women with fear of the actual delivery were more likely to have a protracted labor and an emergency cesarean section. During the interventions, some women talked about their fear of childbirth, which became the focus for some of the later consultations. It seems possible that psychoeducational consultations might lead to less-stressful deliveries with fewer cesarean sections, but further investigation is needed to determine the consultations' contribution.

No significant differences were found in other obstetric outcomes, such as IUGR and low birthweight, between the intervention and non-intervention groups; thus, our fourth hypothesis was not supported. However, this result might be promising, because EPDS ranks were higher in all the intervention groups (in some cases significantly higher) compared to the non-intervention group and, as we presented earlier, some of the complications were associated with higher EPDS ranks. The fact that the statistical analysis revealed no associations with the complications (although those women had higher EPDS ranks) might mean that psychological intervention can provide a kind of protective factor against these negative outcomes, but to confirm this hypothesis further studies are needed.

\section{Limitations}

Patient mobility limited the study, since not all women filledout the EPDS all four times since, sometimes, women moved away or had only moved to Szeged after the first trimester. Sometimes, perinatal nurses forgot to give the questionnaire to the mothers, as well. Another limitation was the sample size: we believe that the overall sample was big enough; however, the sample sizes of the adverse obstetric outcome groups were quite low. Higher intervention participation would, most probably, be more appropriate and make our results more reliable. 


\section{Conclusions}

In conclusion, our results support previous findings that depression symptoms may contribute to adverse pregnancy and obstetric outcomes. However, this effect can be reduced with psychological intervention; therefore, it is important to identify and to treat those women who are at risk of developing depression symptoms. Our research shows that the EPDS screening tool might play an important role in this identification of need.

Acknowledgements Open access funding provided by University of Szeged (SZTE). We would like to thank all those perinatal nurses who obtained the questionnaire from the participating women. Without their essential help, this study could not exist.

Funding There was no financial assistance with the project.

\section{Compliance with Ethical Standards}

Conflict of interest Emőke Adrienn Hompoth, Zoltán Pető, Veronika Fưrészné Balogh, and Annamária Töreki declare that they have no conflict of interest.

Human and Animal Rights All procedures performed in studies involving human participants were in accordance with the ethical standards of the Clinical Research Ethics Committee of the University of Szeged (100/2010) and with the 1964 Helsinki declaration and its later amendments or comparable ethical standards. This article does not contain any studies with animals performed by the authors.

Informed Consent Informed consent was obtained from all individual participants included in the study.

Open Access This article is distributed under the terms of the Creative Commons Attribution 4.0 International License (http://creativeco mmons.org/licenses/by/4.0/), which permits unrestricted use, distribution, and reproduction in any medium, provided you give appropriate credit to the original author(s) and the source, provide a link to the Creative Commons license, and indicate if changes were made.

\section{References}

Beck, C. T. (2001). Predictors of postpartum depression: An update. Nursing Research, 50, 275-285.

Chung, T. K., Lau, T. K., Yip, A. S., Chiu, H. F., \& Lee, D. T. (2001). Antepartum depressive symptomatology is associated with adverse obstetric and neonatal outcomes. Psychosomatic Medicine, 63, 830-834.

Cox, J. L., Holden, J. M., \& Sagovsky, R. (1987). Detection of postnatal depression. Development of the 10-item Edinburgh Postnatal Depression Scale. British Journal of Psychiatry, 150, 782-786.

Flynn, H. A., O'Mahen, H. A., Massey, L., \& Marcus, S. (2006). The impact of a brief obstetrics clinic-based intervention on treatment use for perinatal depression. Journal of Women's Health, $15,1195-1204$.
Goodman, J. H. (2009). Women's attitudes, preferences, and perceived barriers to treatment for perinatal depression. Birth, 36, 60-69.

Grote, N. K., Bridge, J. A., Gavin, A. R., Melville, J. L., Iyengar, S., \& Katon, W. J. (2010). A meta-analysis of depression during pregnancy and the risk of preterm birth, low birth weight, and intrauterine growth restriction. Archives of General Psychiatry, 67, 1012-1024.

Hompoth, E. A., Töreki, A., Baloghné Fûrész, V., \& Németh, G. (2017). A hangulati állapot alakulásának kockázati tényezői a perinatalis időszakban [The risk factors of mood changing during the perinatal period]. Orvosi Hetilap, 158, 139-146.

Jesse, D. E., Seaver, W., \& Wallace, D. C. (2003). Maternal psychosocial risks predict preterm birth in a group of women from Appalachia. Midwifery, 19, 191-202.

Kovácsné, T. Z. (2009). Psychiatric disorders associated to childbirth, especially postpartum depression. PhD thesis. [Szüléshez társuló pszichiátriai zavarok, különös tekintettel a gyermekágyi lehangoltság kérdéskörére. PhD tézis.]. University of Debrecen.

Laursen, M., Johansen, C., \& Hedegaard, M. (2009). Fear of childbirth and risk for birth complications in nulliparous women in the Danish National Birth Cohort. British Journal of Obstetrics and Gynaecology, 116, 1350-1355.

Leigh, B., \& Milgrom, J. (2008). Risk factors for antenatal depression, postnatal depression and parenting stress. BMC Psychiatry, 8, 24.

Logsdon, M. C., Wisner, K. L., \& Pinto-Foltz, M. D. (2006). The impact of postpartum depression on mothering. Journal of Obstetric, Gynecologic, and Neonatal Nursing, 35, 652-658.

Marcus, S. M. (2009). Depression during pregnancy: Rates, risks and consequences. The Canadian Journal of Clinical Pharmacology, $16,15-22$.

Marcus, S. M., \& Flynn, H. A. (2008). Depression, antidepressant medication and functioning outcomes among pregnant women. International Journal of Gynecology \& Obstetrics, 100, 248-251.

Milgrom, J., Schembri, C., Ericksen, J., Ross, J., \& Gemmill, A. W. (2011). Towards parenthood: An antenatal intervention to reduce depression, anxiety and parenting difficulties. Journal of Affective Disorders, 130, 385-394.

O’Mahen, H. A., Flynn, H. A., Chermack, S., \& Marcus, S. (2009). Illness perceptions associated with perinatal depression treatment use. Archives of Women's Mental Health, 12, 447-450.

Rahman, A., Bunn, J., Lovel, H., \& Creed, F. (2007). Association between antenatal depression and low birthweight in a developing country. Acta Psychiatrica Scandinavica, 115, 481-486.

Saisto, T., Toivanen, R., Salmela-Aro, K., \& Halmesmäki, E. (2006). Therapeutic group psychoeducation and relaxation in treating fear of childbirth. Acta Obstetrica et Gynecologica Scandinavica, 85, 1315-1319.

Töreki, A., Andó, B., Dudás, R. B., Dweik, D., Janka, Z., Kozinszky, Z., \& Keresztúri, A. (2014). Validation of the Edinburgh Postnatal Depression Scale as a screening tool for postpartum depression in a clinical sample in Hungary. Midwifery, 30, 911-918.

Töreki, A., Andó, B., Keresztúri, A., Sikovanyec, J., Dudas, R. B., Janka, Z., ... Pál, A. (2013). The Edinburgh Postnatal Depression Scale: Translation and antepartum validation for a Hungarian sample. Midwifery, 29, 308-315.

Publisher's Note Springer Nature remains neutral with regard to jurisdictional claims in published maps and institutional affiliations. 
II. 


\title{
Depressziószürés a várandósgondozásban
}

\author{
Eredmények Békéscsaba körzetéböl
}

\author{
Hompoth Emőke Adrienn ${ }^{1}$ - Gálosi Natália ${ }^{2}$ \\ Becsei László dr. $^{3}$ - Töreki Annamária dr. ${ }^{1}$
}

\author{
${ }^{1}$ Szegedi Tudományegyetem, Általános Orvostudományi Kar, Szentágothai Klinikai Központ, \\ Sürgősségi Betegellátó Önálló Osztály, Szeged \\ ${ }^{2}$ Békés Megyei Büntetés-végrehajtási Intézet, Gyula \\ ${ }^{3}$ Békés Megyei Központi Kórház, Békéscsaba
}

\begin{abstract}
Bevezetés: Bár a várandósság általában vágyott állapot, mégis megvannak a maga nehézségei, melyek megterhelők lehetnek, így lehangoltság, depresszió alakulhat ki. Ennek prevalenciája a nemzetközi szakirodalomban 6,58-26,7\%, magyar mintákon 6,5-17,9\%.

Célkitüzés: A 2014-ben Békéscsabán elindult, a várandósság alatti és a szülés utáni depressziószúrés adatainak elemzése: a patológiás arány felmérése, illetve a demográfiai tényezők és a depressziós tünetek mértéke közötti összefüggések vizsgálata.

Módszer: 2019 augusztusáig 1708 nő vett részt a szúrésben, melynek lebonyolítását a védőnők végzik: ook magyarázzák el a program lényegét, töltetik ki és értékelik az Edinburgh Postnatal Depression Scale kérdőívet mindhárom trimeszterben, valamint a szülés után is egyszer-egyszer. Szükség esetén pedig javasolják a kitöltőnek, hogy vegye igénybe a szűrốprogram részeként a pszichológiai intervenciót.

Eredmények: A négy mérési alkalom során a határérték feletti kérdőívek prevalenciája a következő: 15,31\%, 14,29\%, $11,87 \%, 12,68 \%$. A teljes minta 18,27\%-a mutatott legalább egyszer emelkedett depressziós tüneteket. A négy mérési alkalom depresszió-pontértékei szignifikánsan, közepes erősséggel korreláltak egymással. Emellett mind a négy mérési alkalommal szignifikánsan magasabb volt a depressziószintje azoknak a nóknek, akik nem tervezték várandósságukat. Az első trimeszterben volt szignifikáns összefüggés a korral és a családi állapottal: a 21 év alatti, illetve az egyedülálló nők szignifikánsan magasabb depressziószintet mutatnak a 21 évnél idősebb, illetve a kapcsolatban/házasságban élö társaikhoz képest. A paritással tendenciaszerú kapcsolat volt a második trimeszterben: a multiparáknak tendenciaszerúen magasabb volt a pontértékük.

Következtetés: A magas prevalencia, valamint a depressziószint állandósága megerősíti a szürés és a pszichológiai intervenció fontosságát, hiszen korábban találtak összefüggést a depresszió és bizonyos szülészeti komplikációk között. Egyes demográfiai faktorok mint rizikótényezók jelezhetik, hogy ki a veszélyeztetettebb.
\end{abstract}

Orv Hetil. 2020; 161(10): 374-381.

Kulcsszavak: depressziószürés, várandósság, postpartum, védőnő

\section{Depression screening in the pregnancy care}

\section{Results from the area of Békéscsaba}

Introduction: Pregnancy is usually desired, yet it has its own difficulties that can be overwhelming, thus depression might occur. The prevalence of this is $6.58-26.7 \%$ in the international literature and $6.5-17.9 \%$ in Hungarian studies. Aim: The aim was to analyze the data of the perinatal depression screening program of Békéscsaba which started in 2014. We wanted to study the pathological rate and the connection between demographic data and depression symptoms.

Method: Until august 2019, 1708 women took part in the program. The screening is done by perinatal nurses: they explain the aims and hand over the Edinburgh Postnatal Depression Scale three times during pregnancy and once postpartum. They also suggest women in need to attend the psychological intervention as part of the screening. 
Results: The prevalence of the pathological questionnaires were $15.31 \%, 14.29 \%, 11.87 \%$, and $12.68 \%$ at the four measuring occasions. In the whole sample, $18.27 \%$ of women had pathological score at least once. The depression scores of the four measurements correlated significantly with each other. Women who did not plan their pregnancies had higher level of depression in all four measurements. In the first trimester, women who were under 21 years old and/or were single had higher depression scores. In the second trimester, multipara women tended to have higher scores.

Conclusion: The high prevalence and the constant level of depression emphasize the importance of the screening and psychological intervention, as previous studies found connection between depression and some perinatal complications. Some demographic factors can indicate more vulnerable women.

Keywords: depression screening, pregnancy, postpartum phase, perinatal nurse

Hompoth EA, Gálosi N, Becsei L, Töreki A. [Depression screening in the pregnancy care. Results from the area of Békéscsaba]. Orv Hetil. 2020; 161(10): 374-381.

(Beérkezett: 2019. október 13.; elfogadva: 2019. november 10.)

\section{Rövidítések}

EMMI $=$ Emberi Erőforrások Minisztériuma EPDS $=($ Edin burgh Postnatal Depression Scale) Edinburghi Postnatalis Depresszió Skála

A várandósság általában vágyott állapot, melyhez a hétköznapi gondolkodásban többnyire pozitív jelzók, elképzelések társulnak. Valójában ennek az időszaknak is megvannak a maga nehézségei, hiszen a várandósok új kihívások előtt állnak: alkalmazkodniuk kell a hormonális és egyéb fizikai változásokhoz, a formálódó új szerepekhez, az átalakult környezethez stb. Ez a folyamat időnként megterhelő lehet, esetenként pszichés tünetek kialakulásának kedvez. Ilyen például a lehangoltság és a depresszió.

Nemzetközi adatokat vizsgálva Okagbue és mtsai [1] áttekintő tanulmánya szerint a depresszió prevalenciája az antepartum időszakban 15,05\% egy 28248 fös mintán. Trimeszterenként lebontva az arányok a következőképp alakultak: 10,35\% az első trimeszterben, 6,58\% a másodikban, majd a legmagasabb a harmadikban, 26,7\%kal. Shorey és mtsai [2] a szülés utáni időszakot vizsgálták: eredményeik szerint a 3. hónapig a nók 14\%-a mutatott magasabb depressziós értéket, összesítve Európában pedig a nók 8\%-a. Magyarországon még nem történt átfogó felmérés a szülés előtti és utáni időszak depresszív tüneteit illetően, csupán egy-egy régióról született korábbi tanulmány. Egy szombathelyi kutatásban a vizsgált 307 nő 17,9\%-a küzdött magasabb depressziószinttel az első trimeszterben [3]. Békéscsabán 2014-ben egy 307 fós várandós- és postpartum minta 384 kitöltött kérdőívének 11,2\%-a mutatott emelkedett depresszióértéket [4]. Szegeden 2014-ben a 2252 fős minta 4669 kitöltött kérdőívének (ebből 499 postpartum) 8,9\%-a [4], míg 2017-ben a 3849 (közülük 747, postpartum időszakban lévő) nő által kitöltött kérdőívek 8,5\%-a mutatott magasabb depresszióértéket, ezen belül is az első trimeszter- ben $10,8 \%$, a második és harmadik trimeszterben $6,9 \%$ és $6,5 \%$, a postpartum időszakban pedig 7,8\% [5].

Korábbi tanulmányok is foglalkoztak azzal, hogy felderítsék a várandóssághoz kapcsolódó depresszió rizikóés protektív faktorait. Két nagy áttekintő tanulmány is úgy találta, hogy összefüggés van a várandósság alatti megemelkedett depressziószint és a nem tervezett várandósság, az alacsony iskolázottság, illetve jövedelem, a megterhelő életesemények, emellett az egyedülálló családi állapot, de még inkább a nem támogató partnerkapcsolat között. Ugyanakkor inkonzisztensek az eredmények a kor, a paritás, a dohányzás, az alkohol- és szerhasználat, valamint a foglalkoztatottság esetén [6, 7]. A szegedi kutatásban szintén összefüggött a várandósság alatti és szülés utáni depresszióval a nem tervezett várandósság, emellett rizikófaktornak tûnt a 26 év alatti és 34 év feletti életkor, a multiparitás, illetve a második trimeszterben az egyedülálló családi állapot [5]. Szombathelyen pedig az élettársi kapcsolatban élóknek volt magasabb a depressziópontszámuk a házasságban élőkhöz képest, emellett a munkanélküli státusz, illetve az életkor, a szocioökonómiai státusz és az iskolázottság alacsony szintje a magasabb depresszióval függött össze [3]. A postpartum depressziónak pedig jelentős rizikófaktora az antepartum depresszió $[5,8]$.

A várandóssághoz kapcsolható depresszió következményeinek vizsgálatára Plant és mtsai [9] 103 nőt és azok gyermekeit követték 26 éven keresztül. Eredményeik szerint a várandósságuk alatt depresszióval diagnosztizált nők 71,1\%-a a gyermeke gyerekkora alatt is depresszióval küzdött, illetve gyakoribb volt a gyermekkel szembeni nem megfelelő bánásmód. Emellett azok a gyerekek, akiknek anyját a várandósság alatt depresszióval diagnosztizálták, 3,4-szer nagyobb eséllyel kaptak maguk is depressziódiagnózist felnőttkorukban. A várandósság alatti depresszió továbbá olyan szülési komplikációkkal is összefüggést mutathat, mint az elhúzódó kitolás vagy az alacsony születési súly [10], melyeknek 
további negatív következményei lehetnek az utód életében.

A jelen kutatás célja a békéscsabai depressziószűrésben részt vevő nők adatain vizsgálni, hogy van-e összefüggés a demográfiai tényezők (a várandósság tervezettsége, életkor, családi állapot, paritás) és a depressziós tünetek mértéke között. Emellett célunk volt felmérni a patológiás arányt, valamint azt, hogy a depresszió mértéke hogyan változik a várandósság alatti és a szülés utáni hetekben.

\section{Módszer}

\section{A minta}

2011-ben Szegeden bevezetésre került a perinatalis depresszió szűrő́program a 100/2010. számú etikai engedély alapján, majd 2014-ben Békéscsabán a Békés Megyei Központi Kórházban mint a Szegedi Tudományegyetem oktatóintézményében is elindult a szûrés, mivel a várandósgondozás részévé vált az Emberi Erőforrások Minisztériuma szakmai irányelvének a prae-, peri- és postnatalis mentális zavarok kezeléséról szóló rendeletéhez [11] igazodva. A szúrés célja az volt, hogy a várandósság alatt vagy a szülés után nehézségekkel küzdő nők megfelelő pszichológiai segítséget kaphassanak, mellyel erősíteni lehet az új élethelyzethez való adaptációt, a nő megküzdési kapacitását. A depressziószúrésben a részvétel önkéntes, a várandósok és postpartum nők dönthetnek úgy, hogy nem töltik ki a kérdöívet.

A jelen kutatásban a békéscsabai perinatalis depresszió szürőprogramban részt vett nők adatait elemeztük. A kutatásból nem zártuk ki azokat a nőket, akik korábban valamilyen mentális problémával küzdöttek, egyrészt azért, mert átfogó képet szerettünk volna kapni, másrészt pedig mert Shorey és mtsai [2] áttekintő tanulmánya szerint nincs jelentős különbség a szülés utáni depresszió prevalenciájában a két csoport között.

1. táblázat | Demográfiai adatok

\begin{tabular}{|c|c|c|}
\hline \multirow[t]{2}{*}{ Életkor } & Átlag $(\mathrm{n}=1652)$ & Szórás \\
\hline & 30,89 & 5,319 \\
\hline \multirow[t]{3}{*}{ Családi állapot } & Egyedülálló/elvált & $\begin{array}{l}\text { Kapcsolatban/ } \\
\text { élettársi kapcsolat- } \\
\text { ban/házasságban él }\end{array}$ \\
\hline & 264 & 1374 \\
\hline & $16,12 \%$ & $83,88 \%$ \\
\hline \multirow[t]{3}{*}{ Paritás } & Primipara & Multipara \\
\hline & 884 & 762 \\
\hline & $53,71 \%$ & $46,29 \%$ \\
\hline \multirow{3}{*}{$\begin{array}{l}\text { A várandósság } \\
\text { tervezettsége }\end{array}$} & Nem tervezte & Tervezte \\
\hline & 157 & 1492 \\
\hline & $9,52 \%$ & $90,48 \%$ \\
\hline
\end{tabular}

Vizsgálatunkban annak az 1708 nőnek az adatait elemeztük, akik 2014. február és 2019. augusztus között vettek részt a szúrésben. A válaszadók átlagéletkora 30,89 év volt $(S D=5,319) ; 264$ nő volt egyedülálló vagy elvált $(16,12 \%), 884$ nő az első gyermekét várta $(53,71 \%)$, illetve 157 személy $(9,52 \%)$ nem tervezte a várandósságát (1. táblázat).

\section{Eszközök, a szürés folyamata}

A szürés során az Edinburgh Postnatal Depression Scale (EPDS) kérdőívet [12] használtuk, melynek magyar validálását várandós- és postpartum mintán Töreki és mtsai végezték [13, 14] (Melléklet). A kérdőív rövid, gyorsan kitölthető és értékelhető: tíz kérdésből áll, melyek az előző hét hangulati állapotát (lehangoltság, szorongás stb.) mérik fel, a tizedik kérdés pedig a szuicid gondolatok előfordulásának gyakoriságára kérdez rá. A kérdésekre négy válasz közül választhatnak a kitöltők, ezek értékelése 0 és 3 pont közötti lehet. Az összpontszám 0-tól 30-ig terjed. A várandósság során 6 pont felett [13], míg a szülés után 7 pont felett valószínűsíthető a minor depresszió [14].

A tájékoztató és beleegyező nyilatkozatot, a demográfiai adatlapot, valamint a kérdő́ivet a védőnők adják át kitöltésre a szűrésben részt vevő várandósoknak az első találkozásukkor. Ezt követően, a további találkozások alkalmával, ideális esetben még háromszor kerül sor a kérdőívek kitöltésére: mindhárom trimeszterben egyszeregyszer, illetve a szülés után $4-6$ héttel. Ha a kitöltő nő ponthatár feletti értéket ér el, vagy a szuicid gondolatokat felmérő kérdésnél jelzi, hogy legalább néha előfordulnak nála, akkor a védőnő javasolja, hogy keresse fel a szưrésben részt vevő pszichológust. A kitöltött kérdőíveket szintén hozzá juttatják el a védőnők, a pszichológus pedig rögzíti az adatokat a betegnyilvántartási rendszerben. Ezáltal a városban az EMMI-rendeletnek [11] megfelelően a várandósgondozás részévé vált a szűrés.

\section{Statisztika}

Az adatok elemzéséhez az SPSS Statistics program 22. verzióját (IBM Corporation, Armonk, NY, Amerikai Egyesült Államok) használtuk. Nemparaméteres próbákat alkalmaztunk, mivel az adatok nem normál eloszlásúak, illetve mivel az összehasonlítandó csoportok létszáma jelentősen különbözik egymástól. Frekvenciaanalízissel vizsgáltuk a kitöltési, valamint a patológiás arányt. Mann-Whitney-féle U-próbát végeztünk az EPDSpontszám folyamatos változón a családi állapot (egyedülálló/elvált versus kapcsolatban/élettársi kapcsolatban él/házas), a gyermekszám (még nincs gyermeke versus már van gyermeke), a tervezettség (tervezte versus nem tervezte) csoportosító változókkal. Kruskal-Wallis-próbával vizsgáltuk az EPDS folyamatos változó és a kor (kevesebb, mint 21 éves; $21-25$ éves; 26-30 éves; 31-35 éves; több, mint 35 éves) csoportosító változó közötti 


\section{Melléklet}

\section{Edinburgh Postnatal Depression Scale (EPDS)}

Mivel Ön várandós, vagy mostanában született gyermeke, azt szeretnénk megtudni, hogyan érzi magát. Kérem, jelölje be azokat a válaszokat, amelyek a legközelebb állnak ahhoz, ahogy Ön érezte magát az elmúlt 7 napban (és nem csak jelenleg).

Tehát az elmúlt 7 napban...

1. Képes voltam nevetni és a dolgok mulatságos oldalát nézni.

Ugyanolyan gyakran, mint korábban

Talán kicsit ritkábban

Egyértelmúen ritkábban

Egyáltalán nem

2. Örömmel vártam bizonyos dolgokat.

Ugyanúgy, mint régen

Talán kicsit ritkábban

Egyértelmúen ritkábban

Egyáltalán nem

3. Feleslegesen hibáztattam magam, amikor a dolgok rosszul mentek.

Többnyire igen

Elég gyakran

Nem túl gyakran

Soha

4. Minden különösebb ok nélkül szorongóvá, aggodalmassá váltam.

Soha

Kivételes esetekben

Több alkalommal

Nagyon gyakran
5. Minden különösebb ok nélkül félelem vagy pánik tört rám.

Nagyon gyakran

Több alkalommal

Kivételes esetekben

Soha

6. Összecsaptak fejem fölött a hullámok.

Igen, többnyire nem tudtam megbirkózni a dolgokkal Igen, néha nem tudok oly mértékben megbirkózni azokkal, mint korábban

Nem, többnyire jól elboldogulok azokkal

Nem, ugyanolyan jól megbirkózom azokkal, mint korábban

7. Olyan boldogtalan voltam, hogy problémám volt az alvással.

Többnyire igen

Több alkalommal

Csak ritkán

Soha nem fordult eló

8. Szomorúnak vagy szerencsétlennek éreztem magam. Többnyire igen

Elég gyakran

Csak ritkán

Soha nem fordult eló

9. Annyira boldogtalannak éreztem magam, hogy sírva fakadtam.

Igen, a legtöbbször

Igen, elég gyakran

Csak ritkán

Soha nem fordult eló

10. Eszembe jutott már, hogy kárt teszek magamban. Elég gyakran

Néha

Szinte soha

Soha összefüggést, illetve Spearman-féle korrelációval vizsgáltuk, hogy van-e összefüggés a különböző mérési alkalmak EPDS-pontszámai között.

\section{Eredmények}

Az eredmények alapján a békéscsabai mintán az első trimeszterben 1319-en vettek részt a szürésben, a második trimeszterben 595-en, a harmadik trimeszterben 396an, szülés után pedig 205-en. Az ő adataik alapján az első trimeszterben 15,31\% kapott határérték feletti pontot az EPDS skálán, a második trimeszterben 14,29\%, a harmadik trimeszterben $11,87 \%$, szülés után pedig 12,68\% (1. ábra). Összesen tehát a kitöltött 2515 kérdőívből 360 esetben volt mérhető patológiás érték, ez az összes kérdőív 14,31\%-a. Több nő esetén több mérési alkalom- mal is patológiás volt az EPDS értéke; az 1708 főből 312 nő esetében volt a négy mérési alkalom során legalább egyszer patológiás az érték, ez a minta 18,27\%-a. Ennyien küzdöttek tehát legalább egyszer emelkedett depressziós tünetekkel a várandósság alatt és/vagy a szülés után.

A Spearman-féle korrelációs vizsgálat eredményei szerint mind a négy mérési alkalom pontszámai pozitívan, szignifikánsan, közepes erősséggel függtek össze egymással $(0,44 \mathrm{l}<\mathrm{r}<0,648, \mathrm{p}<0,001)$ (2. táblázat). Ezek alapján a depresszió szintje nagyjából állandó: akinek magasabb az egyik mérési alkalom során, annak valószínúleg máskor is magasabb, és fordítva.

A Kruskal-Wallis-teszt eredménye szerint a békéscsabai mintában az első és a második trimeszterben szignifikánsan eltérnek egymástól a korcsoportok $(\mathrm{p}<0,032)$, a 


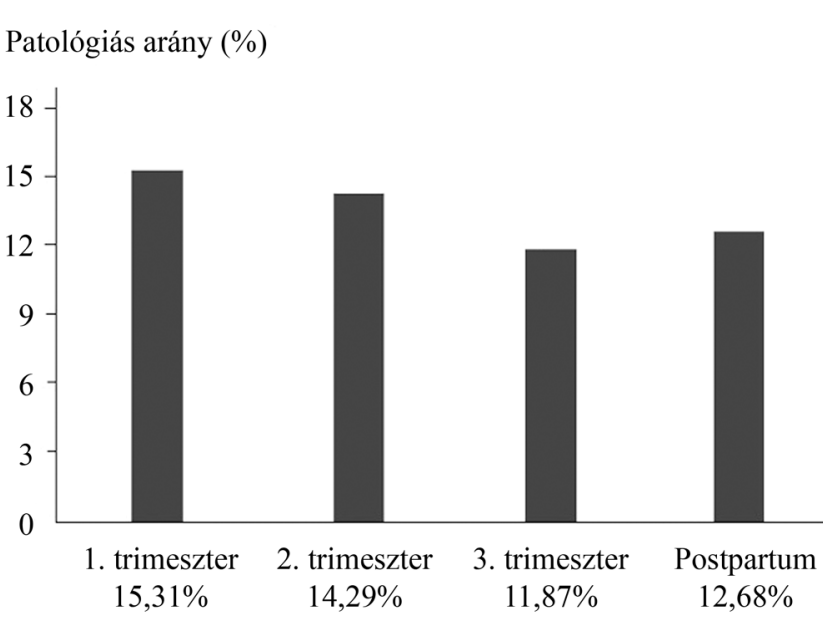

1. ábra | A depressziós tünetekkel küzdő nók aránya a mintában

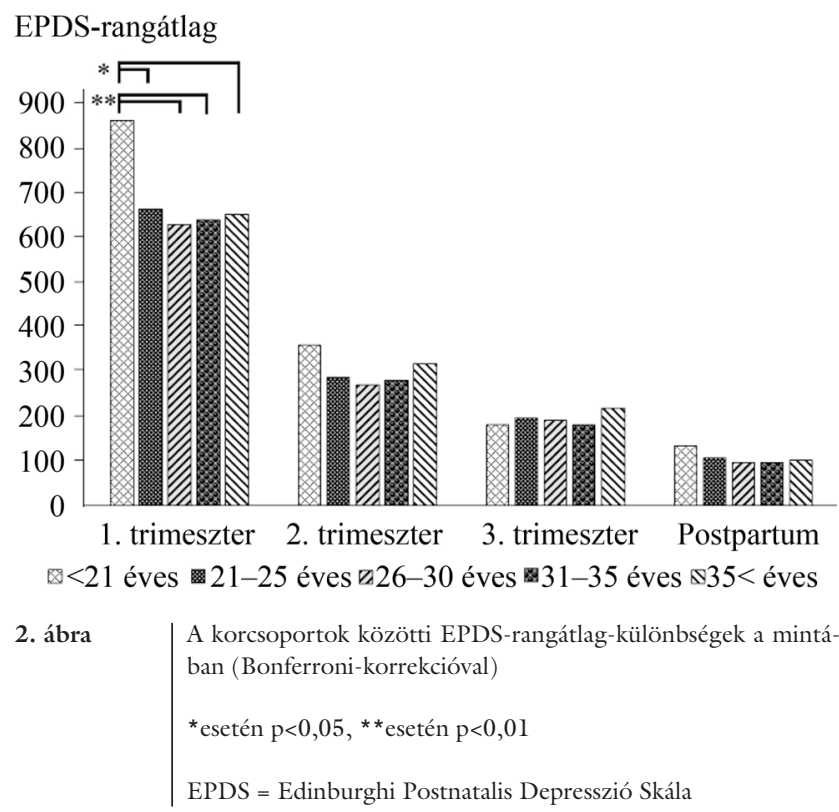

harmadik trimeszterben lévő és a szülés utáni korcsoportok viszont nem $(p>0,212)$. Korcsoportonként páros összehasonlítást végeztünk Bonferroni-korrekcióval, mely szerint csak az első trimeszterben volt szignifikáns eltérés a csoportok között: a 21 év alatti nőknek volt szignifikánsan magasabb EPDS-rangátlaguk a többi négy csoporthoz képest (2. ábra).

Mann-Whitney-féle U-teszttel vizsgáltuk, hogy van-e összefüggés a paritás és az EPDS-pontok között. Az eredmények alapján a mintán nem volt szignifikáns öszszefüggés, csupán tendenciaszerû a második trimeszterben: azoknak a nőknek, akiknek már van gyermekük, tendenciaszerúen nagyobb volt az EPDS-rangátlaguk $(299,59$ versus $276,76, \mathrm{p}=0,098)$.

A Mann-Whitney-féle U-teszt szerint a mintában a családi állapottal csak az első trimeszterben van összefüggés: az egyedülálló nőknek volt magasabb az EPDSrangátlaguk $(694,38$ versus $632,67, \mathrm{p}=0,031)$.

\begin{tabular}{lccccc} 
2. táblázat & \multicolumn{5}{l}{ Együttjárás a mérési alkalmak EPDS-pontszámai között } \\
\hline Békéscsaba & & $\begin{array}{c}1 . \\
\text { trimeszter }\end{array}$ & $\begin{array}{c}2 . \\
\text { trimeszter }\end{array}$ & $\begin{array}{c}3 . \\
\text { trimeszter }\end{array}$ & Postpartum \\
\hline 1. trimeszter & $\mathrm{r}$ & 1 & 0,573 & 0,538 & 0,442 \\
& $\mathrm{p}$ & & $<0,001$ & $<0,001$ & $<0,001$ \\
& $\mathrm{n}$ & & 354 & 223 & 114 \\
\hline 2. trimeszter & $\mathrm{r}$ & 0,573 & 1 & 0,647 & 0,603 \\
& $\mathrm{p}$ & $<0,001$ & & $<0,001$ & $<0,001$ \\
& $\mathrm{n}$ & 354 & & 190 & 85 \\
\hline 3. trimeszter & $\mathrm{r}$ & 0,538 & 0,647 & 1 & 0,507 \\
& $\mathrm{p}$ & $<0,001$ & $<0,001$ & & $<0,001$ \\
& $\mathrm{n}$ & 223 & 190 & & 71 \\
\hline Postpartum & $\mathrm{r}$ & 0,442 & 0,603 & 0,507 & 1 \\
& $\mathrm{p}$ & $<0,001$ & $<0,001$ & $<0,001$ & \\
& $\mathrm{n}$ & 114 & 85 & 71 &
\end{tabular}

EPDS = Edinburghi Postnatalis Depresszió Skála

\begin{tabular}{l|l} 
3. táblázat & $\begin{array}{l}\text { Az EPDS-rangátlagok és a várandósság tervezettségének össze- } \\
\text { függése }\end{array}$
\end{tabular}

\begin{tabular}{lcccc}
\hline Békéscsaba & \multicolumn{4}{c}{ EPDS-rangátlag } \\
\cline { 2 - 5 } & $\begin{array}{c}1 . \\
\text { trimeszter }\end{array}$ & $\begin{array}{c}2 . \\
\text { trimeszter }\end{array}$ & $\begin{array}{c}3 . \\
\text { trimeszter }\end{array}$ & Postpartum \\
\hline $\begin{array}{l}\text { Nem tervezett } \\
(\mathrm{n})\end{array}$ & 780,65 & 362,08 & 229,76 & 135,00 \\
$(112)$ & $(62)$ & $(38)$ & $(13)$ \\
\hline Tervezett & 633,21 & 279,05 & 190,11 & 97,01 \\
$(\mathrm{n})$ & $(1179)$ & $(513)$ & $(349)$ & $(185)$ \\
\hline $\mathrm{p}$ & $<0,001$ & $<0,001$ & 0,036 & 0,020 \\
\hline
\end{tabular}

EPDS = Edinburghi Postnatalis Depresszió Skála

A tervezettséggel a Mann-Whitney-féle U-teszt alapján mindegyik mérési alkalom szignifikánsan összefüggött az EPDS-rangátlagokkal (minden $\mathrm{p}<0,037$ ). Mindegyik esetben azoknak a nőknek volt magasabb az EPDS-rangátlaguk, akik nem tervezték várandósságukat. Az eredményeket a 3. táblázat foglalja össze.

\section{Megbeszélés}

Kutatásunk célja volt a békéscsabai szúrôprogramban részt vett nők mintáján felmérni a várandóssághoz kapcsolódó depresszió prevalenciáját, illetve összefüggést keresni a demográfiai adatokkal. Az Okagbue és mtsai [1] áttekintő tanulmányában található adatokhoz viszonyítva a békéscsabai mintán az első két trimeszterben jelentősen magasabb a depressziós tünetekkel küzdő nók aránya ( $15,31 \%$ és $14,29 \%$ a $10,35 \%$-hoz és 6,58\%-hoz képest). A harmadik trimeszterben a külföldi cikkben megugrik a prevalencia $(26,7 \%)$, míg a békéscsabai mintán tovább csökken (11,87\%). A szülés utáni időszakban Békéscsabán kissé megemelkedik a patológiás arány $(12,68 \%)$ : ez már közel hasonló a külföldi áttekintő tanulmány $14 \%$-os adatához, de még mindig magasabb az európai 8\%-os átlaghoz képest [2]. A 2017. évi szegedi kutatás patológiás 
4. táblázat |A patológiás arányok összefoglalása

\begin{tabular}{|c|c|c|c|c|c|}
\hline & 1. trimeszter & 2. trimeszter & 3. trimeszter & Postpartum & Összes kitöltés \\
\hline Okagbue et al. [1] & $10,35 \%$ & $6,58 \%$ & $26,7 \%$ & - & - \\
\hline Shorey et al. [2] - összesített & - & - & - & $14 \%$ & - \\
\hline Shorey et al. [2] - Európa & - & - & - & $8 \%$ & - \\
\hline Szombathely, 2009 [3] & $17,9 \%$ & - & - & - & - \\
\hline Békéscsaba, 2014 [4] & $9,3 \%$ & $12,8 \%$ & $9,3 \%$ & $17,5 \%$ & $11,2 \%$ \\
\hline Szeged, 2014 [4] & $12 \%$ & $6 \%$ & $6,4 \%$ & $8,2 \%$ & $8,9 \%$ \\
\hline Szeged, 2017 [5] & $10,8 \%$ & $6,9 \%$ & $6,5 \%$ & $7,8 \%$ & $8,5 \%$ \\
\hline Dél-Alföld, 1996 [15] & - & - & - & $14,9 \%$ & - \\
\hline Dél-Alföld, 2006 [15] & - & - & - & $17,4 \%$ & - \\
\hline Békéscsaba, 2019 & $15,31 \%$ & $14,29 \%$ & $11,87 \%$ & $12,68 \%$ & $14,31 \%$ \\
\hline
\end{tabular}

arányához $(10,8 \%, 6,9 \%, 6,5 \%$ és 7,8\%) [5] képest is magasabbak a jelenlegi értékek. A szombathelyi kutatás első trimeszterében mért 17,9\%-hoz [3] képest kissé alacsonyabb a békéscsabai minta $15,31 \%$-os prevalenciája, bár a különbség feleakkora, mint a külföldi összefoglaló tanulmánytól [1] vagy a szegedi mintától [5] való eltérés. A Dél-alföldi régióban végzett korábbi kutatások eredményeihez képest a jelen kutatásban minden mérési alkalom során magasabb a prevalencia, kivéve a 2014-es békéscsabai postpartum időszakot (17,5\% a 12,68\%-hoz képest) [4]. Az összes kitöltött kérdőívből Szegeden 2014-ben 8,9\% [4], 2017-ben 8,5\% [5] mutatott határérték feletti depresszióértéket; Békéscsabán 2014-ben 11,2\% [4], a jelen mintában pedig 14,31\%. Emellett a Dél-alföldi régióban a Leverton-kérdőívvel végzett postpartum felmérések alapján 1996-ban a nók 14,9\%-a, míg 2006-ban a 17,4\%-a szenvedett emelkedett depressziós tünetektól [15] (4. táblázat).

A különbségek adódhatnak az eltérő kulturális háttér, a különböző mérőeszközök miatt (például a szombathelyi kutatásban a Beck Depresszió Kérdőívet használták [3], a dél-alföldi kutatásban a Leverton-kérdőívet [15], míg Szegeden és Békéscsabán az EPDS-kérdőívet [4, 5]), vagy akár azért, mert a várandósság különböző hetében került sor az adatfelvételre. Viszont érdekes az idő előrehaladtával történő változás. A második trimesztert általában a legnyugodtabb időszaknak szokták jellemezni eredményeik alapján a kutatók, ami érthető is, hiszen ebben az időszakban már csökkennek vagy elmúlnak a rosszullétek, illetve kezd kialakulni a kapcsolat a magzattal [16] - ez magyarázhatja a patológiás arány csökkenését. A harmadik trimeszterben viszont általában újra megemelkednek a pontszámok és a patológiás arány, hiszen kialakulhat a szüléstől való félelem, nő a haskörfogat, nehezebbé válhat a mozgás, az alvás [16]: ez a külföldi mintán [1], illetve a 2014-es szegedi adatokon [4] követhető is. A 2017 utáni magyar mintákon azonban továbbra is csökken a prevalencia, csupán a szülés után emelkedik meg enyhén. Véleményünk szerint ez a csök- kenő tendencia annak köszönhető, hogy elindult a szűrőprogram, melynek kezdettől fogva szoros része volt a kiszűrt személyeknek biztosított pszichológiai intervenció. Egyrészt azért, mert ténylegesen lehetőségük van az érintett nőknek pszichés segítséget kérni; másrészt lehetséges, hogy már annak az ismeretnek az elterjedése is segíthet a várandósoknak, édesanyáknak, hogy ennek az időszaknak nehézségei is vannak, természetes dolog, ha időnként rosszul érzik magukat, ugyanakkor elérhető a segítség, ha szükségét érzik. Az is előfordulhat, hogy az évek óta tartó szúrőprogram a környezetüket is érzékenyebbé tette ezekre a tünetekre, azok észrevételére, így a nők több támogatást kapnak. Ugyanakkor még mindig a nők 18,27\%-a szenved emelkedett depressziós tünetektől legalább egyszer a várandósság során vagy a szülés után, illetve a patológiás értéket elért kérdőívek aránya is magasabb az eddig mértekhez képest, s ezek megerősítik a szűrés fontosságát.

Eredményeink szerint a mérési alkalmak depressziószintje pozitívan korrelált egymással, tehát akinek magasabb volt az EPDS-pontja valamelyik mérési alkalommal, annak valószínúleg a többi alkalom során is magasabb volt. A korábbi szakirodalmi közlemények szintén úgy találták, hogy az antepartum depresszió a postpartum depresszió rizikófaktora $[5,8]$. Ez azt jelzi, hogy magától nem igazán múlik el a probléma, ami szintén megerősíti a szűrés és a pszichológiai intervenció fontosságát.

A két nagy áttekintő tanulmányhoz $[1,2]$ hasonlóan a mi mintánkon is rizikófaktornak bizonyult a nem tervezett várandósság, illetve az egyedülálló családi állapot (bár ez utóbbi csak az első trimeszterben volt szignifikáns). Mindkettő magyarázható azzal, hogy a gyermekvállalásra fel kell készülni, hiszen az változásokat hoz az emberek életébe. Nem tervezett várandósság esetén kevesebb lehet az erre szánt idő, a sürgetettség érzése alakulhat ki; ráadásul külön nehézséget jelenthet annak eldöntése, hogy szeretnék-e megtartani a terhességet. Az egyedülálló nők esetén pedig előfordulhat, hogy kevesebb támogatást kapnak, egyedül maradnak a feladatokkal. 
A paritás esetén az átfogó tanulmányok inkonzisztens eredményre jutottak: egyes kutatásokban ugyanis nem találtak összefüggést ezekkel a változókkal, más kutatások pedig egymásnak ellentmondó következtetésekre jutottak $[1,2]$. A paritás a békéscsabai mintán nem bizonyult rizikófaktornak, csupán tendenciaszerü kapcsolatot találtunk a második trimeszterben: a multiparáknak tendenciaszerúen magasabb volt az EPDSrangátlaguk. A 2017. évi szegedi kutatásban ehhez hasonlóan a várandósság alatt végig a multiparáknak volt magasabb az EPDS-pontjuk, bár csak a harmadik trimeszterben volt szignifikáns a különbség, a másik kettőben csak tendenciaszerú. Elképzelhetőnek tartjuk, hogy a már meglévő gyerek, annak ellátása mellett kevésbé tudnak a nők az új magzatra koncentrálni, átadni magukat a várandósság örömeinek, így magasabb a depresszióértékük [5].

$\mathrm{Az}$ életkor vizsgálatával szintén inkonzisztens eredményre jutottak az átfogó vizsgálatok [1, 2]. A mi eredményeink szerint a békéscsabai mintában az első két trimeszterben van szignifikáns különbség; bár a páros összehasonlítás csak az első trimeszterben lett szignifikáns: a 21 év alatti nóknek volt szignifikánsan magasabb EPDS-rangátlaguk a többi négy csoporthoz képest. Elképzelhető, hogy ebben az életszakaszban még kevésbé érzik magukat a nók késznek a gyermekvállalásra, így ambivalenciát okozhat, hogy választaniuk kell: továbbtanulnak, vagy anyává válnak? Viszont ahogy halad előre a várandósság, egyre csökkennek a különbségek, talán a kialakult anya-magzat kapcsolat, valamint a társas támogatás megtalálása következtében.

A kutatás korlátai közé tartozik a lemorzsolódás: az idő előrehaladtával egyre kevesebb a részt vevő nő, hiszen előfordulhat költözés, a magzat elvesztése, vagy akár csak betegség vagy egyéb miatt is elmaradhat a kitöltés. Előfordulhat olyan eset is, amikor az első trimeszterben a kitöltés sine morbo eredményt mutat, így a védőnő a továbbiakban figyeli az esetleges depresszió tüneteit, de csak akkor tölteti ki újra a kérdőívet, ha patológiát gyanít.

\section{Következtetés}

Összességében elmondható, hogy a dél-alföldi mintákban emelkedett patológiás arányt találtunk, emellett a depressziószint elég állandónak túnik az eredmények alapján. Ez megerősíti a szűrés és a pszichológiai intervenció fontosságát, hiszen számos, a várandóssággal, a szüléssel és a későbbi élettel kapcsolatos komplikációval találtak már összefüggést korábbi kutatások. Az eredmények alapján egyes demográfiai jellemzők (2l év alatti életkor, egyedülálló családi állapot, a várandósság nem tervezettsége) rizikófaktorai lehetnek a megemelkedett EPDS-pontszámoknak, melyek mutathatják, hogy mely csoportokra érdemes nagyobb figyelmet fordítani a megelőzés, kezelés során.
Anyagi támogatás: A közlemény megírása anyagi támogatásban nem részesült.

Szerzôi munkamegosztás: H. E. A.: Irodalomkutatás, a kézirat megszövegezése, a statisztika elkészítése. G. N.: A szűrés vezetése és a pszichológiai intervencióra jelentkező nők ellátása három éven keresztül. B. L.: Szakmai lektorálás, a szúrés intézményi támogatása. T. A.: Témafelvetés, a kézirat szakmai értékelése, lektorálása, a szürés vezetése, a pszichológiai intervencióra jelentkező nők ellátása. A cikk végleges változatát valamennyi szerző elolvasta és jóváhagyta.

Érdekeltségek: A szerzőknek nincsenek érdekeltségeik.

\section{Köszönetnyilvánítás}

Köszönetünket fejezzük ki a békéscsabai védőnőknek, akik a kérdőívek kitöltetésével és begyưjtésével jelentősen segítették munkánkat, és hozzájárulnak ahhoz, hogy a veszélyeztetett várandósok és édesanyák a megfelelő ellátásba kerüljenek.

\section{Irodalom}

[1] Okagbue HI, Adamu PI, Bishop SA, et al. Systematic review of prevalence of antepartum depression during the trimesters of pregnancy. Open Access. Maced J Med Sci. 2019; 7: 1555-1560.

[2] Shorey S, Chee CY, Ng ED, et al. Prevalence and incidence of postpartum depression among healthy mothers: a systematic review and meta-analysis. J Psychiatr Res. 2018; 104: 235-248.

[3] Bödecs T, Horváth B, Kovács L, et al. Prevalence of depression and anxiety in early pregnancy on a population based Hungarian sample. [A várandósság alatti depresszió és szorongás gyakorisága az első trimeszterben hazai mintán.] Orv Hetil. 2009; 150: 1888-1893. [Hungarian]

[4] Töreki A, Baloghné Fưrész V, Szenti Z, et al. The psychological screening process in the maternal care system. [A pszichológiai szűrés megjelenése a várandósgondozásban.] Magy Nőorv L. 2014; 77: 12-15. [Hungarian]

[5] Hompoth EA, Töreki A, Baloghné Fưrész V, et al. The risk factors of mood changing during the perinatal period. [A hangulati állapot alakulásának kockázati tényezői a perinatalis időszakban.] Orv Hetil. 2017; 158: 139-146. [Hungarian]

[6] Lancaster CA, Gold KJ, Flynn HA, et al. Risk factors for depressive symptoms during pregnancy: a systematic review. Am J Obstet Gynecol. 2010; 202: 5-14.

[7] Biaggi A, Conroy S, Pawlby S, et al. Identifying the women at risk of antenatal anxiety and depression: a systematic review. J Affect Disord. 2016; 191: 62-77.

[8] Leigh B, Milgrom J. Risk factor for antenatal depression, postnatal depression and parenting stress. BMC Psychiatry 2008; 8: 24.

[9] Plant DT, Pariante CM, Sharp D, et al. Maternal depression during pregnancy and offspring depression in adulthood: role of child maltreatment. Br J Psychiatry 2015; 207: 213-220.

[10] Hompoth EA, Pető Z, Fưrészné Balogh V, et al. Associations between depression symptoms, psychological intervention and perinatal complications. J Clin Psychol Med Settings 2019 May 29. doi: 10.1007/s10880-019-09632-4. [Epub ahead of print]

[11] Professional protocol of the Hungarian Ministry of Human Resources about the mother-baby-father unit treatment of mental disorders during the pre-, peri- and postnatal phase. [Az Emberi Erőforrások Minisztériuma szakmai irányelve a pre-, peri- és posztnatális mentális zavarok baba-mama-papa egységében történő kezeléséről.] Egészségügyi Közlöny 2017; 66: 11201167. [Hungarian] 
[12] Cox JL, Holden JM, Sagovsky R. Detection of postnatal depression. Development of the 10-item Edinburgh Postnatal Depression Scale. Br J Psychiatry 1987; 150: 782-786.

[13] Töreki A, Andó B, Keresztúri A, et al. The Edinburgh Postnatal Depression Scale: translation and antepartum validation for a Hungarian sample. Midwifery 2013; 29: 308-315.

[14] Töreki A, Andó B, Dudás RB, et al. Validation of the Edinburgh Postnatal Depression Scale as a screening tool for postpartum depression in a clinical sample in Hungary. Midwifery 2014; 30 911-918.

[15] Csatordai S. Progress in the prevention of postnatal depression: adaptation of the Leverton questionnaire. $\mathrm{PhD}$ thesis. [Előrelépések a posztnatális depresszió prevenciójában: a Leverton kérdőív alkalmazása. Doktori értekezés.] Semmelweis Egye- tem Patológiai Tudományok Doktori Iskola, Budapest, 2009. Available from: http://semmelweis.hu/wp-content/phd/phd_ live/vedes/export/csatordaisarolta.d.pdf.

[16] Belső N. Psychological disorders of the perinatal period. In: C Molnár E, Füredi J, Papp Z. (eds.) Obstetrical and gynecological psychology and psychiatry. [A perinatális időszak pszichés zavarai. In: C Molnár E, Füredi J, Papp Z. (szerk.) Szülészetnőgyógyászati pszichológia és pszichiátria.] Medicina Kiadó, Budapest, 2006; pp. 81-92. [Hungarian]

(Hompoth Emőke Adrienn, Szeged, Semmelweis u. 6., 6725 e-mail: hompothemoke@gmail.com)

\section{Pályázati felhívás}

Dr. Fehér János professzornak, a Semmelweis Egyetem II. sz. Belgyógyászati Klinikája volt igazgatójának, az Orvosi Hetilap volt főszerkesztőjének emlékére 2011-ben alapítvány létesült.

A Dr. Fehér János Emlékére Alapítvány fö célja a belgyógyászat, különösen a hepatológia szabad gyökös és immunológiai vonatkozású témaköreinek kutatása, fejlesztése, támogatása,

illetve ösztönzése oly módon, hogy az alapítvány kamatából fiatal egyetemi oktatók, PhD-hallgatók és orvostanhallgatók részesüljenek.

A pályázatok benyújtásának határideje: 2020. április 15.

A dolgozatot „Dr. Fehér János pályázat” megjelöléssel kell benyújtani, és a pályázathoz mellékelni kell a pályázó önéletrajzát is.

A dolgozatot a Dr. Fehér János Emlékére Alapítvány Kuratóriuma elnökének

(Dr. Hagymási Krisztina) vagy titkárának (Dr. Lengyel Gabriella) kell eljuttatni.

Beküldési cím: Semmelweis Egyetem, II. Belgyógyászati Klinika 1088 Budapest, Szentkirályi u. 46.

A díj odaítéléséről a kuratórium dönt. A díj átadására az Orosi Hetilap Markusovszky-ünnepségén kerül sor, ahol a nyertes pályázó 5 perces előadásban foglalhatja össze az eredményeit.

A cikk a Creative Commons Attribution 4.0 International License (https://creativecommons.org/licenses/by/4.0/) feltételei szerint publikált Open Access közlemény, melynek szellemében a cikk bármilyen médiumban szabadon felhasználható, megosztható és újraközölhető, feltéve, hogy az eredeti szerző és a közlés helye, illetve a CC License linkje és az esetlegesen végrehajtott módosítások feltüntetésre kerülnek. (SID_1) 
III. 


\title{
A hangulati állapot alakulásának kockázati tényezői a perinatalis időszakban
}

\author{
Hompoth Emőke Adrienn - Töreki Annamária dr. \\ Baloghné Fürész Veronika - Németh Gábor dr.
}

Szegedi Tudományegyetem, Általános Orvostudományi Kar, Szülészeti és Nőgyógyászai Klinika, Szeged

\begin{abstract}
Bevezetés: 2011 áprilisában bevezetésre került Szegeden a perinatalis depressziószürés. Célkitüzés: A depresszív tünetek mértékének felderítése, illetve a perinatalis hangulati állapotváltozás kockázati tényezőinek vizsgálata. Módszer: Az Edinburgh Postnatal Depression Scale kérdőívet védőnők adtak át négy alkalommal a 3849 résztvevőnek. Eredmények: Az első trimeszterben a legmagasabb az átlagpontszám (3,74), amely szignifikánsan eltér a többi mérési alkalométól. A patológiás arány is ebben az időszakban volt a legmagasabb (10,8\%). Pozitív, közepes erősségü korreláció volt a mérési alkalmak depressziópontjai között, illetve összefüggést találtunk a magasabb szúréspontszámok és az alacsonyabb születési súly között. A magasabb átlagpontszámokkal tendenciaszerú összefüggés mutatkozott az epiduralis érzéstelenítés esetén, szignifikáns pedig a nem tervezettség, a 26 év alatti vagy 34 év fölötti életkor, egyedülálló családi állapot és a multiparitás függvényében. Következtetések: Az első trimeszterben már kimutatható pszichés változások vannak, valamint összefüggés van a különböző szociodemográfiai faktorok és a pszichés mutatók között. Ennek elkerülése érdekében fontos a depressziószűrés és a pszichológiai intervenció. Orv. Hetil., 2017, 158(4), 139-146.
\end{abstract}

Kulcsszavak: depressziószűrés, várandósgondozás, védőnők

\section{The risk factors of mood changing during the perinatal period}

\begin{abstract}
Introduction: The screening of perinatal depression was introduced in Szeged in April 2011. Aim: Our aim was to assess the extent of perinatal mood changing and to explore the risk factors of it. Method: Perinatal nurses gave the Edinburgh Postnatal Depression Scale to the 3849 participants four times. Results: In the first trimester were the highest average scores (3.74) and pathological rate (10.8\%) compared to the other measurement occasions. There was a positive correlation between the scores of the measurement occasions. The higher average scores related to the epidural anesthesia almost significantly, but significantly to the low birth weight, unplanned pregnancies, younger and older age, single marital status and multiparity of the participant. Conclusions: Even the first trimester is sensitive to pathological mood changes, which besides with other factors could be risk factors to postpartum depression. To avoid this it is important to continue the screening and provide adequate help.
\end{abstract}

Keywords: depression screening, perinatal care, perinatal nurses

Hompoth, E. A., Töreki, A., B. Fürész, V., Németh, G. [The risk factors of mood changing during the perinatal period]. Orv. Hetil., 2017, 158(4), 139-146.

(Beérkezett: 2016. augusztus 15.; elfogadva: 2016. november 15.)

\section{Rövidítések}

BDI (Beck Depression Inventory) = Beck Depresszió Kérdőív; EPDS = Edinburgh Postnatal Depression Scale; SCID = Structured Clinical Interview for DSM-IV) strukturált klinikai interjú a DSM-IV-hez
A várandósság egy jelentős mérföldkőnek tekinthető a nők életében, amikor számos változás megy végbe biológiai szinten, illetve átalakul az életritmus és a fontossági sorrend is. Ebben az időszakban pszichés tünetek jelentkezhetnek, például lehangoltság. Magyarországon még 
kevés kutatás foglalkozott ennek vizsgálatával, így a teljes lakosságra vonatkozó előfordulási arányról nincs pontos adat [1]. A Hungarostudy felmérések szerint nő a depresszív tünetekkel küzdők száma: 1988-ban a felnőtt nők 25,8\%-a panaszkodott depresszív tünetekről, 1995-ben 33,3\%-uk, ebből súlyos tünetekre 3\%, illetve 7,7\% [2]. További emelkedés figyelhető meg a súlyos depressziós tünetekkel küzdők arányában 2002 és 2006 között is, 10,7\%-ról 14,2\%-ra nőtt [3]. A külföldi szakirodalom szerint ez a tünetegyüttes a várandós nők mintegy $20 \%$ át érinti [4].

Hazai, kisebb régiót érintő kutatásokat folytattak Szeged, Békéscsaba és Szombathely térségében. A szombathelyi vizsgálat a Beck Depresszió Kérdőív (BDI) rövidített, kilenctételes változatával történt, az eredmények alapján pedig a minta $17,9 \%$-a jelzett depresszív tüneteket, közülük 1\%-ban voltak ezek súlyosak [1,5].

A szegedi és békéscsabai kutatásokban az Edinburgh Postnatal Depression Scale (EPDS) [6] kérdőívet használták, amit Töreki és mtsai validáltak 2010-2011-ben szegedi várandós és postpartum mintán. A validálás során a SCID diagnosztikai interjú felhasználásával külön határértéket állapítottak meg az ante- és postpartum mintákon a major és kombinált depresszió felmérésére a specificitás és szenzitivitás mutatók figyelembevételével $[7,8]$. Ezeket a határértékeket alkalmazva 2010-ben a szegedi antepartum mintán $6,85 \%$-ban voltak minor tünetek, $3,2 \%$-ban pedig major tünetek; míg a postpartum időszakban $13,5 \%$ volt a minor és $3 \%$ a major tüneteket mutatók aránya [9]. Szegeden és Békéscsabán 2011-ben ezek az arányok a következóképp alakultak: kóros értéket a szegedi minta $8,9 \%$-a és a békéscsabai mintal1,2\%a ért el [10].

A perinatalis depresszió kialakulásának több rizikófaktora is van, többek között a nem tervezett várandósság [11-14], a fiatalabb életkor [1, 13, 15], illetve, ha egyedülálló vagy özvegy az illetô $[11,14,15]$. Ugyanakkor a primiparitás rizikócsökkentő hatású lehet [11].

Több kutatás is vizsgálja a kezeletlen anyai depresszió hatását, összefüggéseit. Ezek eredményei szerint a depressziónak kapcsolata van a koraszüléssel [16], alacsony születési súllyal [17] és a gestatiós diabetesszel is [18]. Ezek a szövődmények az utód későbbi életére is hatással lehetnek: a koraszülés például növeli a felnőtt utódnál a depresszió [19] és a szkizofrénia [20] kialakulásának valószínúségét, az alacsony születési súly pedig a halvaszületés és a csecsemőhalálozás esélyét növeli [21], illetve felnőttkorban érrendszeri problémákhoz és 2-es típusú diabeteshez vezethet [22].

Emellett korábbi kutatások szerint az antepartum idószakban mért depresszió mértéke előre jelezheti a postpartum depresszió kialakulását [23]. Chung és mtsai [24] eredményei szerint pedig a harmadik trimeszterben mért nagyobb depressziópontszámok esetén nagyobb volt a valószínúsége, hogy a szüléskor epiduralis érzéstelenítést alkalmaztak.
A kutatás célja az volt, hogy megvizsgáljuk, a magyar mintán hogyan alakulnak a depresszió-átlagpontszámok, illetve található-e összefüggés a depresszív tünetek és a perinatalis szövődmények között. Hipotéziseink a következők voltak:

1. Pozitív kapcsolat van az antepartum és postpartum depresszív pontszámok között.

2. Összefüggés van az alacsony születési súly és a magasabb depresszív pontszámok között.

3. A harmadik trimeszterben a magasabb depressziópontszámot elérő nők nagyobb valószínúséggel igényelnek epiduralis érzéstelenítést a szüléskor.

4. Egyes demográfiai jellemzők (fiatalabb életkor, egyedülálló családi állapot és a multiparitás), valamint a várandósság nem tervezettsége szintén kapcsolatban állnak a magasabb depresszív pontszámokkal.

\section{Módszer}

\section{A minta}

A kutatásban azoknak a személyeknek az adatait használtuk fel, akik a 2011 áprilisában Szegeden elindult perinatalis depressziószúrésben vettek részt. Eddig összesen 3849 kitöltő volt. Egyetlen kizáró tényezője a szűrésben való részvételnek, ha nem beszélt magyarul, emellett fiatalkorú anya részvételéhez szülői beleegyezést kértünk. A legfiatalabb személy 13 éves volt, a legidősebb 43 éves, az átlagéletkor 30,58 év volt $(S D=5,060)$. A legtöbben élettársi kapcsolatban vagy házasságban éltek (1048 és 1780 fö). A legtöbben elöször szülők voltak (1969 fó), 1085 személynek volt egy és 318-nak kettő gyermeke, míg a többieknek három vagy annál több. Az esetek 87,5\%-ában volt szó tervezett terhességről.

$\mathrm{Az}$ alacsony születési súly, valamint az érzéstelenítés módja és a depressziópontok kapcsolatának vizsgálatához egy almintát hoztunk létre: 1325 fő adatait gyưjtöttük ki eddig a beteg-nyilvántartási rendszerből, közülük 129 személyt zártunk ki az elemzések során ikerszülés miatt, illetve, ha más klinikán szült, így az adataihoz nem volt hozzáférésünk. Az almintában az átlagéletkor 30,5 év volt $(S D=4,964)$. A legtöbben élettársi kapcsolatban vagy házasságban éltek (338 és 556 fơ). A többség először szülő volt (628 fó), 351 személynek volt egy gyermeke, 98-nak kettő és 34 nőnek volt három vagy annál több gyereke. Az esetek 88,9\%-ában volt szó tervezett terhességról.

\section{Eszközök, a szürés folyamata}

A szűrésben az EPDS [6] kérdőívet használtuk, amely egy rövid, három-öt perc alatt kitölthető kérdőív. Tíz kérdése az elmúlt hét hangulati állapotára vonatkozik: érzett-e lehangoltságot, szorongást, összecsaptak-e feje fölött a hullámok stb. Emellett a tizedik kérdés a szuicid gondolatokat méri fel. Mindegyik kérdésre négy lehetséges válasz van, amelyekre 0-3 pont közötti értéket lehet 
adni, így a teljes kérdőív összpontszáma 0-30 közötti lehet.

A megállapított ponthatárok a 7 és 12 pont: 7 pont felett minor, 12 pont felett major depressziót valószínúsít a kérdóív a korábbi validálási eljárásunk alapján $[7,8]$. Mindkét esetben, illetve akkor is, ha a tizedik kérdésen akár csak egy pontot is kap a kitöltő, akkor javaslatot kap a pszichológus felkeresésére, amelyról szabadon dönthet, hogy él-e a lehetőséggel. A pszichológus szupportív módszer mellett a következőket alkalmazza: tanácsadás, relaxáció, szülésre felkészítés, edukáció stb., a módszer igazodik az adott időszak nehézségeihez, trimeszterspecifikusan történik a kezelés.

A szưrésben a védőnőknek kulcsfontosságú a szerepük: ők adják át a tájékoztató és beleegyező nyilatkozatot a várandósoknak az első találkozás alkalmával, ez után a demográfiai adatok felvételére kerül sor, majd pedig az EPDS kérdőív kitöltésére. A második és harmadik trimeszterben, illetve egyszer a postpartum időszakban újra megtörténik az EPDS kitöltése, így biztosítva a lehetôséget az esetleges változások követésére (1. ábra). A kérdőíveket a védőnők kiértékelik, majd eljuttatják a szürésben részt vevő pszichológushoz, aki a beteg-nyilvántartási rendszerben rögzíti az eredményeket, így a szűrés Szegeden már a várandósgondozás részévé vált.

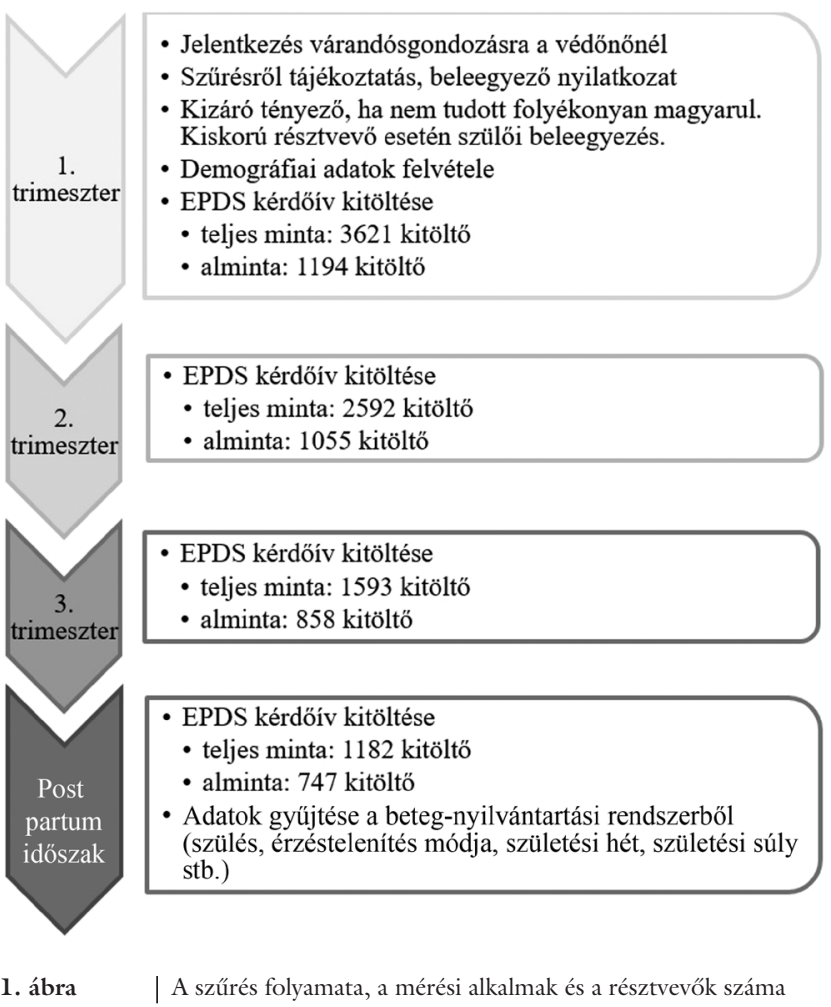

\section{Statisztika}

Mivel a mérési időszakok esetén a résztvevők száma jelentősen különbözik, így kétféle módszert alkalmaztunk annak felderítésére, hogy szignifikáns különbség van-e az EPDS-átlagpontszámokban. Egyrészt ismételt méréses
ANOVA-t használtunk, amit akkor alkalmaznak, ha ugyanazt a mérést végzik el bizonyos időközönként ugyanazon személyek részvételével. A másik módszer az egyszempontos ANOVA, amely egymástól független csoportok között elemzi az átlagpontszámok különbségét.

$\chi^{2}$-próbát is használtunk, amely alkalmas annak elemzésére, hogy a különböző feltételek alapján létrehozott csoportok között az elemszámok különbsége a véletlennek köszönhető vagy valószínúsíthető a háttérben valamilyen hatás. Ezt a születési súly és EPDS-pontok közötti kapcsolat elemzésére használtuk, a következő csoportosítással: alacsony születési súly $(<2500 \mathrm{~g})$, illetve normális születési súly ( $\geq 2500 \mathrm{~g}$ ); emellett kontroll (akik 0-7 EPDS-pontot értek el), minor (8-12 EPDS-pont) és major csoport ( $\geq 13$ EPDS-érték). Mivel az EPDS kérdőív validálása a SCID diagnosztikai interjú alapján történt $[7,8]$, ezért megalapozottan lehet állítani, hogy a 7 pont feletti értéket elérő személyeknél minor depresszió állhat a háttérben, 12 pont felett pedig major depresszió valószínúsíthetô. A besorolást a kutatási adatok feldolgozásához használjuk, nem diagnosztikus értékú.

Egyszempontos ANOVA-val elemeztük azt, hogy az EPDS-pontok alapján alakított csoportok (kontroll-, minor, major csoport) között a születési súlyok átlagában van-e szignifikáns különbség. Emellett annak felderítésére alkalmaztuk, hogy az EPDS-átlagpontszámok között van-e különbség a Lee és mtsai [15] által is alkalmazott életkor-csoportosító változó tekintetében ( $\leq 25$ éves vs. 26-34 éves vs. $\geq 35$ éves résztvevők).

$\mathrm{Az}$ ante- és postpartum depresszió kapcsolatának elemzéséhez korrelációt használtunk az EPDS-pontszámokon, mivel ez a módszer együttjárás felderítésére alkalmas, és a szakirodalom [23] szerint a postpartum depressziónak rizikófaktora (és nem oka) az antepartum depresszió, tehát a kettő közt együttjárás található.

Független mintás t-próbát is alkalmaztunk annak felderítésére, hogy van-e különbség az EPDS-pontszámokban a születési súly (alacsony vs. normál), illetve az érzéstelenítés (epiduralis érzéstelenítés vs. egyéb érzéstelenítő), mint csoportosító változók esetén. Emellett a demográfiai jellemzők, mint a várandósság tervezettsége (tervezte vs. nem tervezte), családi állapot (egyedülálló/elvált/ özvegy vs. házassági/élettársi kapcsolatban él), illetve paritás (először vs. többedszer szülő) csoportosító változók és EPDS-pontszámok közötti kapcsolat felderítésére is ezt alkalmaztuk.

\section{Eredmények}

A szúrés kezdetén a várandósoknak csupán egyharmada töltötte ki a kérdő́iveket, manapság már közel 90\%-os a részvételi arány. A kitöltések átlagosan a 11., 23. és 35. héten történtek, a postpartum időszakban pedig a 4-6. héten.

Ismételt méréses ANOVA-val elemeztük, hogy hogyan alakulnak az EPDS-pontszámok a mérési alkalmak 

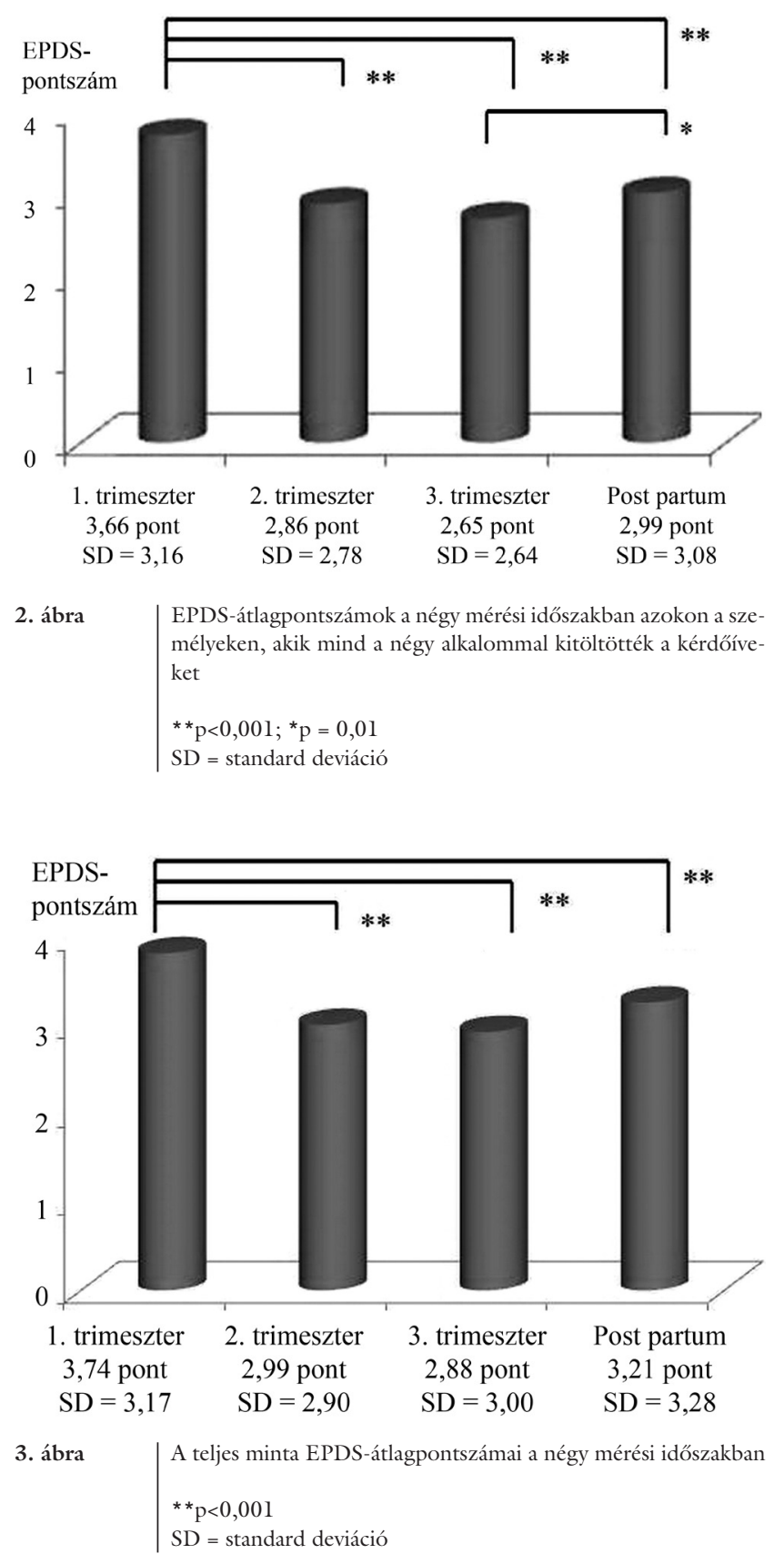

során annál az 587 fö́t tartalmazó csoportnál, akik mind a négy alkalommal kitöltötték a kérdő́ivet. Eredményeink szerint a mérési alkalmak átlagpontszámai egymástól szignifikánsan eltérnek, $\mathrm{F}(2,579,1511,577)=27,832$, $\mathrm{p}<0,001$. A Bonferroni post hoc teszt szerint az első mérési alkalom átlagpontszáma a legmagasabb és mindhárom továbbitól szignifikánsan eltér $(\mathrm{p}<0,001)$, emellett szignifikáns eltérés volt a harmadik és negyedik mérési alkalom között $(\mathrm{p}=0,010)$ (2. ábra).

Az egész mintára kiterjesztve a vizsgálatot egyszempontos ANOVA-val hasonló eredményt kaptunk: a négy alkalom között szignifikáns volt az eltérés, $\mathrm{F}(3,8623)=39,093, \mathrm{p}<0,001$. A Bonferroni post hoc teszt szerint az első mérési alkalom különbözött szignifikánsan a többi háromtól $(\mathrm{p}<0,001)(3 . a ́ b r a)$.

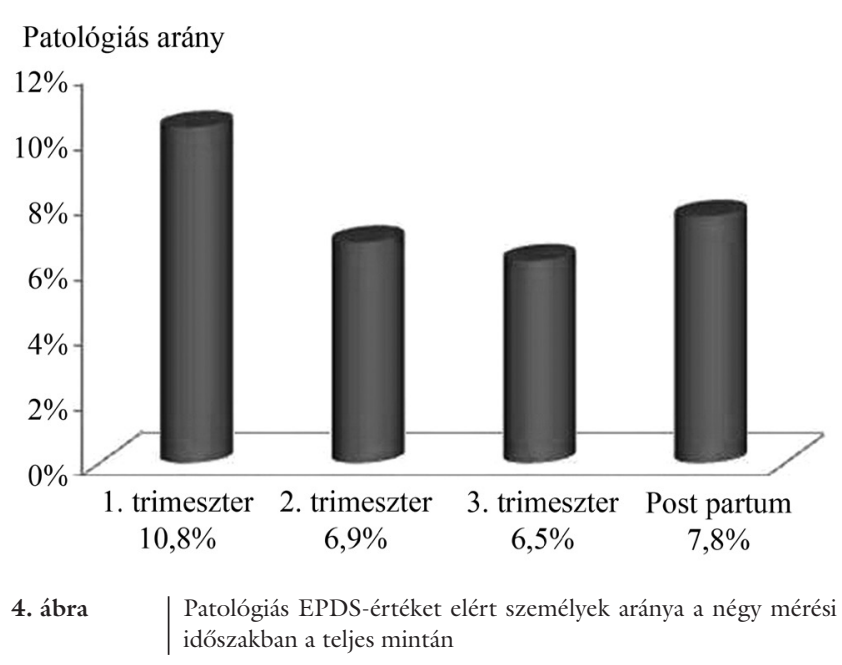

A patológiás arány vizsgálatához annak a 731 kitöltésnek a pontszámait vettük figyelembe, ahol az érték hétnél nagyobb volt, ez az összes kitöltés 8,5\%-a. Az első trimeszter kitöltő́inek $10,8 \%$-a, a második trimeszter $6,9 \%$-a, a harmadik trimeszter $6,5 \%$-a, a postpartum időszakban pedig 7,8\%-a volt patológiás a kitöltéseknek (4. ábra).

Korrelációval vizsgáltuk az almintán a négy mérési alkalom depressziópontszámait, eredményeink szerint mind a négy egymással pozitívan, közepesen erősen, szignifikánsan összefüggött $(0,396<\mathrm{r}<0,652, \mathrm{p}<0,001)$.

Tanulmányoztuk a születési súly és az EPDS-pontok kapcsolatát $\chi^{2}$-próbával. Eredményeink szerint a harmadik trimeszterben minor csoportban (43 fó) 9,3\%-ban, major csoportban ( 8 fó) 12,5\%-ban lett alacsony születési súly (25 eset), míg a kontrollcsoportban csak 2,6\%ban, a különbség szignifikáns $\left(\chi^{2}(2)=8,198, \mathrm{p}=0,017\right)$. \begin{tabular}{l|l} 
1. táblázat & $\begin{array}{l}\text { Az alacsony és normális születési súly eloszlása a hangulati állapot } \\
\text { szerint }\end{array}$
\end{tabular}

\begin{tabular}{cccc}
\hline $\begin{array}{c}\text { Kontroll } \\
\text { csoport }\end{array}$ & $\begin{array}{c}\text { Minor } \\
\text { csoport }\end{array}$ & $\begin{array}{c}\text { Major } \\
\text { csoport } \\
(0-7 \text { pont })\end{array}$ & p-érték \\
& $(8-12$ pont $)$ & $(13-30$ pont $)$ & \\
\hline
\end{tabular}

\section{3. trimeszter}

Alacsony

születési súly

(2500 g alatt)

\begin{tabular}{ccc}
\hline $\begin{array}{c}\text { Minor } \\
\text { csoport } \\
(8-12 \text { pont })\end{array}$ & $\begin{array}{c}\text { Major csoport } \\
(13-30 \text { pont })\end{array}$ & p-érték \\
\hline
\end{tabular}

\section{Postpartum}

idószak

Alacsony $\quad 14,8 \% \quad 7,4 \%$

születési súly

(2500 g alatt)

Normális

$4,7 \%$

0,007 *

születési súly

(2500 g vagy

a fölött)

${ }^{*} \mathrm{p}<0,05$ 

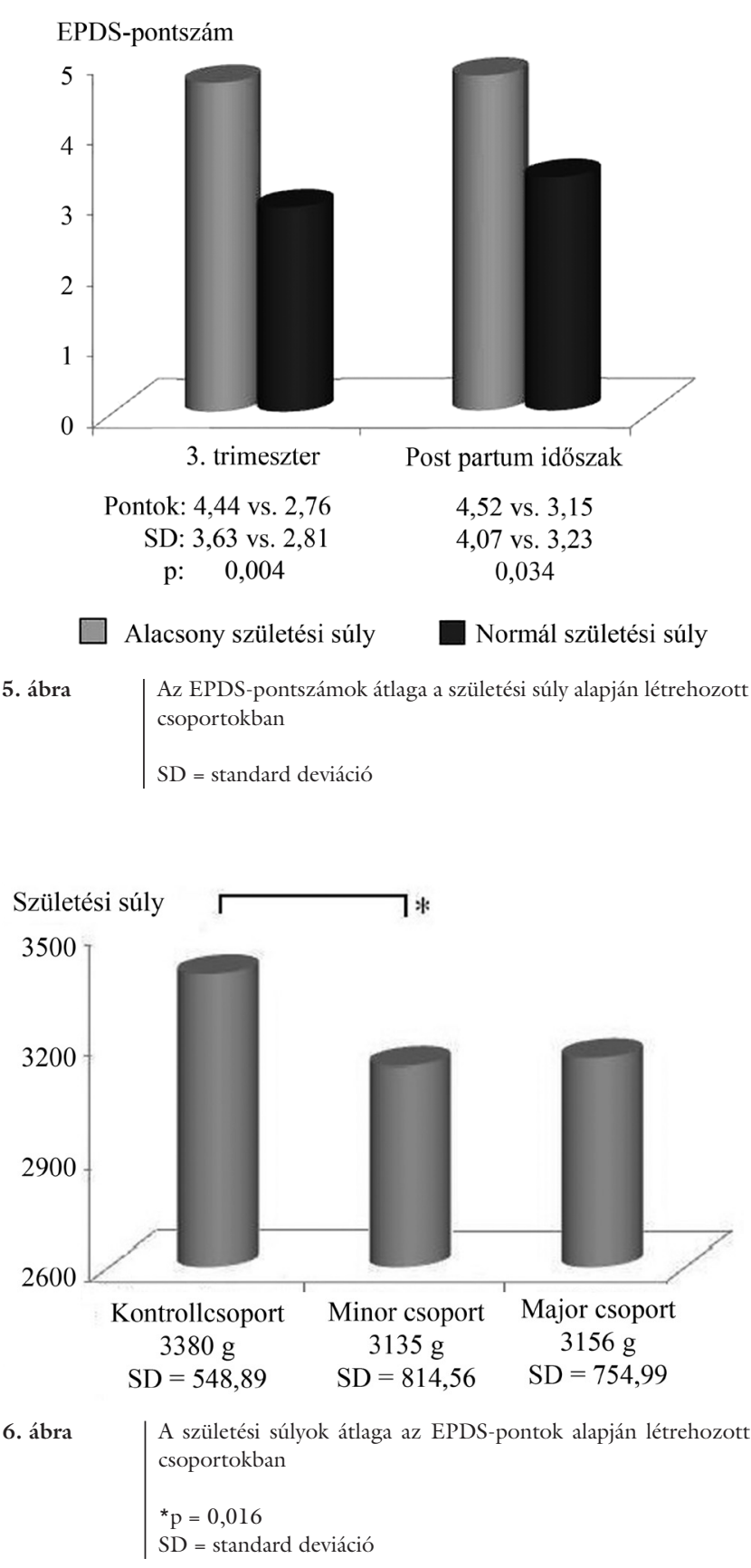

A postpartum időszakban pedig az alacsony születési súly csoportban (27 fó) 14,8\%-ban (4 fö) alakultak ki minor tünetek (EPDS 7-12 pont), 7,4\%-ban (2 fö) major tünetek (EPDS 13-30 pont), míg a normális születési súlyú csoportban csak 4,7\%-ban (32 személy) és 1,8\%ban (12 személy) $\left(\chi^{2}(2)=9,927, p=0,007\right)$ (1. táblázat).

Független mintás t-próba szerint pedig az alacsony születési súlyú csoportban (25 és 27 fó) a normális születési súlyú csoporthoz képest szignifikánsan magasabb az EPDS-pontok átlaga a harmadik trimeszterben $(4,44$ pont, $S \mathrm{SD}=3,63$ vs. 2,76 pont, $S \mathrm{SD}=2,809)$ és a postpartum időszakban is $(4,52$ pont, $\mathrm{SD}=4,07$ vs. 3,15 pont, $\mathrm{SD}=3,23)(\mathrm{t}(795)=2,916, \mathrm{p}=0,004$ és $\mathrm{t}(699)=2,129$, $\mathrm{p}=0,034)(5$. ábra $)$.
Az EPDS-pontok alapján kialakított csoportok (kontroll vs. minor vs. major) között a születésisúly-átlagok különbségének vizsgálatára alkalmaztuk az egyszempontos ANOVA-t. Eredményeink szerint szignifikánsan magasabb volt a kontrollcsoportban (654 fö) a születési súly (átlag $=3379,65, \mathrm{SD}=548,89$ ) a minor csoporthoz képest ( 37 fó, súly átlaga $=3134,73, \mathrm{SD}=814,56)(\mathrm{F}(2$, $702)=4,172, \mathrm{p}=0,016)$. Azonban a major csoporttól ( 14 fó, súly átlaga $=3155,71, \mathrm{SD}=754,991)$ egyik sem tért el szignifikánsan (6. ábra).

Független mintás t-próbát használtunk az érzéstelenítés típusa (epiduralis vs. egyéb) csoportosító változó és az EPDS-átlagpontok közötti kapcsolat felderítésére. Eredményeink szerint azok a személyek, akik az epiduralis érzéstelenítést részesítették előnyben (179 fö) más módokhoz képest (1022 fó), azoknak tendenciaszerúen nagyobb volt az antepartum EPDS-pontszámuk átlaga $(3,82$ pont, $S D=2,79$ vs. 3,38 pont, $S D=2,82)$ $(t(1199)=1,909, p=0,056)$.

A független mintás t-próbát alkalmazva összefüggés mutatkozott az EPDS-átlagpontszámok és a várandósság tervezettsége (tervezte vs. nem tervezte) között: mind a négy mérési időszakban szignifikánsan magasabb volt az EPDS-pontok átlaga abban a csoportban, ahol nem volt tervezett a várandósság $(\mathrm{p}<0,014) \quad(2$. táblázat).

A családi állapot (egyedülálló/elvált/özvegy vs. élettársi/házastársi kapcsolatban él) és depressziós hangulat is szignifikánsan összefügg a független mintás t-próba szerint a második trimeszterben: akik egyedülállóak, azoknak magasabb az EPDS-átlagpontjuk azokhoz képest, akiknek van társuk, $\mathrm{t}(222)=2,280, \mathrm{p}=0,024$ (2. táblázat). Ez a tendencia jellemzó az elsô trimeszterre és a postpartum időszakra is, bár az összefüggés nem szignifikáns.

Az életkor hatásának vizsgálatára Lee [15] kutatásához hasonlóan három csoportra bontottuk a mintát $(\leq 25$ éves vs. 26-34 éves vs. $\geq 35$ éves). Egyszempontos ANOVA szerint csak a várandósság ideje alatt van szignifikáns különbség az életkori csoportok között az EPDSátlagpontszámokban $(\mathrm{p}<0,05)$. Az első, legfiatalabb csoportban volt a legmagasabb az átlagpontszám, ezt a harmadik, legidősebb csoport követte, majd a második. A Bonferroni post hoc teszt szerint a szignifikáns eltérés mindhárom trimeszterben az első és a második, illetve a második és a harmadik csoport között volt $(\mathrm{p}<0,049)$, azonban az első és a harmadik csoport nem tért el szignifikánsan egymástól (2. táblázat).

Független mintás t-próbával vizsgálva a paritáscsoportosító változó (primipara vs. multipara) és EPDS-átlagpontok közötti kapcsolatot a következő eredményt kaptuk: mind a négy mérési alkalommal alacsonyabb volt az EPDS-átlagpontszám a primipara-csoportban a multiparákhoz képest, azonban a különbség csak a harmadik trimeszterben volt szignifikáns $(\mathrm{t}(760)=-2,106$, $\mathrm{p}=0,036)$, emellett az első trimeszterben tendenciaszerú $(\mathrm{p}=0,051)$ (2. táblázat). 


\section{Megbeszélés}

Az eredményekből összességében az látszik, hogy az első trimeszterben a legmagasabb az EPDS-átlagpontszám, amely szignifikánsan különbözik a többi átlagpontszámtól. Enyhén magasabb, de hasonlóan váltakozó átlagpontszámokat kaptak Töreki és mtsai a korábban közölt eredményeikben szegedi mintán [10]. Ugyanakkor a békéscsabai mintán nemcsak enyhén magasabbak voltak az átlagpontszámok, hanem a postpartum trimeszterben volt a legmagasabb, amelyet az első trimeszter követett. Török eredményei [14] szerint 8,12 az EPDS-átlag a szülés utáni harmadik napon, 7,93 pedig 3-9 hónap múlva, összevetve a mi mintánk 3,66 és 3,74 pontjával. Az eltéréseket okozhatja a minták közötti elemszámkülönbség, valamint, hogy a jelenlegi vizsgálatban nagyobb arányban volt tervezett a várandósság, amely protektív faktor lehet a tünetekkel szemben [11-13]. Az eltérést okozhatta továbbá a kérdőív felvételének eltérő ideje.

Kutatásunkban a patológiás értéket elért személyek aránya $8,5 \%$, ebből az első trimeszterben volt a legmagasabb, 10,8\%. Bödecs mintájában [1] a résztvevők 17,9\%-a jelzett depresszív tüneteket, Töreki és mtsai 2013-ban [9] 10\%-ban és 16,5\%-ban, 2014-ben [10] szegedi és békéscsabai mintán $8,9 \%$-ban és 11,2\%-ban talált patológiás értéket. Török [14] postpartum résztvevői közt 29,8\%-ban, szülés után 3-9 hónappal pedig 31,5\%-ban (BDI-vel) és 28,7\%-ban (EPDS-sel) álltak fent patológi- ás mértékű tünetek. A jelentősebb eltéréseket okozhatja az elemszám, a használt eszközök és a mérés időpontjának a különbözősége, valamint a demográfiai változókban való eltérés: Koppés mtsai [2] szerint a Dunántúlhoz képest a Dunától keletre jelentősen magasabb a depreszszió-átlagpontszám, Csongrád megye kivételével.

Az eredményeink érdekessége még, hogy a patológiás pontot elértek átlaga az első trimeszterben a legmagasabb. Ezt és az átlagpontszámok hasonlóan alakuló tendenciáját okozhatja az, hogy a ponthatárértéket átlépő várandósoknak jelezték a védőnők a kialakuló depresszió lehetőségét, így ők ennek tudatában kérhettek segítséget a környezetüktől, illetve szakembertől. Az is lehetséges, hogy az első trimeszter a legérzékenyebb a depresszió kialakulására, de ennek megállapításához további vizsgálatok szükségesek. Az viszont már bizonyos az eredmények alapján, hogy nemcsak a postpartum időszak érzékeny a hangulatváltozásra, hanem már az első trimeszter is, ami azért nagyon fontos, mert ha tudjuk, hogy az érzékenység már az első trimeszterben kimutatható, akkor elkezdődhet a kezelés, így elkerülhetôvé válnak az esetleges későbbi szövődmények.

A statisztikai elemzés szerint, a szakirodalmi eredményekhez hasonlóan, bizonyos demográfiai jellemzők rizikófaktorai lehetnek a hangulatváltozásnak. Ilyen a nem tervezett várandósság, amely esetén eredményeink szerint mind a négy mérési időpontban szignifikánsan magasabbak voltak az EPDS-átlagpontszámok, akárcsak

2. táblázat |Az EPDS-átlagpontszámok és a demográfiai jellemzők összefüggései

\begin{tabular}{|c|c|c|c|c|c|c|c|c|c|c|c|c|}
\hline & \multicolumn{3}{|l|}{ 1. trimeszter } & \multicolumn{3}{|l|}{ 2. trimeszter } & \multicolumn{3}{|l|}{ 3. trimeszter } & \multicolumn{3}{|c|}{ Postpartum időszak } \\
\hline & Átlag & $\mathrm{N}$ & $\mathrm{p}$ & Átlag & $\mathrm{N}$ & $\mathrm{p}$ & Átlag & $\mathrm{N}$ & $\mathrm{p}$ & Átlag & $\mathrm{N}$ & $\mathrm{p}$ \\
\hline $\begin{array}{l}\text { Tervezett } \\
\text { terhesség } \\
\text { Igen } \\
\text { Nem }\end{array}$ & $\begin{array}{l}3,58 \\
(\mathrm{SD}=2,86) \\
5,45 \\
(\mathrm{SD}=3,95)\end{array}$ & $\begin{array}{l}989 \\
120\end{array}$ & $0,001 * *$ & $\begin{array}{l}2,84 \\
(\mathrm{SD}=2,69) \\
5,11 \\
(\mathrm{SD}=4,15)\end{array}$ & $\begin{array}{l}878 \\
103\end{array}$ & 0,001 * * & $\begin{array}{l}2,62 \\
(\mathrm{SD}=2,66) \\
4,64 \\
(\mathrm{SD}=4,03)\end{array}$ & $\begin{array}{l}720 \\
75\end{array}$ & 0,001 * * & $\begin{array}{l}2,96 \\
(\mathrm{SD}=2,86) \\
4,46 \\
(\mathrm{SD}=4,73)\end{array}$ & $\begin{array}{r}631 \\
67\end{array}$ & $0,013^{*}$ \\
\hline \multicolumn{13}{|l|}{ Életkor } \\
\hline$\leq 25$ év & $\begin{array}{l}4,37 \\
(\mathrm{SD}=3,24)\end{array}$ & 158 & \multirow{3}{*}{$\begin{array}{l}0,012^{*} \\
0,019^{*}\end{array}$} & $\begin{array}{l}4,08 \\
(\mathrm{SD}=3,73)\end{array}$ & 151 & \multirow{3}{*}{$\begin{array}{l}0,001 \text { ** } \\
0,048^{*}\end{array}$} & $\begin{array}{l}3,35 \\
(\mathrm{SD}=3,39)\end{array}$ & 120 & \multirow{3}{*}{$\begin{array}{l}0,019^{*} \\
0,013^{*}\end{array}$} & $\begin{array}{l}3,44 \\
(\mathrm{SD}=3,97)\end{array}$ & 99 & \multirow{3}{*}{$0,055^{\mathrm{t}}$} \\
\hline 26-34 év & $\begin{array}{l}3,56 \\
(\mathrm{SD}=3,12)\end{array}$ & 696 & & $\begin{array}{l}2,78 \\
(\mathrm{SD}=2,65)\end{array}$ & 641 & & $\begin{array}{l}2,56 \\
(\mathrm{SD}=2,58)\end{array}$ & 525 & & $\begin{array}{l}2,97 \\
(\mathrm{SD}=2,79)\end{array}$ & 461 & \\
\hline$\geq 35$ év & $\begin{array}{l}4,22 \\
(\mathrm{SD}=3,51)\end{array}$ & 223 & & $\begin{array}{l}3,38 \\
(\mathrm{SD}=3,22)\end{array}$ & 175 & & $\begin{array}{l}3,33 \\
(\mathrm{SD}=3,22)\end{array}$ & 141 & & $\begin{array}{l}3,71 \\
(\mathrm{SD}=3,86)\end{array}$ & 136 & \\
\hline \multicolumn{13}{|l|}{ Családi állapot } \\
\hline Egyedülálló & $\begin{array}{l}4,10 \\
(S D=3,47)\end{array}$ & 192 & \multirow[t]{2}{*}{0,115} & $\begin{array}{l}3,58 \\
(\mathrm{SD}=3,39)\end{array}$ & 168 & \multirow[t]{2}{*}{$0,024^{*}$} & $\begin{array}{l}2.52 \\
(\mathrm{SD}=2,57)\end{array}$ & & \multirow[t]{2}{*}{0,246} & $\begin{array}{l}3,26 \\
(\mathrm{SD}=3,61)\end{array}$ & 130 & \multirow[t]{2}{*}{0,556} \\
\hline Társsal él & $\begin{array}{l}3,7 \\
(\mathrm{SD}=3,08)\end{array}$ & 836 & & $\begin{array}{l}2,94 \\
(\mathrm{SD}=2,86)\end{array}$ & 759 & & $\begin{array}{l}2,82 \\
(\mathrm{SD}=2,84)\end{array}$ & 614 & & $\begin{array}{l}3,08 \\
(\mathrm{SD}=3,03)\end{array}$ & 538 & \\
\hline \multicolumn{13}{|l|}{ Paritás } \\
\hline Primipara & $\begin{array}{l}3,62 \\
(\mathrm{SD}=3,08)\end{array}$ & 587 & \multirow[t]{2}{*}{$0,051^{\mathrm{t}}$} & $\begin{array}{l}2,93 \\
(\mathrm{SD}=2,93)\end{array}$ & 536 & \multirow[t]{2}{*}{$0,084^{\mathrm{t}}$} & $\begin{array}{l}2,61 \\
(\mathrm{SD}=2,74)\end{array}$ & 441 & \multirow[t]{2}{*}{$0,036^{*}$} & $\begin{array}{l}3,11 \\
(\mathrm{SD}=3,13)\end{array}$ & 390 & \multirow[t]{2}{*}{0,845} \\
\hline Multipara & $\begin{array}{l}4,01 \\
(\mathrm{SD}=3,25)\end{array}$ & 449 & & $\begin{array}{l}3,27 \\
(\mathrm{SD}=3,04)\end{array}$ & 395 & & $\begin{array}{l}3,05 \\
(\mathrm{SD}=2,97)\end{array}$ & 321 & & $\begin{array}{l}3,16 \\
(\mathrm{SD}=3,26)\end{array}$ & 285 & \\
\hline
\end{tabular}

${ }^{*}{ }^{*} \mathrm{p} \leq 0,001 ;{ }^{*} \mathrm{p}<0,05 ;$

tendencia 
korábbi vizsgálatokban [11-13]. Török [14] eredménye alapján pedig a patológiás pontértékű csoportban nagyobb arányban van a nem tervezett várandósságok aránya a tervezetthez képest.

Rizikófaktor lehet a támogatás hiánya, egyedülálló családi állapot is $[11,15]$. A mi eredményeink szerint, akik egyedül éltek, azoknál a harmadik trimeszter kivételével mindhárom mérési alkalom esetén magasabb volt az EPDS-átlagpontszám, bár csak a második trimeszterben volt szignifikáns. Török szerint [14] a patológiás tüneteket mutató csoportban nagyobb arányban vannak egyedülállók a családosokhoz képest, Bödecs [1] pedig még az élettársi kapcsolathoz képest is pozitívabb hatásúnak találta a házassági kapcsolatot. Ezek a társas támogatás fontos szerepére mutatnak rá.

Eredményeink szerint a primiparitás rizikócsökkentő hatású lehet a depresszióval szemben, amelynek hátterében állhat, hogy akik többedik gyermeküket várják, ők kevésbé tudnak a várandósság élményszintű megélésére fókuszálni, hiszen már van gyerekük, akit (vagy akiket) el kell látniuk. Így elfoglaltabbak, megterhelőbb eljárniuk a szűrésekre. Ha pedig a korábbi terhességben volt valamilyen komplikáció, ez külön distresszt okozhat [13]. Török [14] szerint szintén lehet az először szülésnek egyfajta protektív hatása, hiszen eredményei szerint a kóros EPDS-csoportban a legkisebb arányban a primiparák voltak.

Az életkor és EPDS-pontszámok kapcsolatának elemzésekor azt az eredményt kaptuk, hogy a fiatalabb életkor összefügg a magasabb átlagpontszámmal, hasonlóan korábbi kutatásokhoz [1, 13, 15]. Ugyanakkor a mi mintánkon a 26-34 éves korosztálynak van a legalacsonyabb átlagpontszáma, ehhez képest 34 éves kor fölött újra megemelkednek az EPDS-átlagpontszámok, míg Töreki [13] eredményei szerint a 35 év feletti időszak a legkevésbé veszélyeztetett a hangulatváltozásra. A mi eredményeink eltérését okozhatják a demográfiai tényezők, valamint a kutatásban használt eszközök eltérése. $\mathrm{Az}$ is lehetséges, hogy a korábbi vizsgálatok óta növekedtek az idősebb anyákra nehezedő terhek, amelyek sérülékenyebbé tehetik őket a depresszív tünetek kialakulására.

Eredményeink szerint emellett összefüggés van a születési súly és az EPDS-pontszámok között: a harmadik trimeszterben és a postpartum időszakban az alacsony születési súlycsoportban magasabb az EPDS-átlagpontszám, illetve nagyobb arányban fordul elő minor és major súlyosságú tünetegyüttes. Ez megerősíti Rahman eredményeit [17], ami szerint a depressziós anyáknak szignifikánsan kisebb lett az újszülöttje a nem depressziós anyákhoz képest. Illetve megerősíti Török eredményét [14] is, amely szerint az alacsony születési súly jelentős rizikófaktor a postpartum időszakban a kóros mértékú depresszív tünetek kialakulására.

Eredményeink megerôsítették korábbi kutatások eredményeit [24,25], miszerint az antenatalis depresszió nö- veli annak valószínűségét, hogy a szülés levezetéséhez epiduralis érzéstelenítőt kérnek a vajúdó nők. Ennek hátterében az állhat, hogy a megnövekedett fájdalomérzet - amely a depresszív állapotok velejárója [26] - enyhítéséhez erősebb fájdalomcsillapítóra van szükség [25].

Eredményeink alapján pozitív kapcsolat van az ante és postpartum depresszió között, vagyis az antepartum depresszió szintje előre jelezheti a postpartum depreszszió kialakulását Leigh és Milgrom vizsgálatához [23] hasonlóan. Ennek hátterében állhat, hogy a várandósság egy jelentős életesemény, amely komoly változásokat hozhat, újfajta stresszorokkal találkoznak a párok, még akkor is, ha már van gyermekük; sőt egy már meglévő gyermekről gondoskodni fokozó tényező lehet [27]. Egyes megküzdési módok kevésbé adaptívak másokkal szemben [28], így akik csak ezeket tudják alkalmazni, azok sérülékenyebbek a depresszióval szemben, és mivel a gyermekvállalás, annak stresszfaktorai hosszú távon fennállnak, a lehangoltság tartóssá tud válni.

Figyelembe véve az eredményeket, valamint azon tapasztalatunkat, hogy a várandósok és az édesanyák nem merik felvállalni nehézségeiket, sokszor a környezetüktől sem tudnak vagy mernek segítséget kérni, megállapíthatjuk, hogy fontos a szürés, hiszen ennek segítségével a patológiás hangulatváltozásokat már a kezdeti fázisában észlelhetjük, így korábban van lehetőség a megfelelő segítség biztosítására. A korán elkezdett pszichológiai intervenció segíthet csökkenteni a depresszív tüneteket, ezzel elkerülhetővé válik a későbbiekben a major depresszió, illetve egyéb szövődmények kialakulása, mint az alacsony születési súly, így a pszichológiai intervenció hozzájárulhat a normális születési súlyhoz.

A jelenlegi vizsgálat korlátja az elemszám: a teljes mintanagyság megfelelő, azonban kevesen töltötték ki ahhoz képest mind a négyszer a kérdőívet, illetve egyes alcsoportok elemszámai jelentősen eltérnek. A jelen adatok nem mutatják külön a kezelt és kezeletlen betegek statisztikáját, ezen adatok feldolgozása folyamatban van. Emellett a jövőben tervezzük vizsgálni a depresszív pontoknak többek között a koraszüléssel, gestatiós diabetesszel, praeeclampsiával való kapcsolatát is.

Anyagi támogatás: A közlemény megírása anyagi támogatásban nem részesült.

Szerzői munkamegosztás: H. E. A.: A kézirat megszövegezése, a hipotézisek kidolgozása, az adatok bevitele és elemzése. T. A.: A hipotézisek kidolgozása, az adatok bevitele és elemzése, a kézirat átnézése, szövegezése. B. F. V.: A vizsgálat lefolytatása. N. G.: Az elkészült kézirat szülészeti lektorálása. A kézirat végleges változatát valamennyi szerző elolvasta és jóváhagyta.

Érdekeltségek: A szerzőknek nincsenek érdekeltségeik. 


\section{Köszönetnyilvánítás}

Szeretnénk megköszönni Bodrogi Nikolettnek az adatgyưijtésben nyújtott segítségét. Emellett szeretnénk köszönetet mondani Dr. Pál Attila professzor úrnak, aki a szűrőprogram bevezetését és múködését mindvégig támogatta.

\section{Irodalom}

[1] Bödecs, T.: Negative effects and possible mechanisms of antenatal depression, anxiety and self-esteem on neonatal outcomes. PhD Thesis. [A várandósság alatti depresszió, szorongás és önértékelés neonatális kimenetelekre gyakorolt negatív hatásainak vizsgálata, és a lehetséges mechanizmusok feltárása. PhD-tézis.] Pécsi Tudományegyetem, Egészségtudományi Kar, 2010. Available from: http://ltsp.etk.pte.hu/portal/wp/File/Doktoriiskola/Tezisfuzetek/Ertekezes_BodecsTamas.pdf [Hungarian]

[2] Kopp, M., Szedmák, S., Lőke, J., et al.: The prevalence of depressive symptoms and its relevance in the health care in the Hungarian population. [A depressziós tünetegyüttes gyakorisága és egészségügyi jelentősége a magyar lakosság körében.] Lege Artis Med., 1997, 7(3), 136-144. [Hungarian]

[3] Kopp, M., Skrabski, Á.: Men's and women's health conditions in Hungary. In: Nagy, I., Pongrácz, T. (eds.): Role changes. A report of men's and women's situation, 2009. [Nők és férfiak egészségi állapota Magyarországon. In: Nagy, I., Pongrácz, T. (szerk.): Szerepváltozások. Jelentés nők és férfiak helyzetéről. 2009.] TÁRKI és Szociális és Munkaügyi Minisztérium, Budapest, 2009, 117-136. [Hungarian]

[4] Bowen, A., Muhajarine, N.: Antenatal depression. Can. Nurse, 2006, 102(9), 26-30.

[5] Skrabski, Á., Kopp, M., Rózsa, S., et al.: Life meaning: An important correlate of health in the Hungarian population. Int. J. Behav. Med., 2005, 12(2), 78-85.

[6] Cox, J. L., Holden, J. M., Sagovsky, R.: Detection of postnatal depression. Development of the 10-item Edinburgh Postnatal Depression Scale. Br. J. Psychiatry, 1987, 150, 782-786.

[7] Töreki, A., Andó, B., Keresztúri, A., et al.: The Edinburgh Postnatal Depression Scale: Translation and antepartum validation for a Hungarian sample. Midwifery, 2013, 29(4), 308-315.

[8] Töreki, A., Andó, B., Dudas, R. B., et al.: Validation of the Edinburgh Postnatal Depression Scale as a screening tool for postpartum depression in a clinical sample in Hungary. Midwifery, 2014 $30(8), 911-918$.

[9] Töreki, A., Andó, B., Kozinszky, Z., et al.: Perinatal psychopathologies at the University of Szeged, Department of Obstetrics and Gynaecology. [Perinatális pszichopatológiák a szegedi Szülészeti és Nőgyógyászati Klinikán.] Magyar Nőorvosok Lapja, 2013, 76(5), 6-12. [Hungarian]

[10] Töreki, A., Baloghné, F. V., Szenti, Z., et al.: The psychological screening process in the maternal care system. [A pszichológiai szűrés megjelenése a várandósgondozásban.] Magyar Nőorvosok Lapja, 2014, 77(6), 12-15. [Hungarian]

[11] Dudas, R. B., Csatordai, S., Devosa, I., et al.: Obstetric and psychosocial risk factors for depressive symptoms during pregnancy. Psychiatry Res., 2012, 200(2-3), 323-328.

[12] Kozinszky, Z., Dudas, R. B., Csatordai, S., et al.: Social dynamics of postpartum depression: a population-based screening in South-Eastern Hungary. Soc. Psychiatry Psychiatr. Epidemiol. 2011, 46(5), 413-423.

[13] Töreki, A.: Psychosocial risk factors and screening options for perinatal psychopathologies. PhD Thesis. Department of Ob- stetrics and Gynaecology, Albert Szent-Györgyi Medical Center, University of Szeged, Szeged, 2012. [A perinatális pszichopatológiák kialakulását elősegítő pszichoszociális faktorok és szűrési lehetőségeik. PhD-tézis.] Szegedi Tudományegyetem, SzentGyörgyi Albert Klinikai Központ, Szülészeti és Nőgyógyászati Klinika, Szeged, 2012. Available from: http://doktori.bibl. u-szeged.hu/1626/3/Toreki_Annamaria_doktori_disszert $\%$ C3\%Alci\%C3\%B3_PDF.pdf [Hungarian]

[14] Török, Zs.: Psychiatric disorders associated with childbearing, especially the field of the maternity blues. PhD-Thesis. [Szüléshez társuló pszichiátriai zavarok, különös tekintettel a gyermekágyi lehangoltság kérdéskörére. PhD-tézis]. Humán Bölcsészettudományok Doktori Iskola, Debreceni Egyetem, Debrecen, 2009. Available from: https://dea.lib.unideb.hu/dea/bitstream / handle $/ 2437 / 81696 /$ ertekezes.pdf? sequence $=5$ \&is Allowed $=\mathrm{y}$ [Hungarian]

[15] Lee, A. M., Lam, S. K., Sze Mun Lau, S. M.., et al.: Prevalence, course, and risk factors for antenatal anxiety and depression. Obstet. Gynecol., 2007, 110(5), 1102-1112.

[16] Jesse, D. E., Seaver, W., Wallace, D. C.: Maternal psychosocial risks predict preterm birth in a group of women from Appalachia. Midwifery, 2003, 19(3), 191-202.

[17] Rabman, A., Bunn, J., Lovel, H., et al.: Association between antenatal depression and low birthweight in a developing country. Acta Psychiatr. Scand., 2007, 115(6), 481-486.

[18] Gemeay, E. M., Moawed, S. A., Mansour, E. A., et al.: The association between diabetes and depression. Saudi Med. J., 2015, 36(10), 1210-1215.

[19] Räikkönen, K., Pesonen, A. K., Kajantie, E., et al.: Length of gestation and depressive symptoms at age 60 years. Br. J. Psychiatry, 2007, 190(6), 469-474.

[20] Picchioni, M., Murray, R. M.: Schizophrenia. BMJ, 2007, 335(7610), 91-95.

[21] Chibwesha, C. J., Zanolini, A., Smid, M., et al.: Predictors and outcomes of low birth weight in Lusaka, Zambia. Int. J. Gynaecol. Obstet., 2016, 134(3), 309-314.

[22] Barker, D. J., Osmond, C., Forsén, T. J., et al.: Trajectories of growth among children who have coronary events as adults. N. Engl. J. Med., 2005, 353(17), 1802-1809.

[23] Leigh, B., Milgrom, J.: Risk factors for antenatal depression, postnatal depression and parenting stress. BMC Psychiatry, 2008, 8 , 24.

[24] Chung, T. K., Lau, T. K., Yip, A. S., et al.: Antepartum depressive symptomatology is associated with adverse obstetric and neonatal outcomes. Psychosom. Med., 2001, 63(5), 830-834.

[25] Andersson, L.: Implications of psychiatric disorders during pregnancy and the postpartum period - A population-based study. Umeå University, Sweden, Print \& Media, Umeå, 2004.

[26] Greden, J. F.: Physical symptoms of depression: unmet needs. J. Clin. Psychiatry, 2003, 64(7), 5-11.

[27] Divney, A., Gordon, D., Magriples, U., et al.: Stress and behavioral risk among young expectant couples. J. Adoles., 2016, 53, 3444.

[28] Peterson, B. D., Newton, C. R., Rosen, K. H., et al.: The relationship between coping and depression in men and women referred for in vitro fertilization. Fertil. Steril., 2006, 85(3), 802-804.

(Hompoth Emőke Adrienn,

Szeged, Semmelweis u. 1., 6725 e-mail: hompothemoke@gmail.com) 